\title{
Van minimum, tekort en meerwaarde
}

\section{Een vergelijking tussen de grondwettelijke bescherming van grondrechten en de bescherming op grond van het EVRM}

\author{
Aernout Nieuwenhuis en Laurens Dragstra*
}

\section{Inleiding}

\section{I.I Grondrechten in de Grondwet}

De eerste Nederlandse Grondwet van I8I4 kende slechts een enkel grondrecht. Zo legde artikel 135 de vrijheid van openbare godsdienstoefening vast. Reeds in de Grondwet van I8I5 werden - op aandrang van de Belgen - de vrijheid van drukpers, de onschendbaarheid van de woning, de bescherming van de eigendom en het recht van petitie toegevoegd. In 1848 volgden onder meer het briefgeheim en de vrijheid van vereniging en vergadering en in 1917 werd het algemeen (mannen)kiesrecht vastgelegd, gelijktijdig met de gelijke bekostiging van openbaar en bijzonder lager onderwijs. ${ }^{\mathrm{I}}$

Sinds 1983 opent de Grondwet met een apart hoofdstuk gewijd aan de grondrechten. Daarin vinden we naast de reeds genoemde rechten onder meer het discriminatieverbod (artikel I) en het recht op bescherming van de persoonlijke levenssfeer (artikel ro). De klassieke grondrechten zijn aangevuld met een aantal sociale grondrechten als de zorg van de overheid voor bevordering van voldoende werkgelegenheid (artikel I9) en voor bescherming en verbetering van het leefmilieu (artikel 2I). ${ }^{2}$ Deze sociale grondrechten zijn in het algemeen niet vastgelegd als waarborgnormen of 'subjectieve rechten', maar als belangen waarmee rekening dient te worden gehouden bij de formulering van het beleid.

Afgezien van het Statuut, dat de relatie tussen Nederland, Aruba en de Nederlandse Antillen juridisch vormgeeft en waarin niet of nauwelijks grondrechten zijn vastgelegd, staat de Grondwet bovenaan de nationale regelhiërarchie. Overige regelingen, waaronder wetten in formele zin, en uitvoeringsbesluiten dienen derhalve in overeenstemming te zijn met de grondrechtelijke normen in de Grondwet. Daar dient onmiddellijk aan toegevoegd te worden dat de Nederlandse rechter wetten in

\footnotetext{
* Aernout Nieuwenhuis is universitair hoofddocent staats- en bestuursrecht en Laurens Dragstra is docent staats- en bestuursrecht aan de Universiteit van Amsterdam.

I. Zie voor dit alles onder meer Van der Pot 2006, p. I36-I54 en Kortmann 2008, p. 90-93.

2. Aanhangig is een initiatiefwetsvoorstel om de zorgplicht van artikel 2I Grondwet uit te breiden tot het welzijn van dieren. Zie Kamerstukken II 2006/07, 30 900, nr. I-2.
} 
formele zin niet mag toetsen aan de Grondwet. Artikel I20 Grondwet bepaalt dat de rechter niet treedt in de grondwettigheid van wetten. ${ }^{3}$

Het artikel maakt daarmee duidelijk dat de bescherming die de rechter de burger kan bieden minimaal is wanneer de beperking van diens grondwettelijke grondrechten in een formele wet vervat is. Het is aan de wetgever zelf om te beoordelen of de wet in formele zin in overeenstemming is met deze grondrechten. De rechter - iedere rechter - kan lagere regelingen dan de formele wet wél toetsen aan de Grondwet. Artikel 120 heeft uitsluitend betrekking op wetten die door regering en Staten-Generaal gezamenlijk zijn vastgesteld volgens de procedure van artikel $8 \mathrm{I}$ e.v. Grondwet.

\section{I.2 Grondrechten in het EVRM}

$\mathrm{Na}$ de Tweede Wereldoorlog is de bescherming van grondrechten hoog op de internationale en Europese agenda komen te staan. Dat blijkt onder meer uit de totstandkoming van verdragen als het IVBPR, het IVESCR, het EVRM en het ESH. De bepalingen van deze verdragen kunnen in de Nederlandse rechtsorde een belangrijke rol spelen. Op grond van artikel 93 Grondwet hebben een ieder verbindende bepalingen van verdragen en van besluiten van internationale organisaties namelijk verbindende kracht in de Nederlandse rechtsorde nadat zij zijn bekendgemaakt. Artikel 94 Grondwet voegt daaraan toe dat de rechter nationale wettelijke voorschriften buiten toepassing dient te laten indien de toepassing daarvan onverenigbaar is met een ieder verbindende bepalingen. ${ }^{4}$ De rechter - en dat wil wederom zeggen: elke rechter - is daarmee bevoegd om deze voorschriften op hun verdragsrechtelijke rechtmatigheid te toetsen. ${ }^{5}$ Met de term 'wettelijke voorschriften' worden alle nationale regelingen bedoeld. Daaronder vallen de Grondwet, de wet in formele zin en lagere regelingen als algemene maatregelen van bestuur en provinciale en gemeentelijke verordeningen.

Verdragen die bepalingen bevatten die afwijken van de Grondwet of daartoe nopen dienen wél in beide kamers van de Staten-Generaal met een meerderheid van twee derden van de uitgebrachte stemmen te worden goedgekeurd (artikel 9I lid 3 Grondwet). Het oordeel over de vraag of een verdrag van de Grondwet afwijkt en of de voorgeschreven procedure is gevolgd, is onttrokken aan de rechter. Artikel I20 Grondwet legt niet alleen het eerder genoemde verbod van toetsing van formele wetten aan de

3. Artikel I2o bepaalt voorts dat de rechter niet treedt in de grondwettigheid van verdragen. Zie hieronder.

4. Zie voor het begrip 'een ieder verbindend' onder meer Fleuren 2004.

5. Voor ontvankelijkheid in Straatsburg dient de vermeende schending in elk geval 'in substance' in de nationale procedure te zijn aangevoerd, EHRM 15 januari I996, Sadik v. Greece: 'It normally requires also that the complaints intended to be made subsequently at Strasbourg should have been made to those same courts, at least in substance and in compliance with the formal requirements and time-limits laid down in domestic law (see the Cardot v. France judgment of I9 March I99I, Series A no. 200, p. I8, para. 34).' 
Grondwet vast, maar bepaalt ook dat de rechter niet in de grondwettigheid van verdragen treedt. ${ }^{6}$

Het is uiteindelijk aan de rechter om de belangrijke vraag te beantwoorden welke verdragsbepalingen een ieder verbindend zijn. ${ }^{7}$ Als aanwijzingen ontbreken dat de verdragspartijen zijn overeengekomen dat aan een bepaling die werking wel of juist niet mag worden toegekend, is naar het oordeel van de Hoge Raad enkel de inhoud van de bepaling zelf beslissend: verplicht deze de Nederlandse wetgever tot het treffen van een nationale regeling met bepaalde inhoud of strekking, of is deze van dien aard dat de bepaling in de nationale rechtsorde zonder meer als objectief recht kan functioneren $?^{8}$

Verdragsbepalingen waarin klassieke grondrechten vastliggen, zullen over het algemeen aan dit criterium voldoen. De materiële bepalingen van het EVRM en de bijbehorende protocollen kunnen dan ook in beginsel alle als een ieder verbindende bepalingen worden beschouwd. Enige onduidelijkheid bestaat er over bepaalde aspecten van artikel 6 en I3 EVRM, met name wanneer deze tot een uitbreiding van de rechtsmacht van de rechter zouden moeten leiden. ${ }^{9}$ Bepalingen van verdragen, waarin sociale grondrechten vastliggen, zullen over het algemeen verplichten tot het treffen van regelingen en dus niet een ieder verbindend zijn. Hierop zijn echter wel uitzonderingen. ${ }^{\text {IO }}$ Bovendien kan de rechter verdragsbepalingen inhoudende sociale grondrechten wel degelijk in zijn overwegingen betrekken, zonder daaraan te toetsen. ${ }^{\text {II }}$

Een verdragsbepaling is in beginsel óf een ieder verbindend óf niet. In het verleden heeft de Centrale Raad van Beroep uitdrukkelijk de mogelijkheid opengelaten dat het antwoord op de vraag of een verdragsbepaling een ieder verbindend is mede afhankelijk is van de casus waarop deze toegepast zou moeten worden. ${ }^{12}$ De CRvB is

6. Artikel 9i lid 3 Grondwet en artikel I20, tweede deel, Grondwet zijn in 1956 in samenhang in de Grondwet opgenomen. Zie uitgebreid Fleuren 2004, p. I63 e.v., ook over de onenigheid in de literatuur over de positie van een in het geheel niet door het parlement goedgekeurd verdrag.

7. Dat wil niet zeggen dat hij geen rekening zou kunnen houden met bijvoorbeeld de opvatting van de wetgever zoals die uit de memorie van toelichting bij de goedkeuringswet naar voren komt. Zie bijvoorbeeld HR 20 april I990, NJ I992, 636.

8. HR 30 mei I986, NJ I986, 688; HR I8 april I995, NJ I995, 6r9.

9. Zie Barkhuysen e.a. 2000, p. 330. Deze notie was gebaseerd op HR I8 februari I986, NJ I987, 62 en HR I9 april I998, NJ I998, 474. De scheidend president van de Hoge Raad, Martens, heeft echter verduidelijkt dat de overwegingen van de Hoge Raad op de uitleg van genoemde bepalingen en niet op de doorwerking in de Nederlandse rechtsorde zagen, zie Martens 2000a, p. 756, noot 67. In dat geval kan op grond van deze arresten kan dus niet tot een dergelijke 'gedeeltelijke een ieder verbindendheid' worden geconcludeerd. Zie hierover ook Fleuren 2004, p. 270. Barkhuysen 2004, p. 46 is door de verduidelijking van Martens echter niet overtuigd. Mogelijkerwijs is de oplossing dat de bepalingen wel in hun geheel een ieder verbindend zijn maar uitbreiding van de rechtsmacht de rechtsvormende taak van de rechter te buiten gaat.

Io. Bijv. CRvB 29 mei r996, AB I996, 50 I.

II. Zie bijvoorbeeld HR 7 mei I993, NJ I995, 259 waarin artikel 7 IVESCR, hoewel niet rechtstreeks werkend, toch een zekere rol speelt. De Hoge Raad overweegt dat 'de waarborg van een gelijke beloning voor gelijke arbeid in het IVESC wel een doelstelling (is) waarnaar gestreefd dient te worden. (...) Hiermee zou niet stroken om al te snel aan te nemen dat voor een beloningsverschil dat het uitgangspunt van een gelijke beloning voor gelijke arbeid doorkruist, een redelijke en objectieve rechtvaardiging voorhanden is.'

I2. CRvB I6 februari $1989, A B$ I989, 164 . 
echter op deze benadering teruggekomen. ${ }^{\mathrm{I} 3}$ Daarmee lijkt de opvatting dat veel verdragsbepalingen in het ene geval een ieder verbindend kunnen zijn en in een ander geval niet, een zachte dood te zijn gestorven.

\section{I.3 Vraagstelling: de onderlinge verhouding}

Uit het voorgaande is duidelijk dat de Nederlandse rechter in beginsel zowel uit de Grondwet als uit het EVRM kan putten bij de bescherming van grondrechten. In dit preadvies staat de vraag naar de onderlinge verhouding tussen die twee vormen van bescherming centraal. De beantwoording ervan stuit onmiddellijk op de kloof die gaapt tussen het toetsingsverbod (artikel I20 Grondwet) en het 'toetsingsgebod' (artikel 94 Grondwet). Ten aanzien van de grondwettelijke bescherming zal de rechter zich in veel gevallen neer moeten leggen bij de uitleg van de grondwetsbepalingen door de wetgever. Bij de verdragsrechtelijke bescherming prevaleert zijn oordeel in beginsel juist boven dat van de wetgever.

De ongelijke rol die de grondrechtelijke grondrechten enerzijds en de verdragsgrondrechten anderzijds bij de Nederlandse rechter spelen, kleurt alle meer specifieke vraagstukken die betrekking hebben op hun onderlinge verhouding, zoals de mogelijkheid van wisselwerking, aanvullende bescherming en botsing. Om die reden is er in het preadvies eerst gerede aandacht voor de achtergrond van het toetsingsverbod, dat niet op zichzelf blijkt te staan, maar een element vormt van de verhouding tussen de wetgevende en de rechterlijke macht binnen het Nederlandse constitutionele bestel. Bovendien lijkt deze verhouding invloed te hebben op de bescherming die de Nederlandse rechter aan de in het EVRM vastgelegde grondrechten kan bieden. Dat blijkt in het bijzonder bij beantwoording van de vraag of de Nederlandse rechter een verdergaande interpretatie van de bepalingen van het EVRM kan geven dan het EHRM doet, en bij beantwoording van de vraag of de rechter door rechtsvorming zelf in een rechtstekort kan voorzien of die rechtsvormende taak aan de wetgever moet laten. Mede in dat verband is het relevant dat de Nederlandse rechter de wetgever geen opdracht tot wetgeving kan geven.

\section{I.4 Opbouw preadvies}

In de paragraaf na deze inleiding staat de waarborging van de grondwettelijke grondrechten centraal (2). Daarin komt naast het toetsingsverbod en de achtergronden ervan ook het grondwettelijke systeem van clausulering aan bod. Op grond van beide onderdelen kan worden vastgesteld welke betekenis de grondwettelijke grondrechten bij de Nederlandse rechter hebben. De volgende paragraaf staat in het teken van het EVRM (3). In deze inleiding is al vastgesteld dat de verdragsbepalingen in de Nederlandse rechtsorde verbindende kracht hebben. In deze paragraaf zal worden ingegaan op de ontwikkeling van de jurisprudentie van het EHRM en op de vraag naar de doorwerking in de Nederlandse rechtsorde. Daarna is er speciaal aandacht voor de vraag of de Nederlandse rechter op grond van het EVRM een grotere

I3. CRvB I7 december I99I, RSV I992, I64; vgl. in dezen HR 22 april I990, NJ I992, 636. 
bescherming mag bieden dan het EHRM doet en voor de vraag in hoeverre de rechter bij het voldoen aan bepaalde verdragsverplichtingen op de grenzen van zijn rechtsvormende taak stuit.

Uit de paragrafen over de bescherming op grond van de Grondwet en het EVRM blijkt reeds de onderlinge verhouding. De vierde paragraaf zal expliciet op een aantal specifieke punten ingaan: de mogelijkheid van wisselwerking, aanvullende bescherming, meerwaarde en botsing (4). De vraag in hoeverre de constitutionele positie van de rechter invloed heeft op de bescherming die hij biedt op grond van het EVRM, wordt eveneens besproken. Enkele slotopmerkingen sluiten het geheel af (5).

In de loop van het preadvies zal een paar maal aandacht worden besteed aan het aanhangige initiatiefvoorstel tot wijziging van de Grondwet dat - gespreide - toetsing van formele wetten aan de klassieke grondrechtsbepalingen mogelijk wil maken. Dit voorstel, dat in eerste lezing bij de Eerste Kamer aanhangig is, ${ }^{\mathrm{I}}{ }^{\mathrm{b}} \mathrm{brengt}$ namelijk bij uitstek de vraag met zich mee wat de (mogelijke) meerwaarde van een dergelijke toetsingsmogelijkheid is.

\section{Bescherming van grondwettelijke grondrechten}

\section{I Toetsingsverbod, trias politica en de plaats van de rechter}

\section{Geschiedenis van het toetsingsuerbod}

Het toetsingsverbod heeft een lange geschiedenis. In I 848 werd het in de Grondwet opgenomen met de bewoordingen 'de wetten zijn onschendbaar', maar met deze opname werd blijkens de parlementaire geschiedenis niets anders bedoeld dan de bestaande rechtstoestand in de Grondwet vast te leggen. ${ }^{15}$ Het voorstel voor een toetsingsverbod was afkomstig van de toenmalige regering, en niet van de door Thorbecke voorgezeten staatscommissie tot herziening van de Grondwet. ${ }^{\mathrm{I} 6}$ Thorbecke heeft het voorstel dan ook zwaar bekritiseerd. ${ }^{17}$ Ook in de anderhalve eeuw daarna zijn vanuit de literatuur en vanuit de politiek regelmatig voorstellen gedaan het toetsingsverbod geheel of gedeeltelijk op te heffen.

De Staatscommissie Cals/Donner, wier voorstellen aan de basis lagen van de grondwetsherziening van $1_{983}$, stond op het standpunt dat de rechter wetten waarvan de toepassing niet verenigbaar was met de grondwettelijke grondrechten buiten toepassing zou moeten (kunnen) laten. ${ }^{18}$ Naast het argument van meer rechtsbescherming voor de burgers in concrete gevallen, werd door de commissie gewezen op de merkwaardige situatie dat de rechter sinds 1953 wetten mocht toetsen aan

I4. Kamerstukken I 2004/05, 28 33I, A.

I5. Vóór I848 schijnt, in lijn met de bedoelingen van de grondwetgever van I8I5, de vraag of de rechter formele wetten mocht toetsen aan de Grondwet niet aan de orde te zijn geweest, aldus Van der Pot 2006, p. 203. Uitgebreid over de periode vóór I848: Van Houten I997, p. 27-32.

I6. Van der Pot 2006, p. I43-I45.

I7. Zie o.a. Kortmann 2005, p. 374-375; Van Houten I997, p. 35-37.

I8. Daarbij sloot de Staatscommissie aan bij de in april I966 verschenen 'Proeve van een nieuwe Grondwet', afkomstig van de Afdeling Grondwetszaken van het Ministerie van Binnenlandse Zaken en een aantal niet-ambtelijke staatsrechtdeskundigen. 
een ieder verbindende bepalingen van verdragen (zie thans artikel 94 Grondwet), maar niet aan de Nederlandse Grondwet. ${ }^{\text {I9 }}$

Ondanks deze positieve adviezen heeft de grondwetgever bij de algehele grondwetsherziening van 1983 aangehaakt bij het standpunt van de minderheid van de genoemde Staatscommissie en vastgehouden aan het toetsingsverbod. De formulering ervan werd wel enigszins aangepast: 'de wetten zijn onschendbaar' werd veranderd in 'de rechter treedt niet in de grondwettigheid van wetten'. De discussie over de wenselijkheid van rechterlijk toetsingsrecht was daarmee overigens geenszins verstomd. In I99I mengde ook de Hoge Raad zich in de discussie door de regering te adviseren het toetsingsverbod op te heffen voor wat betreft een limitatief opgesomd aantal grondrechten. De Hoge Raad toonde zich een voorstander van zogenaamde diffuse of gespreide toetsing, waarbij iedere rechter de bevoegdheid heeft wetten buiten toepassing te laten wegens strijd met de genoemde grondrechten. ${ }^{20} \mathrm{Op}$ II november 1997 adviseerde de Hoge Raad de regering opnieuw en daarbij herhaalde hij zijn eerder ingenomen standpunt pro gedeeltelijke opheffing van het toetsingsverbod. De door de regering ingestelde 'zware' Commissie Grondrechten in het digitale tijdperk (Commissie-Franken) toonde zich in grote meerderheid eveneens voorstander van wijziging van artikel 120 Grondwet. ${ }^{2 \mathrm{I}}$ Tenslotte uitte in 2002 ook het tweede kabinet-Kok een lichte voorkeur voor toetsing door de rechter aan klassieke grondrechten in een systeem van gespreide toetsing. ${ }^{22}$

Enige dagen voordat het genoemde kabinet zijn voorkeur uitsprak in de nota 'Constitutionele toetsing van formele wetten' had het Tweede-Kamerlid F. Halsema (GroenLinks) een initiatiefwetsvoorstel aanhangig gemaakt tot wijziging van artikel I20 Grondwet. Dit voorstel voegt een tweede lid aan artikel I20 toe dat bepaalt dat wetten niettemin geen toepassing vinden wanneer die toepassing niet verenigbaar is met de in dit artikellid opgesomde grondwetsbepalingen. Het gaat daarbij om grondrechten die een 'subjectief recht' toekennen, derhalve voornamelijk om de 'klassieke grondrechten'. Het voorstel-Halsema is momenteel in eerste lezing bij de Eerste Kamer aanhangig. ${ }^{23}$ Deze heeft het voorbereidend schriftelijk onderzoek inmiddels afgerond en zal waarschijnlijk in het najaar beginnen met de plenaire behandeling.

\section{Omvang toetsingsuerbod}

Het toetsingsverbod van artikel I20 Grondwet ziet niet alleen op de mogelijke strijdigheid tussen de inhoud van een wettelijke bepaling en een grondwettelijke norm. ${ }^{24}$ Ook het oordeel of een wet overeenkomstig de in de Grondwet vastgelegde procedures tot stand is gekomen, is voorbehouden aan de wetgever. De Hoge Raad heeft een onderscheid tussen materiële en formele toetsing afgewezen, onder meer in het arrest Van den Bergh/Staat. ${ }^{25}$ In deze zaak ging het om een voormalig TweedeKamerlid, tevens hoogleraar staatsrecht, dat geconfronteerd werd met een korting

I9. Van der Pot 2006, p. 204-205; Kamerstukken II 2002/03, 28 33I, nr. 9, p. 3-5.

20. Gepubliceerd in NJCM-bulletin I992, p. 243-259.

2I. Commissie-Franken 2000, p. 49-50.

22. Kamerstukken II 200I/02, 28 355, nr. 2, p. 8.

23. Zie Kamerstukken I 2004/05, 28 33I, A.

24. Zie bijvoorbeeld HR in februari I986, NJ I986, 673.

25. HR 27 januari I96I, NJ I963, 248. 
op het pensioen waarop hij als gewezen lid van de Tweede Kamer recht had. Een wet waarin een dergelijke korting werd doorgevoerd kon volgens de Grondwet alleen met de stemmen van twee derden van het aantal leden van de beide Kamers worden aangenomen. Van den Bergh betoogde dat niet kon worden vastgesteld dat dit gebeurd was, nu geen hoofdelijke stemming had plaatsgevonden. De 'wet' zou daarom rechtskracht missen.

De Hoge Raad ging niet mee in dit betoog. Hij oordeelde dat de grondwetgever het oordeel over de vraag naar de uitleg van grondwetsbepalingen uitsluitend aan de wetgever heeft willen doen toekomen. Daarbij moet volgens de Hoge Raad geen onderscheid gemaakt worden tussen het toetsen of de inhoud van een wet in overeenstemming met de Grondwet is en het toetsen of bij de totstandkoming van de wet de juiste procedure in acht is genomen. In beide gevallen gaat het immers om het uitleggen van grondwettelijke bepalingen, een uitleg die de Grondwet nu juist bij uitsluiting aan de wetgever opdraagt. ${ }^{26}$

In het Harmonisatiewetarrest uit $1989^{27}$ kwam de vraag aan de orde of de rechter formele wetten mag toetsen aan ongeschreven fundamentele rechtsbeginselen. ${ }^{28}$ De tekst van artikel I20 Grondwet spreekt alleen over toetsing aan de Grondwet en sluit strikt genomen een dergelijke toetsing niet uit. De Hoge Raad merkt op dat er weliswaar zeer veel argumenten voor de toetsing aan ongeschreven rechtsbeginselen zijn te geven, maar dat deze toch moet worden afgewezen. ${ }^{29}$ Doorslaggevend voor hem is dat bij de grondwetsherziening van 1983 de vraag naar (gedeeltelijke) opheffing van het toetsingsverbod principieel is besproken in het parlement en ontkennend is beantwoord. Hoewel de nieuwe formulering van artikel I20 Grondwet de rechter méér lijkt toe te staan dan de oude ('de wetten zijn onschendbaar'), is van de zijde van de regering bij herhaling betoogd dat de nieuwe bepaling dezelfde strekking heeft als de oude, met als gevolg dat toetsing aan ongeschreven rechtsbeginselen

26. Wel mag de rechter in zoverre 'toetsen' dat het hem vrijstaat na te gaan of hij met een wet te maken heeft. Daarvoor kan hij de Handelingen van de beide Kamers raadplegen, alsmede onderzoeken of de wet bekrachtigd is door de Koning. Het standpunt van de Staten-Generaal dat de wet is aangenomen conform de grondwettelijke voorschriften heeft de rechter echter te respecteren: hij kan de wetgever op dit punt niet corrigeren.

27. HR I4 april I989, NJ I989, 469. De casus die leidde tot het genoemde arrest betrof een geding tussen de Landelijke Studentenvakbond en de Staat der Nederlanden over de zogenaamde Harmonisatiewet. Deze wet beperkte de inschrijvingsduur voor studenten tot maximaal zes jaar en bepaalde dat na deze periode het collegegeld werd verhoogd en de studiefinanciering werd stopgezet. De wet leidde ertoe dat veel studenten die een tweede opleiding volgden benadeeld werden: toen ze met de tweede studie begonnen, konden ze ervan uitgaan dat ze gedurende de gehele studie studiefinanciering zouden ontvangen. Nu zou de studiefinanciering echter halverwege worden stopgezet. De studenten beriepen zich op het rechtszekerheidsbeginsel als ongeschreven rechtsbeginsel en op de rechtszekerheid zoals verankerd in artikel 43 Statuut.

28. Tevens kwam de vraag aan bod of de rechter formele wetten zou mogen toetsen aan het Statuut voor het Koninkrijk, het document waarin de relatie tussen Nederland, de Nederlandse Antillen en Aruba juridisch is vormgegeven. De Hoge Raad wees ook deze toetsing af.

29. Een soortgelijk oordeel kon reeds uit HR I6 mei I986, NJ I987, 25I worden afgeleid, al was de Hoge Raad daar niet geheel duidelijk. Zie ook Hof Den Haag I3 maart I985, NJ I985, 263, waarin met een beroep op de grondwetsgeschiedenis toetsing aan ongeschreven rechtsbeginselen wordt afgewezen. 
niet is toegestaan..$^{30}$ De Hoge Raad voegt daaraan toe dat een ruim toetsingsverbod 'wezenlijk is voor de traditionele plaats van de rechterlijke macht in ons staatsbestel'.

Interessant is dat het door de Hoge Raad uitgesproken toetsingsverbod diezelfde Hoge Raad er niet van weerhoudt om met zoveel woorden duidelijk te maken dat hij de Harmonisatiewet in strijd acht met het rechtszekerheidsbeginsel. ${ }^{3 \mathrm{I}}$ Klaarblijkelijk houdt het toetsingsverbod niet in dat de rechter in het geheel geen overweging mag wijden aan de rechtmatigheid van de wet. Een (stille) hint aan de wetgever is blijkbaar toegestaan. Het is de rechter echter verboden consequenties te verbinden aan vastgestelde gebreken, bijvoorbeeld door de wet buiten toepassing te laten. ${ }^{32}$ Interessant is voorts dat de Hoge Raad ook een reeks argumenten vóór toetsing aan ongeschreven rechtsbeginselen opsomt. ${ }^{33}$ Het is dan ook niet uitgesloten dat het college zijn standpunt ten aanzien van toetsing aan rechtsbeginselen ${ }^{34}$ ooit zal verlaten. Voorlopig lijkt het daar echter niet op: het verbod op een dergelijke toetsing is in 2000 en 2001 nog eens bevestigd. 35

\section{Ingrijpen in het wetgevingsproces en wetgevingsbevelen}

De rechter kan formele wetten dus niet toetsen aan de Grondwet en aan ongeschreven fundamentele rechtsbeginselen. Ook is het hem niet toegestaan te toetsen of de wet op de door de Grondwet voorgeschreven wijze tot stand is gekomen. In dit licht beschouwd hoeft het weinig verbazing te wekken dat de rechter ook niet snel geneigd is in het wetgevingsproces in te grijpen op het moment dat de wet nog 'in de mak' is en procederende burgers claimen dat Grondwet of rechtsbeginselen (drei-

30. Kortmann 2005 , p. 377 betwist dat de parlementaire geschiedenis op dit punt duidelijk is. Zijns inziens werd toetsing van de wet aan ongeschreven rechtsbeginselen niet geheel uitgesloten. Zie echter Van Houten I997, p. 59.

3. Zie r.o. 3.I van het arrest.

32. Vgl. Van Houten I997, p. 6r.

33. Zie r.o. 3.5 van het arrest.

34. Van toetsing van de wet zelf, waarbij haar verbindendheid in het geding is, moet de toetsing van de toepassing van wet aan algemene rechtsbeginselen worden onderscheiden. In 1978 aanvaardde de belastingkamer van de Hoge Raad 'dat onder omstandigheden strikte toepassing van de wet (...) in die mate in strijd kan komen met een of meer beginselen van behoorlijk bestuur, dat die toepassing achterwege dient te blijven', HR I2 april I978, AB I979, 262. Het optreden van de belastinginspecteur in deze zaak was weliswaar in overeenstemming met de wet, maar kwam in strijd met het vertrouwensbeginsel. Dat laatste beginsel moest volgens de Hoge Raad in deze zaak 'contra legem', oftewel tegen de wet in worden toegepast, met als gevolg dat de inspecteur de Successiewet niet mocht toepassen. Ook de studenten deden in hun zaak tegen de Harmonisatiewet een beroep op de contra legem jurisprudentie: als de wet zelf dan niet getoetst mocht worden aan ongeschreven rechtsbeginselen, dan gold volgens hen dat toepassing van de Harmonisatiewet het rechtszekerheidsbeginsel in die mate geweld aandeed, dan toepassing achterwege moest blijven. De Hoge Raad verwierp dit betoog mede omdat de studenten zich hadden beroepen op feiten en omstandigheden die door de wetgever bij het vaststellen van de Harmonisatiewet in de afweging betrokken waren. Hun betoog dat toepassing van de wet in strijd kwam met het rechtszekerheidsbeginsel kwam er daarom eigenlijk op neer dat de wet zelf in strijd was met dat beginsel. En toetsing van de wet aan ongeschreven beginselen is de rechter niet toegestaan, zodat de Hoge Raad het betoog wel moest verwerpen. Voor de toepassing van de contra legem leer is slechts ruimte wanneer de bezwaren tegen de toepassing van de wet niet te herleiden zijn tot bezwaren tegen de wet zelf. Zie Van Houten I995, p. 464; Van Houten I997, p. 89.

35. HR I4 april 2000, NJ 2000, 7I3; HR I6 november 200I, NJ 2002, 469. Zie tevens HR 23 december I992, BNB I993, I04. 
gen te) worden geschonden. Het ligt immers niet voor de hand dat de rechter de handelwijze van de wetgevende organen zou mogen beoordelen tijdens het wetgevingsproces als hij dat na afloop van het wetgevingsproces al niet mag. Lange tijd hebben met name lagere gerechten zich met deze kwestie beziggehouden. Uit hun uitspraken kan geen glashelder antwoord op de gestelde vraag gedestilleerd worden. Weliswaar werd in geen enkele zaak de vordering toegewezen, maar enkele rechters leken rechterlijk ingrijpen in extreme omstandigheden niet uit te sluiten. ${ }^{36}$

Het arrest Tegelen van de Hoge Raad uit 1999 heeft wat meer duidelijkheid verschaft. ${ }^{37}$ Het ging in deze zaak om het volgende: de gemeente Tegelen dreigde te worden samengevoegd met de grotere buurgemeente Venlo. Deze gemeentelijke herindeling lag zeer gevoelig. De Wet algemene regels herindeling stelt dat de provinciale organen, bij wie het initiatief voor een herindeling ligt, over een mogelijke herindeling overleg dienen te voeren met de betreffende gemeentebesturen voordat zij aan de verantwoordelijke bewindspersoon een herindelingsvoorstel doen. Vervolgens geschiedt de herindeling bij formele wet. De klacht van Tegelen kwam erop neer dat dit overleg niet kon worden gekwalificeerd als het 'open overleg' dat de Wet Arhi blijkens de wetsgeschiedenis eiste: gedeputeerde staten zou allang een definitief standpunt over de toekomst van Tegelen hebben.

De president van de Rechtbank Maastricht honoreerde de bezwaren van de gemeente en gelastte de provincie de besluitvorming rond de herindeling op te schorten totdat het wettelijke vereiste 'open overleg' had plaatsgevonden. Het Hof Den Bosch had dat vonnis vernietigd, enerzijds omdat het geen onrechtmatig handelen van de provincie vaststelde, anderzijds omdat het van oordeel was dat de burgerlijke rechter slechts een marginale bevoegdheid heeft ten aanzien van ingrijpen in het wetgevingsproces. Let wel: er was op het moment dat deze procedure begon nog niet eens sprake van een wetsvoorstel. ${ }^{38}$ Het ging om de procedure die daaraan voorafging (een voorfase) en om het naleven van de daarbij in acht te nemen wettelijke procedureregels. Gezien deze constatering lijkt het toetsingsverbod van artikel I2O Grondwet dus niet van toepassing te zijn.

Toch ziet de Hoge Raad geen mogelijkheden voor rechterlijk ingrijpen. Zijn redenering is als volgt: wijziging van de gemeentelijke indeling geschiedt bij formele wet. Als zo'n wet eenmaal tot stand gekomen is, dan komt aan de rechter niet het oordeel toe dat onrechtmatig is gehandeld doordat bij de voorbereiding en de behandeling van die wet terzake gegeven procedurevoorschriften zijn geschonden. De rechter moet het oordeel van de formele wetgever over de vraag of die voorschriften in acht zijn genomen respecteren. Met dit uitgangspunt verdraagt zich niet dat de rechter tijdens de procedure die uiteindelijk tot een formele wet leidt, wél zou kunnen oordelen dat procedurevoorschriften zijn geschonden en op grond van die vaststelling in het wetgevingsproces zou kunnen interveniëren. Dat zou immers tot gevolg hebben dat 'de vraag of procedurevoorschriften zijn geschonden en, zo ja, welke gevolgen daaraan moeten worden verbonden, in feite wordt onttrokken aan

36. Zie voor een overzicht van de lagere rechtspraak Van Houten I997, p. 68-73.

37. HR ig november I999, NJ 2000, I6o.

38. Dat werd op 6 januari 2000 ingediend, dus circa anderhalve maand na de uitspraak van de Hoge Raad. Zie Kamerstukken II I999/2000, 26 970, nr. I-2. 
de beoordeling door de formele wetgever, aan wie dit oordeel bij uitsluiting toekomt'. De Hoge Raad adviseert de gemeente vervolgens haar bezwaren aan de wetgever kenbaar te maken. Die moet dan maar uitmaken of er muziek in zit.

De uitspraak lijkt in het verlengde van artikel I20 Grondwet te liggen, ${ }^{39}$ ook al ging het om toetsing van een fase vóór het wetgevingsproces en om toetsing aan wettelijke procedurevoorschriften. De uitspraak lijkt tevens voort te bouwen op het reeds eerder besproken Van den Bergh/Staat. Interessant is voorts dat de Hoge Raad opmerkt dat als hij een oordeel geeft over de schending van procedurevoorschriften, de vraag of deze voorschriften geschonden zijn in feite wordt onttrokken aan beoordeling door de wetgever. Kennelijk ziet de Hoge Raad wel juridische ruimte voor de wetgever om van het rechterlijke oordeel af te wijken, maar acht hij het tegelijkertijd ondenkbaar dat dat ook daadwerkelijk zal gebeuren.

Tenslotte moet worden vermeld dat de Hoge Raad stelt dat in het midden kan blijven in hoeverre zijn oordeel anders zou zijn wanneer de zaak zou hebben gedraaid om strijd met een ieder verbindende bepalingen van verdragen, waaraan wetten ingevolge artikel 94 Grondwet wél mogen worden getoetst. Door rechterlijk ingrijpen in het wetgevingsproces niet principieel af te wijzen, lijkt de Hoge Raad hier de deur op een kier te zetten. In het arrest Waterpakt/Staat $4^{\circ}$ lijkt de deur echter onverbiddelijk in het slot te zijn gegooid. Het draaide in deze zaak om de implementatie van de zogenaamde Nitraatrichtlijn, een op I2 december I99I door de Raad van de EG vastgestelde richtlijn betreffende de bescherming van water tegen verontreiniging door nitraten uit agrarische bronnen (met name dierlijke mest). Uitvoering van deze richtlijn bleek voor Nederland een moeizaam proces. Nadat de Staat reeds tweemaal door de Europese Commissie in gebreke was gesteld, startten Waterpakt c.s. een procedure bij de burgerlijke rechter. Kort daarna werd Nederland opnieuw door de Europese Commissie in gebreke gesteld. Op 24 november 1999 oordeelde de Rechtbank Den Haag dat de Staat door nalatig te zijn bij de implementatie van de richtlijn onrechtmatig had gehandeld jegens de eisende partijen. De Staat werd veroordeeld om zodanige maatregelen te nemen dat werd gewaarborgd dat aan de gebruiksnorm voor dierlijke mest werd voldaan. Enkele maanden na het vonnis startte de Europese Commissie een inbreukprocedure tegen Nederland bij het Hof van Justitie (artikel 226 EG).

Bij arrest van 2 augustus 200 I vernietigde het Hof Den Haag het eerdere vonnis van de rechtbank. Het hof was het eens met de stelling van de Staat dat implementatie van de Nitraatrichtlijn alleen kon geschieden door het tot stand brengen van formele wetgeving, namelijk door wijziging van de Meststoffenwet of andere formele wetten. ${ }^{4 \mathrm{I}}$ Het dictum van de rechtbank kwam er dus op neer dat aan de Staat en bevel werd gegeven om formele wetgeving tot stand te brengen. Tot het geven van zo'n 'wetgevingsbevel' achtte het hof de rechter niet bevoegd. Het oordeelde 'dat het de rechter op grond van zijn staatsrechtelijke positie niet vrijstaat in het proces van formele wetgeving in te grijpen conform de strekking van deze vordering'. Deze

39. Zie bijvoorbeeld Drupsteen in diens noot onder HR ig november I999, AB 2000, 387 .

40. HR 2I maart 2003, NJ 2003, 69I.

4I. Een overweging die overigens op scherpe kritiek kan rekenen van annotator Koopmans in zijn noot onder HR 2I maart 2003, NJ 2003, 69I. 
rechtsoverweging werd zonder enig voorbehoud geformuleerd: het hof ziet klaarblijkelijk tegen rechterlijk ingrijpen in het wetgevingsproces principiële bezwaren, óók wanneer strijd met EG-recht wordt aangevoerd. Voor wat betreft de vraag of de Staat onrechtmatig had gehandeld door de richtlijn niet naar behoren uit te voeren hield het hof de zaak aan in afwachting van de uitspraak van het Hof van Justitie in de inbreukprocedure. ${ }^{42}$ Waterpakt c.s. stelden daarop beroep in cassatie in.

De Advocaat-General Langemeijer was van mening dat de rechtsoverweging van het hof te ruim geformuleerd was: zowel naar nationaal recht als naar EG-recht zouden wel degelijk mogelijkheden bestaan om de Staat een wetgevingsbevel te geven, zolang maar vaststond dat de wetgever geen enkele keuzeruimte meer had. De Hoge Raad verwerpt echter het cassatieberoep. Zijn redenering is als volgt: wetten in formele zin worden op grond van artikel 8I Grondwet vastgesteld door de regering en de Staten-Generaal gezamenlijk, waarbij de vraag of, wanneer en in welke vorm een wet tot stand zal komen, moet worden beantwoord op grond van politieke besluitvorming en afweging van de erbij betrokken belangen: 'De evenzeer op de Grondwet berustende verdeling van bevoegdheden van de verschillende staatsorganen brengt mee dat de rechter niet vermag in te grijpen in die procedure van politieke besluitvorming.' Volgens de Hoge Raad is de situatie niet anders wanneer het resultaat dat met de wetgeving moet worden bereikt en de termijn waarbinnen dat moet gebeuren helder voortvloeien uit een Europese richtlijn. Ook in dat geval kan de wetgever op grond van politieke overwegingen besluiten geen wetgeving tot stand te brengen en het te laten aankomen op een inbreukprocedure in Luxemburg. De rechter kan in zo'n situatie wel wettelijke bepalingen richtlijnconform uitleggen en eventueel een verklaring voor recht geven of schadevergoeding toekennen, maar een wetgevingsbevel behoort niet tot de mogelijkheden.

Volgens de Hoge Raad noopt het EG-recht niet tot een andere beslissing. Weliswaar vloeit uit de rechtspraak van het Luxemburgse Hof voort dat nationale rechters gehouden zijn de volle werking van het EG-recht te verzekeren, maar de Hoge Raad neemt aan dat deze taak slechts kan worden vervuld binnen het kader van de voor de rechter bestaande bevoegdheden en dat die bevoegdheden worden bepaald door het nationale recht. Kortom: nu die bevoegdheden naar nationaal recht niet bestaan - zie hierboven - bestaan ze naar EG-recht ook niet. De Hoge Raad volgde niet de suggestie van de Advocaat-Generaal om hierover prejudiciële vragen te stellen. Dat is jammer, want een uitspraak van het Hof van Justitie had uitsluitsel kunnen geven over de vraag of uit het Europese recht voor de rechter de bevoegdheid voortvloeit de Staat een bevel tot wetgeving te geven.

De lijn van het Waterpakt-arrest is in het arrest Stichting Faunabescherming/provincie Fryslân 43 bevestigd en zelfs nog wat verbreed. Het ging in deze zaak namelijk niet om formele wetgeving, maar om een provinciale verordening die in strijd zou zijn met de Vogelrichtlijn van 1979 en de Habitatrichtlijn van I992, alsmede met de Flora en Faunawet waarop zij was gebaseerd. De Faunabescherming had in kort

42. Zie daarvoor HvJEG 2 oktober 2003, NJ 2004, 474. Nederland werd volgens verwachting veroordeeld wegens het niet voldoen aan zijn uit de Nitraatrichtlijn voortvloeiende verplichtingen.

43. HR I oktober 2004, NJ 2004, 679. 
geding gevorderd dat de rechter de provincie zou bevelen de verordening in te trekken, maar noch de voorzieningenrechter, noch in hoger beroep het Hof Leeuwarden zagen daar enige grond of mogelijkheid voor. Voor de Hoge Raad is zonder belang dat het hier niet om formele wetgeving gaat: ook een bevel tot vaststelling, c.q. intrekking van een provinciale verordening wordt door het college gezien als 'een ongeoorloofd ingrijpen in de procedure van politieke besluitvorming en belangenafweging die is voorbehouden aan de gekozen vertegenwoordigers in de provinciale staten'. Deze zaak maakt wel duidelijk dat het in dit soort kwesties eigenlijk niet gaat om artikel 120 Grondwet, maar meer in het algemeen om de verdeling van bevoegdheden tussen de verschillende staatsorganen.

Concluderend kan gesteld worden dat er naast het toetsingsverbod een verbod op het ingrijpen in het wetgevingsproces lijkt te bestaan dat niet alleen op artikel I20 Grondwet kan worden gebaseerd, maar veeleer samenhangt met het staatsrechtelijk bestel, dat wil zeggen de wijze waarop in Nederland de trias politica is vormgegeven. Met dit stelsel verdraagt zich niet dat de rechter de wetgever op de vingers kijkt en zonodig tikt wanneer deze gedurende het proces van de wetgevende arbeid beweerdelijk fouten maakt. Ruimte voor correcties achteraf is er wel, uiteraard zolang het toetsingsverbod van artikel 120 daar niet aan in de weg staat. Maar bevelen tot wijziging, intrekking of niet-bekrachtiging van een wetsvoorstel of tot het überhaupt opstarten van het wetgevingsproces om een wet tot stand te brengen of een bestaande wet te wijzigen, dan wel in te trekken zitten er niet in. Daarbij is klaarblijkelijk niet van belang of door het handelen of nalaten van de wetgever regels van nationaal of internationaal recht geschonden zijn, en of de bekritiseerde wetgever op het centrale of het decentrale niveau opereert. Ondanks kritiek vanuit de literatuur houdt de Hoge Raad voorlopig vast aan zijn uitgangspunt van non-interventie.

Toetsing van lagere regelgeving

Het toetsingsverbod van artikel I20 Grondwet is een uitzondering op de regel dat de Nederlandse rechter bevoegd is om lagere regels te toetsen aan hogere. Dat brengt met zich mee dat toetsing van regelgeving, niet zijnde een wet in formele zin, aan de Grondwet niet op constitutionele bezwaren stuit. Ook toetsing van lagere regelgeving aan ongeschreven fundamentele rechtsbeginselen is door de Hoge Raad aanvaard, zij het dat de rechter terughoudend dient te toetsen. ${ }^{44}$

Toetsing van lagere regelgeving aan de Grondwet en aan ongeschreven rechtsbeginselen is dus mogelijk, maar er zijn gevallen waarin een dergelijke toetsing toch wordt verhinderd door artikel I20 Grondwet. Het gaat hier om die gevallen waarin toetsing van de lagere regelgeving in wezen neerkomt op toetsing van de wet zelf. Daarvan is sprake wanneer de lagere regeling louter de gebonden uitvoering van de formele wet vormt en de lagere regelgever derhalve niet de vrijheid toekwam een

44. HR I6 mei I986, NJ I987, 25I. Bevestigd in HR I4 april I989, NJ I989, 469. 
andere regeling naar eigen inzicht te treffen. ${ }^{45}$ De inhoud van de lagere regeling wordt dan als het ware reeds gedicteerd of in elk geval gelegitimeerd door de formele wet.

Vaak zal de lagere regelgever echter de vrijheid hebben om een met de Grondwet overeenstemmende regeling te treffen en in een dergelijk geval stuit toetsing van de lagere regelgeving niet op grondwettelijke bezwaren. De jurisprudentie laat diverse gevallen van 'toetsing over de wet heen' zien. Zo toetste de Hoge Raad in het arrest Vestigingsbesluit Grafische Bedrijven ${ }^{46}$ het besluit waaraan het arrest zijn naam dankt en dat was gebaseerd op de Vestingswet Bedrijven aan artikel 7 Grondwet inzake de drukpersvrijheid. En in een uitspraak van de Afdeling Geschillen van Bestuur uit 1992 werd toetsing van de Hinderwet aan artikel 7 Grondwet weliswaar onmogelijk geacht, maar toetsing van het daaruit voortvloeiende Hinderbesluit stuitte niet op constitutionele bezwaren. ${ }^{47}$ In datzelfde jaar achtte de Hoge Raad echter toetsing van de Regeling aanwijzing diersoorten en hun mestproductie aan artikel I04 Grondwet niet mogelijk. Volgens de Hoge Raad kwam het bezwaar van de eiser in cassatie in wezen hierop neer dat hij de in de Meststoffenwet vervatte delegatiebepalingen, waarop de genoemde Regeling was gebaseerd, in strijd met artikel ${ }_{04}$ Grondwet achtte. En toetsing van deze formeelwettelijke bepalingen aan de Grondwet stuit af op artikel I20 Grondwet. ${ }^{8}$

Ondanks het feit dat het de rechter toegestaan is lagere regelgeving te toetsen aan de Grondwet, is een dergelijke toetsing geen dagelijkse praktijk. ${ }^{49}$ Toch speelt de Grondwet in sommige gevallen nog steeds een belangrijke rol bij de toetsing van lagere regelgeving. Het beroemdste voorbeeld is wellicht de zogenaamde 'verspreidingsjurisprudentie' die gekoppeld is aan artikel 7 Grondwet, het artikel dat de drukpersvrijheid beschermt. Deze jurisprudentie is al meer dan honderd jaar oud..$^{0}$ Kort samengevat houdt zij in dat gemeentelijke en provinciale wetgevers de vrijheid om drukwerk te verspreiden aan banden mogen leggen, maar daarbij nooit zover mogen gaan dat een 'zelfstandig verspreidingsmiddel' in het algemeen wordt geboden of van een voorafgaand verlof van de overheid afhankelijk wordt gemaakt. Van ieder verspreidingsmiddel moet nog 'gebruik van enige betekenis' overblijven.

45. Vermeulen I995, p. 29. Zie tevens de noot van C.A.J.M. Kortmann onder ABRvS 24 juli 2002, AA 2003, p. 779-780. Uitgebreid over het vraagstuk zijn Van Houten I995, p. 460-462 en Van Houten I997, p. 80-85.

46. HR 23 mei I96I, NJ I96I, 427.

47. AGRvS 20 november I992, AB I993, 24I.

48. HR 23 december I992, BNB I993, I04.

49. Zie bijvoorbeeld Kamerstukken II 2006/07, 28 33 I, C, p. I3, waarin wordt opgemerkt: 'In 2004 werd in totaal 17 keer bij de hoogste rechterlijke instanties - Hoge Raad, CRvB, ABRvS, CBB - door de klagers een beroep gedaan op de Grondwet met als doel de voorliggende regeling of het voorliggende besluit aan te vechten. In de meeste gevallen (I2) werd een beroep op artikel I Grondwet gedaan. De artikelen 7, I0, I4, I6 en 22 Grondwet werden I keer ingeroepen. De rechters achtten in 6 gevallen het beroep op de grondrechtelijke bepaling gegrond. In 2005 werd 22 keer een beroep gedaan op de Grondwet. In I4 gevallen werd een beroep op artikel I Grondwet gedaan. De andere artikelen die werden ingeroepen waren artikel 7 ( 2 keer), artikel ro (3 keer), artikel I6, artikel I9 en artikel 89 Grondwet. Slechts I keer had het beroep succes.'

50. Het eerste arrest in een lange reeks werd gewezen in I892. Zie HR 7 november I892, W 6259. Tot de belangrijkste arresten van de verspreidingsjurisprudentie behoren HR 28 november I950, NJ I95I, I37, HR 27 februari I95I, NJ I95I, 357 en HR I7 maart I953, NJ I953, 389. Recentere uitspraken zijn HR I april I997, NJ I997, 457 en ABRvS I8 september 2002, LJN AE7789. 
Minstens zo belangrijk is dat de lagere overheden zich niet met de inhoud van het drukwerk mogen bemoeien. Dat mag alleen de formele wetgever. ${ }^{5 \text { I }}$

\section{Grondwetsconforme interpretatie}

Waar het de rechter niet toegestaan is de formele wet te toetsen aan de Grondwet, staat het hem wel vrij de wet waarvan de betekenis onduidelijk is in het licht van de Grondwet uit te leggen. ${ }^{52}$ Grondwetsconforme interpretatie verdraagt zich goed met het toetsingsverbod van artikel 120 Grondwet, nu het hier strikt genomen niet om toetsing, maar om uitleg van een wettelijke bepaling gaat. Het is niet gemakkelijk vast te stellen hoe vaak de Nederlandse rechter zich van deze interpretatiemethode bedient. Bij de interpretatie van een rechtsnorm kan heel goed op de achtergrond de Grondwet hebben meegespeeld zonder dat de rechter dat met zoveel woorden in zijn uitspraak vermeldt. Nu ook een grondwetsconforme interpretatie tamelijk verstrekkende gevolgen kan hebben, is het bovendien niet uitgesloten dat de rechter eerder zal uitwijken naar een verdragsbepaling en de formele wet verdragsconform uit zal leggen. ${ }^{53}$ Ook hier lijkt de Grondwet een betrekkelijk marginale rol te spelen.

De uitspraken waarin de rechter expliciet rept van grondwetsconforme interpretatie zijn op de vingers van een hand te tellen. Een voorbeeld is de uitspraak van de Afdeling bestuursrechtspraak van de Raad van State inzake De Nieuwe Omroep. ${ }^{54}$ Deze aspirant-omroeporganisatie had de staatssecretaris van OCW om een voorlopige erkenning gevraagd. De staatssecretaris had de aanvraag afgewezen omdat uit het overgelegde beleidsplan niet zou blijken dat de programma's van De Nieuwe Omroep zodanig afweken van die van de bestaande omroepen dat de verscheidenheid van de landelijke omroep werd vergroot en een vernieuwende bijdrage aan de verwezenlijking van de taakopdracht van de publieke omroep werd geleverd. De Afdeling kon de bepalingen van de Mediawet waarop de afwijzing was gebaseerd uiteraard niet toetsen aan de Grondwet, in casu artikel 7 lid 2.55 Dat nam volgens haar echter niet weg dat, wanneer de wet in formele zin bij toepassing in een concreet geval ruimte liet voor uiteenlopende besluiten, de wettelijke bepaling bij die toepassing grondwetsconform diende te worden uitgelegd. In casu was echter geen ruimte voor uiteenlopende besluiten, nu aan de staatssecretaris geen beleidsvrijheid toekwam en slechts een beperkte beoordelingsvrijheid. De uitspraak toont dan ook vooral aan dat de mogelijkheid van grondwetsconforme interpretatie bestaat.

5I. Uitgebreid over de verspreidingsjurisprudentie De Winter I993. Zie ook De Meij 2000, p. III-I26. Kistenkas 2003, p. I96 jubelt over deze jurisprudentie: 'De verspreidingsjurisprudentie never dies, it probably only fades away...'

52. Van Houten 1997, p. 46-5I.

53. Van der Pot 2006, p. 70I-702; Nollkaemper 2007, p. 465-468. Zie verder paragraaf 3.

54. ABRvS 24 juli 2002, AB 2003, 204; AA 2003, p. 779-780. Van Houten I997, p. 46-48 noemt onder meer nog een zeer oud arrest van de Hoge Raad uit 1858 waarin de Onteigeningswet in het licht van het toenmalige artikel 147 Grondwet werd uitgelegd.

55. De Afdeling stelt in dit verband dat gelet op artikel I20 Grondwet als uitgangspunt heeft te gelden dat bepalingen van een wet in formele zin niet in strijd zijn met de Grondwet. Dat standpunt lijkt ons wat te stellig. Een wet in formele zin kan wel degelijk in strijd zijn met de Grondwet. De rechter mag echter ingevolge artikel 120 geen rechtsgevolgen aan een eventuele ongrondwettigheid verbinden. 


\subsection{Het grondwettelijke beperkingssysteem}

Uit de voorgaande paragraaf is gebleken dat de rechter slechts een beperkte rol toekomt bij het waarborgen van de grondwettelijke grondrechten. Hij mag ingevolge artikel 120 Grondwet wetten in formele zin niet toetsen aan de Grondwet. Wel mag hij lagere regelgeving toetsen aan de Grondwet, mits toetsing van deze regelgeving niet in wezen neerkomt op toetsing van de wet zelf. In deze subparagraaf zal worden onderzocht onder welke voorwaarden de grondrechten uit Hoofdstuk I van de Grondwet mogen worden beperkt. Daarbij wordt ook enige aandacht besteed aan het vraagstuk van de zogenaamde horizontale werking van grondrechten.

Het uitgangspunt: de beperkingsclausule

Het grondwettelijke beperkingssysteem zoals dat vandaag de dag van kracht is

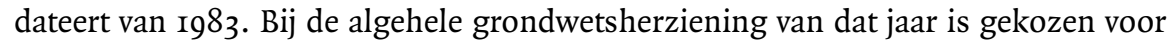
het uitgangspunt dat in principe iedere beperking van een grondwettelijk grondrecht moet zijn te herleiden tot de beperkingsclausule van dat grondrecht. ${ }^{56}$

Sommige grondrechten worden ongeclausuleerd toegekend. De twee bekendste voorbeelden zijn het discriminatieverbod van artikel I Grondwet ${ }^{57}$ en het censuurverbod dat in artikel 7 Grondwet vervat is, in het bijzonder in het eerste lid dat op de vrijheid van drukpers ziet.

De meeste grondrechtsbepalingen kennen echter wel een beperkingclausule. Deze bestaat dan in elk geval uit een competentievoorschrift, dat wil zeggen een voorschrift dat aangeeft welk orgaan bevoegd is het desbetreffende grondrecht te beperken. Zo bepaalt artikel 7 Grondwet dat de drukpersvrijheid geldt 'behoudens ieders verantwoordelijkheid volgens de wet' en kent artikel II Grondwet een recht op onaantastbaarheid van het lichaam toe 'behoudens bij of krachtens de wet te stellen beperkingen'. In alle beperkingsclausules valt de centrale plaats van de formele wet op. Het is steeds de wetgever - dus regering en Staten-Generaal gezamenlijk - aan wie de bevoegdheid wordt geattribueerd het grondrecht te beperken. Soms mag de wetgever delegeren aan andere organen (zoals de regering, individuele ministers en decentrale wetgevers), ${ }^{58}$ maar in alle gevallen dient de beperking van het grondrecht herleidbaar te zijn tot een bepaling in een formele wet. De positie van de formele wetgever is dus wederom sterk.

De centrale plaats van de wetgever wordt nog verder vergroot door de eis dat elke beperking door een ander orgaan dan de formele wetgever moeten kunnen worden herleid tot een specifieke formeelwettelijke bepaling. Gemeenteraden kunnen bijvoorbeeld niet op basis van hun meer algemene autonome verordenende bevoegdheid (artikel I47 juncto I49 Gemeentewet) grondrechten als het recht op respect voor de

56. Verhey 2003, p. 219.

57. Discriminatie is dus te allen tijde verboden. Het komt er derhalve op aan welke handelingen als 'discriminatie' worden aangemerkt. Dat is een vraag naar de reikwijdte van het grondrecht.

58. De Grondwet kent terzake een eigen delegatieterminologie. Spreekt zij van beperkingen 'bij of krachtens de wet' of gebruikt zij enige vorm van het werkwoord 'regelen' of het zelfstandig naamwoord 'regels' of 'regeling' dan is delegatie geoorloofd. In andere gevallen - bijvoorbeeld 'behoudens ieders verantwoordelijkheid volgens de wet' - is delegatie verboden. Zie Vermeulen I995, p. 5; De Meij 2000, p. 50. 
persoonlijke levenssfeer beperken. Artikel to Grondwet maakt weliswaar delegatie door de formele wetgever mogelijk en de Gemeentewet is weliswaar een wet in formele zin, maar de algemene regelingsbevoegdheden van de artikelen I47 en I49 Gemeentewet missen het voor een beperking van grondwettelijke grondrechten vereiste specifieke karakter. ${ }^{59}$ Met andere woorden: de wettelijke bepaling tot welke de beperking moet kunnen worden herleid moet specifiek gemaakt zijn met het oog op het beperken van grondrechten. ${ }^{60}$

Bij het strikte vereiste van een specifieke wettelijke grondslag zijn wel enige kanttekeningen mogelijk. In sommige gevallen bleek de rechter namelijk coulanter en accepteerde hij ook beperkingen gebaseerd op de hiervoor genoemde algemene regelingsbevoegdheden van de Gemeentewet, zoals in het geval van een plaatselijke verordening die het aanlokken tot prostitutie verbood. ${ }^{61}$ Ook een drankverbod voor een sergeant van de Koninklijke Marine dat enkel kon worden teruggevoerd op artikel 44 lid I Grondwet werd door de rechter geaccepteerd. ${ }^{62} \mathrm{Nu}$ ging het in beide zaken bepaald niet om ingrijpende overheidsinmengingen in grondrechten (in casu de persoonlijke levenssfeer). Sterker nog, men kan zich afvragen of er überhaupt grondrechten in het geding waren. Hoe dit ook zij, wellicht mogen beperkingen van beperkte omvang eerder gebaseerd worden op een globaal geformuleerde bevoegdheid of zelfs op een globale taakomschrijving, zoals artikel 2 Politiewet. ${ }^{63}$

Een tweede kanttekening is dat het strakke beperkingssysteem niet, of niet onverkort, geldt in horizontale verhoudingen, dat wil zeggen verhoudingen waar de overheid niet bij betrokken is. Deze horizontale werking van grondrechten komt hieronder nog aan de orde. Hier kan alvast gesteld worden dat de rechter bij verhou-

59. Kamerstukken II I975/76, I3 872, nr. 3, p. 23; Rb. Roermond 3 januari I995, AB I995, I68; ABRvS 28 augustus I995, AB I996, 204. Zie ook HR 2 juli I990, NJ I990, 75I over het afnemen van wangslijm ten behoeve van een strafrechtelijk onderzoek. Volgens de Hoge Raad ontbrak voor deze vergaande maatregel de door artikel II Grondwet vereiste specifieke wettelijke grondslag. De algemene bepalingen in het Wetboek van Strafvordering over onderzoek aan het lichaam konden niet als zodanig beschouwd worden.

6o. De regering stelde bij de Grondwetsherziening van 1983 : 'Wanneer de wetgever in enig geval beperkingsbevoegdheid aan een ander orgaan wil overdragen, dient dit bewust en na afweging van belangen te geschieden en moet de wet daarvan blijk geven. Welke wet dat is doet niet ter zake. Delegatiebepalingen kunnen in beginsel in elke wet voorkomen, mits uit de wet met voldoende duidelijkheid kan worden afgeleid, dat de wetgever bewust een beperkingsbevoegdheid heeft willen toekennen en ten aanzien van welk grondrecht hij dat heeft gewild.' Kamerstukken II 1976/77, I3 872 , nr. 7, p. I4; Vermeulen I995, p. 4-5.

6I. Hof Den Bosch ig november 2003, NJ 2004, 64. In deze uitspraak werd overwogen dat 'artikel io, eerste lid, van de Grondwet het mogelijk (maakt) dat beperkingen van de persoonlijke levenssfeer worden gesteld bij of krachtens de wet. Derhalve heeft de gemeenteraad, die krachtens de artikelen I 47 en I 49 van de Gemeentewet bevoegd is verordeningen te maken die hij in het belang van de gemeente nodig acht (...) de bevoegdheid om dergelijke beperkingen te stellen.'

62. CRvB 3 mei 2002, AB 2002, 346. Artikel 44 lid I Grondwet bepaalt niet meer dan dat bij koninklijk besluit ministeries worden ingesteld en dat deze onder leiding van een minister staan. De CRvB leidt daaruit een bevoegdheid af tot het geven van voorschriften betreffende de interne organisatie en de werkwijze van de ambtelijke dienst.

63. Vgl. HR i9 december I995, NJ I996, 249, waarin de Hoge Raad overwoog dat 'ook indien door zulke verrichtingen een beperkte inbreuk op de persoonlijke levenssfeer zou worden gemaakt, de globale taakomschrijving van art. 2 Politiewet 1993 daarvoor een toereikende wettelijke grondslag biedt'. 
dingen tussen particulieren ook beperkingen op grond van het globaal geformuleerde artikel 6:I62 BW inzake de onrechtmatige daad toelaatbaar acht. ${ }^{64}$

Tegenover de vereisten ten aanzien van de bevoegdheid staat dat de Grondwet nauwelijks materiële criteria voor grondrechtenbeperkingen kent. Het recht van eenieder zijn godsdienst of levensovertuiging vrij te belijden (artikel 6 Grondwet) geldt bijvoorbeeld 'behoudens ieders verantwoordelijkheid volgens de wet', maar de Grondwet maakt volstrekt niet duidelijk welke belangen in welke omstandigheden een beperking kunnen rechtvaardigen. Voor de drukpersvrijheid ex artikel 7 lid I Grondwet geldt hetzelfde.

In sommige gevallen noemt een grondwetsartikel doelcriteria. Zo kan de verenigingsvrijheid alleen worden beperkt 'in het belang van de openbare orde' (artikel 8 Grondwet) en kan de wet de bevoegdheid om het recht van vergadering en betoging in te perken slechts delegeren 'ter bescherming van de gezondheid, in het belang van het verkeer en ter bestrijding of voorkoming van wanordelijkheden' (artikel 9 lid 2 Grondwet). Door de bank genomen is het aantal (uitdrukkelijke) materiële beperkingscriteria echter zeer beperkt. Heel soms geeft de Grondwet procedurevoorschriften. Zo bepaalt artikel I2 Grondwet dat bij het binnentreden van woningen de overheid in beginsel gehouden is zich te legitimeren en mededeling te doen van het doel van het binnentreden.

Nergens in de Grondwet is een proportionaliteitstoets vastgelegd. Niettemin heeft de regering zich in 2000 op het standpunt gesteld dat een dergelijke toets in de diverse grondwettelijke bepalingen moet worden ingelezen. ${ }^{65}$ De regering stelde zich in een reactie op het rapport van de eerder genoemde Commissie-Franken op het standpunt dat beperkingen van grondrechten moeten voldoen aan de eisen van proportionaliteit en subsidiariteit. Bovendien zou gelden dat een grondrecht door een beperkende maatregel niet illusoir gemaakt mag worden. Uit het karakter van de grondrechten zou verder reeds voortvloeien dat beperkingen hiervan noodzakelijk moeten zijn in een democratische samenleving. 'Ook nu reeds zal de wetgever moeten motiveren waarom een beperking op een grondrecht nodig is in onze samenleving', aldus de regering. Zij zag daarom geen reden om een expliciete proportionaliteitstoets in de Grondwet vast te leggen, iets waarvoor in de literatuur wel gepleit was. ${ }^{66}$

Deze overwegingen van de regering hebben tot nogal wat kritiek in de literatuur geleid, met name van Kummeling en Verhey. ${ }^{67}$ Inderdaad gaat het nogal ver om in grondwetsbepalingen allerhande zaken te lezen die er niet expressis verbis in staan. Het standpunt van de regering lijkt voorts weinig steun te vinden in de parlementaire geschiedenis van de grondwetsherziening van $1983 .{ }^{68}$ Die geeft eerder steun aan de stelling dat de grondwetgever zich over concrete beperkingen en belangenafwegin-

64. Zie bijvoorbeeld HR 5 juni I987, NJ I988, 702.

65. Kamerstukken II 2000/oI, 27 46o, nr. I, p. 6.

66. Zie bijvoorbeeld het rapport van de Studiecommissie VMC, Mediaforum I999-II/I2, Bijlage p. I-VIII.

67. Kummeling 200I, p. 245-250; Verhey 2003, p. 229.

68. Voor zover wij kunnen overzien, kan alleen de opmerking over het verbod om grondrechten illusoir te maken rechtstreeks op de parlementaire geschiedenis worden teruggevoerd. Zie Kamerstukken II I976/77, I3 872, nr. 7, p. 33 waarover Gerbranda \& Kroes I993, p. 35. 
gen niet heeft willen uitlaten, met als gevolg een sterk formeel gekleurde beperkingsclausule met een nagenoeg ongelimiteerde beperkingsbevoegdheid voor de wetgever. $^{69}$

Het is ons inziens hooguit te verdedigen dat de bepalingen van de Grondwet, waarin doelcriteria zijn opgenomen, een impliciet vereiste van proportionaliteit kennen. Het zou immers merkwaardig zijn indien bijvoorbeeld een vlotte afwikkeling van het verkeer in de ogen van de grondwetgever steeds een hoger goed zou zijn dan de uitoefening van het grondrecht van vrijheid van betoging. ${ }^{70}$ Dat impliceert op zijn minst dat er een afweging plaats dient te vinden tussen het belang van het verkeer en het belang van de vrijheid van betoging. Niettemin verdient, indien de grondwetgever daadwerkelijk een proportionaliteitstoets heeft gewild, het expliciet vastleggen van een dergelijk vereiste de voorkeur.

De wetgever lijkt zich tijdens de wetgevingsprocedure weinig te bekommeren om een systematische beoordeling van beperkingen van grondwettelijke grondrechten aan de hand van het proportionaliteitsbeginsel. De 'toetsing' door de wetgever aan de Grondwet ligt sowieso wel onder vuur. Gerbranda en Kroes, die de toetsing door de wetgever vanaf 1983 onderzochten, constateren dat de wetgever vaak formalistisch te werk gaat en zich weinig rekenschap geeft van de aan de grondrechten ten grondslag liggende waarden. Van consistente en goed gemotiveerde belangenafwegingen is lang niet altijd sprake en in een aantal gevallen gaat de wetgever te gemakkelijk over tot delegatie, zonder de grondrechtelijke aspecten daarbij te betrekken. ${ }^{7 \mathrm{I}}$ Ook na het onderzoek van Gerbranda en Kroes zijn de nodige kritische beschouwingen over 'toetsing' door de wetgever aan de Grondwet verschenen. ${ }^{72} \mathrm{Nu}$ is er tegenwoordig in de wetgevingsprocedure vaak wel aandacht voor het EVRM en de daarin opgenomen voorwaarden voor beperking van grondrechten. ${ }^{73}$ In dat kader kan ook het vereiste van proportionaliteit aan bod komen. Overigens spelen in parlementaire debatten vaak argumenten van politieke wenselijkheid een belangrijke rol, zeker na de gebeurtenissen van II september 200I. Daardoor kan de betekenis van de grondrechten naar de achtergrond verschuiven.

Of het standpunt van de regering ten aanzien van een inherent vereiste van proportionaliteit volgens geldend recht juist is of niet, het kan in de toekomst zeker nog een rol gaan spelen wanneer het initiatiefvoorstel-Halsema inzake constitutionele toetsing wordt aangenomen. De initiatiefneemster heeft in de toelichtende stukken expliciet aangegeven dat het de bedoeling is dat de rechter beperkingen van grondwettelijke grondrechten gaat toetsing op proportionaliteit en subsidiariteit. ${ }^{74}$ Het lijkt voor de hand te liggen dat ook de wetgever dan in de parlementaire stukken en

69. Gerbranda \& Kroes I993, p. 92; Verhey 2003, p. 229.

70. Zie voor de opvatting van de regering Kamerstukken II I976/77, I3 872, nr. 7, p. 34 .

7I. Gerbranda \& Kroes I993, p. 92-I02.

72. Kummeling 200I, p. 248-249; Verhey 2003, p. 222; Albers \& Schlössels 2006, p. 2526.

73. Zie voor dit onderwerp ook de nog in boekvorm te verschijnen preadviezen voor de Staatsrechtconferentie 2007 over het thema 'wetgever en grondrechten'.

74. Kamerstukken I 2006/07, 28 33I, C, p. I3; Kamerstukken I 2007/08, 28 33I, E, p. I4. Hierover ook Hins 2005 , p. 66. 
debatten aangeeft waarom de beperking proportioneel is en voldoet aan de vereisten van subsidiariteit.

De redelijke uitleg als meer inhoudelijke toets?

De verplichte betrokkenheid van de formele wetgever bij de beperking van grondrechten is de sterkste troef bij de Nederlandse grondrechtenbescherming. De strakke, formalistische benadering van de Grondwet kan echter tot problemen leiden in die situaties waarin beperking van een grondrecht alleszins redelijk is, maar een specifieke formeelwettelijke grondslag ontbreekt. De eis van een dergelijke grondslag legt verder een (te) zware druk op de reeds overbelaste wetgever, die bovendien toch moeilijk op voorhand alle benodigde beperkingen van grondrechten kan aangeven. 75

Een mogelijke uitweg zou kunnen zijn het maken van een onderscheid tussen zogenaamde algemene en bijzondere beperkingen van grondrechten. Waar bijzondere beperkingen specifiek met het oog op beperking van een grondrecht zijn vastgesteld, geldt hetzelfde niet voor algemene beperkingen. Daarbij gaat het om algemene rechtsregels die geheel buiten de sfeer van het grondrecht liggen, maar wel als neveneffect hebben dat het grondrecht beperkt wordt. ${ }^{76}$ Men denke aan voorschriften die het aantal aanwezigen in een vergaderzaal beperken in het belang van de brandveiligheid, het vereiste van een bouwvergunning voor een kerk of moskee en het vereiste van een vergunning op grond van de Wet milieubeheer voor een drukkerij. Op zichzelf behoren dergelijke voorschriften tot de algemene spelregels van de maatschappij, maar niettemin kan betoogd worden dat zij de vrijheid van vergadering, godsdienst en drukpers beperken.

Volgens de zogenaamde 'leer van de algemene beperkingen' hoeven alleen bijzondere beperkingen tot de grondwettelijke beperkingsclausule herleidbaar te zijn. Voor algemene beperkingen zou dat niet gelden. ${ }^{77}$ Deze leer is echter door de grondwetgever in 1983 uitdrukkelijk verworpen: iedere beperking, algemeen of bijzonder, moet kunnen worden herleid tot de beperkingsclausule bij het grondrecht. ${ }^{7}$ De grondwetgever realiseerde zich tegelijkertijd dat het in alle gevallen vasthouden aan dit strakke uitgangspunt ongewenste gevolgen zou kunnen hebben. Daarom liet hij een aantal achterdeurtjes openstaan om te ontsnappen aan de dwang van de nieuwe grondwettelijke beperkingssystematiek.

De belangrijkste daarvan was de 'redelijke uitleg' van grondrechten: de regering betoogde dat niet alleen een grondrecht op redelijke wijze moest worden uitgelegd, maar dat ook aan de redelijkheid grenzen konden worden ontleend waarbuiten een grondrecht geen toepassing meer behoort te vinden. ${ }^{79}$ Daarbij werd expliciet het voorbeeld van een Hinderwetvergunning voor een drukkerij gegeven. Volgens de leer van de algemene beperkingen zou dit een algemene beperking zijn, en zou deze dus niet aan de clausulering hoeven te voldoen. De redelijke uitleg van grondrechten

75. Vgl. Vermeulen I995, p. I9.

76. Verhey 2003 , p. 217.

77. Vermeulen I995, p. I-2; De Meij 2000, p. 52.

78. Van der Pot 2006, p. 282-283.

79. Kamerstukken II I975/96, I3 872, nr. 3, p. 2 I. 
brengt echter - in de visie van de regering - mee dat überhaupt geen sprake is van een beperking. De maatregel ligt buiten de werkingssfeer van het grondrecht en is daarom zonder meer toegestaan. ${ }^{80}$ Zoals te verwachten was, heeft deze benadering kritiek opgeroepen: de leer van de algemene beperkingen zou via de voordeur naar buiten zijn gewerkt, maar vervolgens als de leer van de redelijke uitleg en redelijke toepassing weer via de achterdeur zijn binnengelaten.

Op zichzelf zal de redelijke uitleg van een grondrecht inderdaad niet zelden hetzelfde resultaat hebben als de toepassing van de leer van de algemene beperkingen. ${ }^{8 \mathrm{I}}$ Vermeulen heeft er echter terecht op gewezen dat de redelijke uitleg onder omstandigheden juist méér bescherming kan bieden dan de toepassing van de leer van de algemene beperkingen. ${ }^{82}$ Dat blijkt uit naar zijn mening uit een aantal uitspraken van de (voormalige) Afdeling Rechtspraak van de Raad van State waarin een dubbele redelijkheidstoets plaatsvindt. De rechter verricht in het kader van de redelijke uitleg eerst een abstracte toetsing op regelniveau. Daaruit blijkt dan of het grondrecht in het geding is of niet. Is dat niet het geval, dan kijkt de rechter vervolgens niettemin of de specifieke toepassing van de bestreden maatregel in het voorliggende geval redelijkerwijs toch niet neerkomt op een beperking van het grondrecht. Bij deze concrete toetsing spelen overwegingen van proportionaliteit en een beoordeling van de resterende feitelijke mogelijkheden tot gebruik een belangrijke rol. ${ }^{83}$

Een goed voorbeeld van een dubbele redelijkheidstoets is te vinden in de uitspraak van de Afdeling Rechtspraak van I6 juni 1993. ${ }^{84}$ Centraal in deze uitspraak stond de Geluidhinderverordening van de gemeente Amersfoort die - kort gezegd - verbood om in de open lucht een geluidsapparaat in werking te hebben op zodanige wijze dat daardoor geluidshinder wordt veroorzaakt. Burgemeester en wethouders konden van dit voorschrift ontheffing verlenen. De Evangelisatiegemeente 'De Deur' had om een dergelijke ontheffing gevraagd, nu zij voor haar openbare evangelische manifestaties gebruik wenste te maken van geluidsversterkende apparatuur. De ontheffing werd geweigerd. De Afdeling oordeelde in beroep dat het verbod in combinatie met de ontheffingsmogelijkheid op zichzelf niet in strijd was met de in artikel 6 Grondwet verankerde godsdienstvrijheid. 'Een redelijke uitleg van dit grondwetsartikel brengt met zich mee dat degenen die dit recht uitoefenen daarbij onderworpen zijn aan de bepalingen die in algemene zin zijn gesteld ter voorkoming of beperking van geluidhinder.' Daarmee is de kous nog niet af, want de Afdeling overweegt vervol-

8o. Zie ook AGRvS 20 november I992, AB I993, 24I, waarin de Afdeling overweegt dat het Hinderbesluit noch tot doel, noch tot effect heeft het oprichten van drukkerijen te beletten. Van een beperking van de drukpersvrijheid ex artikel 7 Grondwet is dan ook geen sprake. Deze uitspraak heeft zowel trekken van de (verworpen) leer van de algemene beperkingen als van de redelijke uitleg van grondrechten. Vreemd genoeg is volgens de Afdeling wél sprake van een beperking van artikel Io EVRM, zij het dat deze op grond van het tweede lid van artikel ro geoorloofd is. Zie tevens de conclusie van de A-G Meijers bij HR ir februari I986, NJ I986, 673.

8I. Vgl. Vermeulen I995, p. 9; Verhey 2003, p. 220-22I; Van der Pot 2006, p. 284. Gerbranda \& Kroes I993, p. Io4 stellen de redelijke uitleg vaker voorkomt dan de grondwetgever in I $_{9} 83$ voor ogen stond, maar dat deze leer niet zo ruim geïnterpreteerd wordt dat algemene beperkingen zoals verworpen door de grondwetgever erkend worden.

82. Vermeulen 1995 , p. Io.

83. Vermeulen I995, p. I2-I6. Daarover ook Verhey 2003, p. 222-224.

84. ARRvS I6 juni i993, AB I994, 424. 
gens dat verweerders er wel voor moeten waken dat zij niet een zodanig restrictief ontheffingsbeleid gaan voeren dat dit gaat functioneren als een grondrechtenbeperking. Het aan banden leggen van het gebruik van een geluidversterkend apparaat voor godsdienstuitoefening mag niet verder gaan dan strikt noodzakelijk is ter voorkoming of beperking van geluidshinder.

Op deze wijze wordt met de redelijke uitleg niet zonder meer de door de grondwetgever beoogde uitzondering op het grondwettelijke beperkingssysteem gecreëerd. De overheidsmaatregel wordt immers niet (automatisch) gesauveerd door de redelijke uitleg, maar onder omstandigheden nu juist onrechtmatig geoordeeld. Het is overigens wel de vraag of hier van bestendige jurisprudentie sprake is. ${ }^{85}$

\section{Horizontale werking en botsing}

Tot dusverre is voornamelijk gesproken over de werking van de grondwettelijke grondrechten in de relatie tussen overheid en burger. De grondwetgever heeft in I983 echter uitdrukkelijk erkend dat grondrechten ook een zekere - horizontale werking kunnen hebben in relaties waarbij de overheid niet betrokken is. De regering onderscheidde verschillende maten van horizontale werking. De sterkste mate is die waarbij de rechter de grondrechtsbepaling inclusief de beperkingsclausule toepast in een relatie tussen burgers onderling. De zwakste mate is die waarbij de wetgever grondrechtelijke belangen verdisconteert in een regeling die (ook) van toepassing is in relaties tussen burgers. Tussen deze twee polen bevinden zich de andere wijzen van horizontale werking die er steeds op neer komen dat de rechter het grondrecht(elijk belang) laat meewegen in relaties tussen burgers onderling, bij de invulling van een open rechtsbegrip, als zelfstandig rechtsbelang of als zwaarwegend rechtsbeginsel. ${ }^{86}$

De regering liet echter in het midden welke grondrechten in welke gevallen welke mate van horizontale werking toekomt. Ook daarom behoort het leerstuk van de horizontale werking niet tot de meest heldere leerstukken in het Nederlandse recht. Daar kan nog aan toegevoegd worden dat men zich kan afvragen of werking via wetgeving wel als horizontale werking van het grondrecht is te beschouwen. ${ }^{87} \mathrm{De}$ vraag of er bij een beperking van een grondrecht, opgelegd door de rechter in een zaak tussen particulieren, sprake is van horizontale of verticale werking wordt evenmin eenduidig beantwoord. In geval de nadruk op de horizontale relatie tussen de procespartijen ligt, is het antwoord anders dan wanneer het feit vooropstaat dat de

85. In ABRvS 5 januari 1996, AB I996, I79, waarin het wederom ging om evangelisatiegemeente De Deur, vond geen (uitdrukkelijke) redelijke uitleg van grondrechten plaats. In deze uitspraak oordeelde de Afdeling dat appellant een beroep toekwam op het met het recht op belijden en betogen verbonden (connexe) recht op geluidsversterking, dat niet rechtstreeks werd beschermd door artikel 6 en 9 Grondwet, maar wel door artikel 7 lid 3 Grondwet. Beperking van dit recht was aanvaardbaar indien aan een aantal voorwaarden voldaan was: zij mocht geen betrekking hebben op de inhoud van de uitingen, diende noodzakelijk en proportioneel te zijn en er diende gebruik van enige betekenis over te blijven.

86. Kamerstukken II I975/76, I3 872, nr. 3, p. I5-I6; Van der Pot 2006, p. 288-289.

87. Zie o.a. De Meij 200o, p. 83. Deze merkt op dat het grondrecht in deze minst vergaande wijze van horizontale werking materieel een belangrijke rol zal blijven spelen, ook al is het formeel de wettelijke regeling die zich tot de burger richt, en niet de Grondwet. 
rechter een overheidsorgaan is. ${ }^{88}$ Een argument voor de laatste benadering zou kunnen zijn dat een dergelijke beperking in het EVRM-systeem in beginsel beoordeeld moet worden op grond van de onthoudingsplicht. Stelt men zich op het standpunt dat er in een dergelijk geval inderdaad geen sprake is van horizontale werking, dan zal het overigens moeilijk worden om in de jurisprudentie voorbeelden te vinden van de hierboven geschetste sterkste vorm van horizontale werking.

Zelfs in gevallen waarin het erop lijkt dat van de sterkste vorm van horizontale werking sprake is en de beperkingsclausule van het grondrecht dus strikt zou moeten worden toegepast, lijkt de rechtspraak coulanter te zijn dan wanneer het verticale verhoudingen zou betreffen. In het Goeree-arrest ${ }^{89}$ accepteerde de Hoge Raad bijvoorbeeld dat een beperking van de godsdienstvrijheid (artikel 6 Grondwet) werd gebaseerd op artikel I40I BW (thans artikel 6:I62 BW). Het hof had volgens de Hoge Raad 'terecht geoordeeld dat de in art. 6 Grondwet aan die vrijheid gestelde grens van "ieders verantwoordelijkheid volgens de wet" betekent dat ook art. I4OI BW beperkingen kan stellen aan de wijze waarop van die vrijheid gebruik wordt gemaakt'. Men kan echter onmogelijk volhouden dat het genoemde algemene onrechtmatigedaadsartikel de specifieke formeelwettelijke bepaling is die volgens het grondwettelijke beperkingssysteem vereist zou zijn.

Wat er ook zij van genoemde onduidelijkheden, er kan in het privaatrecht van een toenemende betekenis van grondrechtelijke belangen worden gesproken..$^{\circ}$ Daarbij is het echter vaak moeilijk aan te geven of de Grondwet hier (ook) een inspiratiebron vormt of dat de rechter zich vooral laat inspireren door het EVRM. ${ }^{9 \mathrm{I}}$ Het is wat dat betreft makkelijker om wetgeving aan te wijzen die geldt tussen particulieren en die uitdrukkelijk (mede) geïnspireerd is door de grondwettelijke grondrechtsbepalingen. Dat is uiteraard in het bijzonder het geval wanneer de Grondwet de wetgever opdraagt om het grondrecht nader vorm te geven, ook tussen burgers onderling. Een goed voorbeeld vormt de Wet bescherming persoonsgegevens waarmee de wetgever niet alleen een EG-richtlijn implementeert maar ook voldoet aan de opdrachten in artikel ro lid 2 en 3 Grondwet.

Het komt met enige regelmaat voor dat particulieren die voor de rechter tegenover elkaar staan beide een beroep kunnen doen op een grondrecht. Bij een dergelijke botsing van grondrechten of, beter gezegd, van grondrechtelijke belangen zal de rechter veelal een afweging dienen te maken tussen de onderscheiden belangen. $\mathrm{Nu}$ tussen de in de Grondwet vastgelegde grondrechten onderling geen hiërarchie bestaat, zullen de omstandigheden van het geval in belangrijke mate bepalen welk grondrechtelijk belang in het concrete geval het zwaarste dient te wegen. ${ }^{92}$ Zo heeft de Hoge Raad in het verleden een reeks van factoren aangegeven die de rechter in zijn afwegingen dient te betrekken wanneer hij met de vraag geconfronteerd wordt

88. Van der Pot 2006, p. 290 verdedigt het standpunt dat waar de rechter in feite bestuurlijke maatregelen treft, het vraagstuk van horizontale werking niet aan de orde is. Daarbij gaat het dan om zaken als een straatverbod of een publicatieverbod.

89. HR 5 juni 1987, NJ I988, 702.

90. Van der Pot 2006, p. 289.

9I. Zie onder meer Mak 2007.

92. Vgl. HR 4 maart I988, NJ I989, 36r. 
of een perspublicatie die de privacy raakt onrechtmatig is of niet. ${ }^{93}$ Juist in dit soort gevallen zal er dus ook een materiële afweging tussen het belang van de persvrijheid en het belang van de privacy moeten plaatsvinden, waarin het beginsel van proportionaliteit op zijn minst een zekere rol speelt.

Overigens heeft ook de wetgever regels gesteld die zien op de 'botsing' van grondrechten. Een goed voorbeeld vormt de Algemene wet gelijke behandeling. Daarin wordt het gelijkheidsbeginsel van artikel I Grondwet uitgewerkt op het gebied van de arbeid, het vrije beroep en het leveren van goederen en diensten. ${ }^{94}$ Een aantal bepalingen van de wet is te beschouwen als het resultaat van een afweging tussen het belang van het beginsel van gelijke behandeling enerzijds en andere grondrechten als de vrijheid van godsdienst, de vrijheid van vereniging, de vrijheid van onderwijs en het recht op bescherming van de persoonlijke levenssfeer anderzijds. De artikelen 5 tot en met 7 van de wet verklaren doorgaans eerst dat het maken van (direct en indirect) onderscheid op het betreffende gebied verboden is, om vervolgens onder bepaalde voorwaarden uitzonderingen toe te staan aan bijvoorbeeld religieuze en politieke instellingen of instellingen van bijzonder onderwijs.

Gezien het toetsingsverbod van artikel I20 Grondwet zal de rechter zich in beginsel moeten laten leiden door de afweging die de wetgever ten aanzien van de grondwettelijke grondrechten heeft gemaakt. Dat betekent echter niet dat hij - of de op grond van de Algemene wet gelijke behandeling ingestelde Commissie gelijke behandeling - geen enkele afweging meer kan maken. Artikel 7 lid 2 Awgb bepaalt bijvoorbeeld dat het verbod om onderscheid te maken bij het leveren van goederen en diensten de vrijheid van een bijzondere onderwijsinstelling onverlet laat 'om bij de toelating en ten aanzien van de deelname aan het onderwijs eisen te stellen, die gelet op het doel van de instelling nodig zijn voor de verwezenlijking van haar grondslag, waarbij deze eisen niet mogen leiden tot onderscheid op grond van het enkele feit van politieke gezindheid, ras, geslacht, nationaliteit, hetero- of homoseksuele gerichtheid of burgerlijke staat'. In een zaak van een katholieke school die het dragen van hoofddoeken verbood kon de CGB toetsen of het verbod gelet op het doel van de school noodzakelijk was voor de verwezenlijking van de grondslag van de school en of het was gegrond op een consistent en op het doel van de school berustend beleid. ${ }^{95}$ Aldus kan toch een zekere afweging in concreto worden gemaakt.

\section{Bescherming op grond van het EVRM}

Deze paragraaf zet uiteen welke bescherming de Nederlandse rechter kan bieden op grond van het EVRM. Eerst komen enkele aspecten van de toepassing en de uitleg van de verdragsbepalingen door het EHRM aan bod. Het is uiteraard onmogelijk om in dit bestek een volledig overzicht te geven van de complexe en zich ontwikkelende jurisprudentie van het Hof. ${ }^{96}$ Wij beperken ons tot een aantal elementen: de auto-

93. HR 24 juni $\mathrm{I}_{98} 8$, NJ I984, 80I; HR 8 maart I985, NJ I986, 437.

94. In de considerans van de wet wordt ook naar artikel I Grondwet verwezen.

95. CGB 5 augustus 2003 (oordeel 2003-II2).

96. Zie onder andere Vande Lanotte \& Haeck 2004 en 2005 (meerdere delen); Van Dijk e.a. (ed.) 2006. 
nome, dynamische en teleologische uitleg van de verdragsbepalingen, de ontwikkeling van de positieve verplichtingen, en de appreciatiemarge die het Hof aan de nationale autoriteiten laat. Ook is er ruimte voor een korte uiteenzetting van de wijze waarop het EHRM de beperkingsvoorwaarden van artikel $8 \mathrm{t} / \mathrm{m}$ II EVRM heeft uitgewerkt. Deze elementen zijn gekozen, omdat daaruit bij uitstek het contrast met de grondwettelijke bescherming van grondrechten blijkt of omdat zij van belang zijn voor het antwoord op de vraag welke bescherming de Nederlandse rechter op basis van de verdragsrechten kan bieden.

Daarna komt de doorwerking van de jurisprudentie van het EHRM in de Nederlandse rechtsorde voor het voetlicht. Vervolgens worden twee kwesties in het bijzonder uitgelicht, namelijk de vraag of de Nederlandse rechter op grond van het EVRM meer bescherming mag bieden dan het EHRM en de vraag wanneer de rechter bij het bieden van rechtsbescherming stuit op de grenzen van zijn rechtsvormende taak.

\section{I Interpretatie door het EHRM}

Het EVRM en de bijbehorende protocollen leggen een reeks van - klassieke - grondrechten vast. Bij het verdrag is het EHRM in het leven geroepen. Staten kunnen daarbij zaken aanhangig maken (artikel 33 EVRM) en individuen kunnen na uitputting van de nationale rechtsmiddelen verzoekschriften indienen indien zij menen dat hun verdragsrechten zijn geschonden (artikel 34 en 35 EVRM). Bij de beoordeling van statenklachten en individuele verzoekschriften geeft het EHRM tegelijkertijd een bindende interpretatie van de verdragsbepalingen:

'The Court's judgements in fact serve not only to decide those cases brought before the Court but, more generally, to elucidate, safeguard and develop the rules instituted by the Convention, thereby contributing to the observance by the States of the engagements undertaken by them as Contracting Parties (art. I9)., 97

Door de grote hoeveelheid individuele verzoekschriften krijgt het Hof met andere woorden alle gelegenheid tot uitleg van de verdragsbepalingen en tot rechtsontwikkeling. ${ }^{98}$ De uitleg betreft zowel de reikwijdte van de verdragsbepalingen als de toepassing. ${ }^{99}$ Daarbij valt op te merken dat het Hof veelal eerst een aantal algemene overwegingen aan de betekenis van een bepaald grondrecht wijdt, maar de jurisprudentie voor een deel toch sterk casuïstisch van aard is. Deze benadering sluit overigens niet uit dat bepaalde begrippen worden uitgelegd op een wijze, die 'voor herhaalde toepassing vatbaar is'. In sommige gevallen blijkt een arrest er ook nadrukkelijk op gericht dat in alle lidstaten een uniforme toepassing aan een verdragsbepaling wordt gegeven. ${ }^{\text {I0o }}$

97. EHRM I8 januari I978, Ireland v. United Kingdom, Vol. A 25.

98. Lawson 2000, p. I5-16.

99. Zie voor het onderscheid tussen vaststelling reikwijdte en toepassing, Gerards 2006, p. 94 e.v.

I00. EHRM 8 december I999, Pellegrin v. France, zie daarover Gerards 2006, p. 99 e.v. Zie voor een nadere uitwerking van Pellegrin, EHRM ig april 2007, Vilho Eskelinen a.o. v. Finland. 
Autonome, dynamische en teleologische uitleg ${ }^{101}$

Het EHRM geeft een autonome uitleg van de verdragsbepalingen. De reikwijdte en betekenis van een verdragsbepaling is in het algemeen dus niet afhankelijk van het relevante nationale recht van een staat. ${ }^{\text {I02 }}$ Zo bepaalt het EHRM zelfstandig welke geschillen onder de in artikel 6 EVRM genoemde geschillen over de vaststelling van burgerlijke rechten vallen. ${ }^{\text {I03 }}$ Een staat kan niet simpelweg tegenwerpen dat het geschil naar nationaal recht een administratiefrechtelijke aangelegenheid is, zodat artikel 6 EVRM niet van toepassing is. ${ }^{\text {I04 }}$ Een ander voorbeeld is dat bij het beantwoorden van de vraag of een organisatie een vereniging in de zin van artikel II EVRM is het privaatrechtelijk of publiekrechtelijk karakter naar nationaal recht niet zonder meer beslissend is. ${ }^{\text {I05 }}$ Meer in het algemeen geldt dat het EHRM zich bij de uitleg van de reikwijdte van verdragsbepalingen eerder door overwegingen van materiële aard laat leiden dan door formele onderscheidingen in het nationale recht.

In de verhouding tussen de grondwettelijke grondrechten en het nationale recht zullen zich minder snel begripsmatige divergenties voordoen. Dat is zelfs bij uitstek het geval wanneer, zoals in Nederland, de wetgever zelf de hoofdrol speelt bij de uitleg van de Grondwet.

Het EHRM geeft een dynamische uitleg aan de verdragsbepalingen. Dat impliceert dat de betekenis van de bepalingen niet bij de totstandkoming van het EHRM voor eens en voor altijd is vastgelegd. De Conventie is een 'living instrument (...) which must be interpreted in the light of present-day conditions' ${ }^{\text {IO6 }}$ Het Hof wil zo mogelijk een uitleg van de verdragsbepalingen geven die zorgt voor effectieve bescherming van de verdragsrechten. Gewijzigde omstandigheden kunnen dan ook een reden vormen om, ondanks het belang van rechtszekerheid, af te wijken van eerdere arresten. ${ }^{107}$ Het EHRM erkent dan ook volmondig dat in haar eigen jurisprudentie een ontwikkeling is aan te wijzen, waaruit het dynamische karakter van de Conventie blijkt. $^{\text {I08 }}$

Deze dynamische interpretatie zal over het algemeen neerkomen op een vergroting van de geboden bescherming. ${ }^{\text {IO9 }}$ Bij het zetten van een belangrijke stap in de rechtsontwikkeling zal het Hof zo mogelijk wel naar een zekere 'common ground' in de rechtsorden van de lidstaten zoeken om zijn uitleg op te baseren. Tekent zich in de verschillende staten geleidelijk een zekere consensus af dan is dat dus van beteke-

IoI. Zie uitgebreid Vande Lanotte \& Haeck 2005, p. I75 e.v.

102. Dat geldt niet in dezelfde mate voor artikel I2 EVRM dat zelf uitdrukkelijk naar het nationale recht verwijst.

I03. Zie voor het eerst EHRM I6 juli I97I, Ringeisen v. Austria, Vol. A I3.

I04. O.a. EHRM 23 oktober I985, Benthem v. The Netherlands. Hetzelfde geldt voor de term 'strafvervolging' in artikel 6 EVRM. Bij het opleggen van een administratieve boete gelden daarom in beginsel dezelfde waarborgen als bij het opleggen van een strafrechtelijke boete. Bijv. EHRM I9 november 2004, Falk v. The Netherlands, NJ $2005,429$.

I05. EHRM 29 april I999, Chassagnou and others v. France; EHRM Io oktober 2007, Schneider c. Luxembourg.

Io6. Sinds EHRM 25 april I978, Tyrer v. United Kingdom, een vaste formule.

I07. EHRM 28 mei 2002, Stafford v. United Kingdom.

Io8. Bijv. EHRM 30 juni I993, Sigurjonsson v. Iceland.

I09. Zie voor de vraag of een degressieve ontwikkeling mogelijk is: Vande Lanotte 2005, p. I95. 
nis voor de mogelijke dynamische uitleg van het verdrag. Mede om die reden kwam het Hof in $\mathbf{2 0 0 2}$ tot de conclusie dat de juridische erkenning van een geslachtsverandering inmiddels wél binnen de reikwijdte van artikel 8 EVRM valt. ${ }^{\text {Io }}$

Wanneer er tussen de verdragsstaten grote verschillen bestaan in recht en/of moraal zal het Hof zich, zoals gezegd, terughoudender opstellen. Dat kan geïllustreerd worden aan de hand van de zaak Vo. tegen Frankrijk. Het EHRM moest beoordelen of een ongeboren kind drager is van het recht op leven, en zo ja, vanaf welk moment. $\mathrm{Nu}$ er in de lidstaten geheel verschillend over de (rechts)positie van het ongeboren kind gedacht wordt, constateerde het Hof dat 'the issue of when the right to life begins comes within the margin of appreciation which the Court generally considers that States should enjoy in this sphere'. ${ }^{\text {II }}$ De staten die partij zijn bij het verdrag kunnen deze vraag naar de reikwijdte van het recht op leven op dat punt dus zelf - en verschillend - beantwoorden.

Bij de dynamische uitleg past minder goed een 'wetshistorische uitleg' die in het bijzonder de totstandkoming van de bepaling onderzoekt om de juiste interpretatie te vinden. Overigens bieden de 'travaux préparatoires' ook maar in beperkte mate uitsluitsel over de inhoud van de verdragsbepalingen. ${ }^{\text {II2 }}$ De dynamische uitleg past evenmin goed bij een tekstuele interpretatie, die de eenmaal vastgelegde letter beslissend acht. Dat wil niet zeggen dat deze vorm van interpretatie geheel afwezig is in de jurisprudentie van het Hof, ${ }^{\mathrm{II} 3}$ maar vaker zien we de teleologische interpretatie die het doel of de strekking van de bepaling centraal stelt. ${ }^{\mathrm{II}}{ }^{\mathrm{H}}$ Het uitgangspunt van het Hof is immers dat op grond van de verdragsbepalingen een effectieve bescherming dient te worden gegeven.

Het EHRM leidt bijvoorbeeld uit de strekking van artikel so EVRM af dat het journalistiek brongeheim binnen de reikwijdte valt. ${ }^{\mathrm{II}}$ Een andere interpretatie zou ten koste kunnen gaan van de effectieve vrijheid van meningsuiting en de informatievoorziening aan het publiek. Effectieve vrijheid van vakvereniging impliceert dat onder de reikwijdte van artikel II EVRM niet alleen het recht valt een vakbond op te richten maar ook het recht van een vakbond om allerlei activiteiten te organiseren en

IIo. Het Hof overwoog aanvankelijk dat er ten aanzien van de juridische erkenning van geslachtsverandering geen consensus bestond; dit voor het eerst in EHRM 17 oktober I986, Rees v. United Kingdom, herhaald in EHRM 27 september I990, Cossey v. United Kingdom, EHRM 25 maart I992, B. c. France, en EHRM 30 juli I998, Sheffield en Horsham v. United Kingdom. Het Hof stelde in 2002 echter dat er sprake was van 'clear and uncontested evidence of a continuing international trend in favour not only of increased social acceptance of transsexuals but of legal recognition of the new sexual identity of post-operative transsexuals', EHRM II juli 2002, Goodwin v. United Kingdom.

III. EHRM 8 juli 2004 (GC), Vo. c. France.

II2. Robertson I993. Sommige voorgestelde verdragsbepalingen zijn op het laatste moment ook nog sterk gewijzigd. Zo is het begrip 'privé leven' pas in een laat stadium in artikel 8 EVRM toegevoegd.

II3. Zie bijv. EHRM 29 april 2002, Pretty v. United Kingdom, waarin het Hof stelt dat een recht om te sterven niet onder artikel 2 EVRM gebracht kan worden zonder de bewoordingen geweld aan te doen.

II4. Andere interpretatiemethoden als de systematische en de analoge interpretatie ontbreken evenmin. In dit bestek kan daar niet op ingegaan worden.

II5. EHRM 27 maart I996, Goodwin v. United Kingdom. 
om actie te voeren. ${ }^{\mathrm{II} 6}$ De dynamische en teleologische uitleg van het recht op respect voor het privé leven (artikel 8 EVRM) heeft er onder meer toe geleid dat dit recht ook op het werk betekenis heeft ${ }^{\mathrm{II} 7}$ en ook een zekere bescherming biedt tegen stank en lawaai. ${ }^{\text {II } 8}$ Meer recent heeft het Hof overwogen dat het recht op respect voor het privé leven een beginsel van zelfbeschikking in zich draagt: 'the Court considers that the notion of personal autonomy is an important principle underlying the interpretation of its guarantees'. ${ }^{\text {II }}$ Ook daardoor kan de reikwijdte weer een nieuwe dimensie krijgen. ${ }^{\mathrm{I} 20}$

In de uitleg van de grondwettelijke grondrechten door de Nederlandse rechter komt een dergelijke dynamische, op effectieve bescherming gerichte, ontwikkeling slechts sporadisch naar voren. ${ }^{\mathrm{I} I \mathrm{I}}$ Zo heeft de constructie van een algemeen persoonlijkheidsrecht ${ }^{\mathrm{I22}}$ vooralsnog niet of nauwelijks een vervolg gekregen. Meer in het algemeen geldt weer dat de centrale positie van de wetgever belet dat de Grondwet in de jurisprudentie een sprankelend 'living instrument' is.

\section{Interpretatie clausulering artikel 8-11 EVRM}

De artikelen $8 \mathrm{t} / \mathrm{m}$ II EVRM leggen belangrijke grondrechten vast als het recht op respect voor het privé leven, de vrijheid van godsdienst of overtuiging, de vrijheid van meningsuiting en de vrijheid van vergadering en vereniging. Het tweede lid van deze artikelen stelt telkens een drietal voorwaarden aan een inmenging in de in het eerste lid vastgelegde vrijheden. Inmengingen moeten 'bij de wet zijn voorzien', een van de in het tweede lid genoemde doeleinden te dienen en noodzakelijk in een democratische samenleving te zijn. De term 'wet' betekent hier - anders dan in de Nederlandse Grondwet - niet 'wet in formele zin'. Lagere regelingen, maar ook normen van ongeschreven recht kunnen onder die noemer vallen ${ }^{123}$ Ook een bevoegd gegeven bevel voldoet in beginsel aan deze voorwaarde. ${ }^{24}$ Het EHRM eist wel dat een beperking 'accessible and foreseeable' is: de (mogelijkheid van een) beperking moet voor de burger kenbaar zijn en de beperking moet tot op zekere hoogte te voorzien zijn.

II6. EHRM 25 appril I996, Gustafsson v. Sweden. De nadruk op 'effectieve vrijheid' komt overigens terug bij de wijze waarop het Hof beperkingen beoordeelt. Het Hof schenkt daarbij veelal nadrukkelijk aandacht aan het al dan niet bestaan van alternatieve mogelijkheden om een bepaalde vrijheid uit te oefenen.

II7. EHRM I6 december I992, Niemietz v. Germany.

II8. EHRM 9 december 1994 Lopez Ostra v. Spain; EHRM 7 augustus 2003 (GC), Hatton v. United Kingdom.

II9. EHRM 29 april 2002, Pretty v. United Kingdom.

I20. Aan dit beginsel wordt onder meer gerefereerd in EHRM I7 februari 2005, K.A. \& A.D. c. Belgique.

I2I. Een mogelijk voorbeeld vormt de uitbreiding van de bescherming van de woning (artikel I2 Grondwet) tot een hotelkamer, zie Hof Den Haag 9 juni 1983 , geciteerd in: HR 29 mei I 984 , DD I 984,455 en 457 .

I22. HR I5 april I994, NJ I994, 608; HR 6 januari I995, NJ I995, 422; HR I juli I997, NJ I997, 685. Zie ook Nehmelman 2002.

I23. EHRM 26 april I979, Sunday Times v. United Kingdom.

I24. Bijv. EHRM 4 juni 2002, Olivieira v. The Netherlands. Ook in de Nederlandse jurisprudentie worden beperkingen gebaseerd op een bevoegd genomen beschikking van een bestuursorgaan geaccepteerd, zie al HR 25 juni I982, NJ I983, 296. Datzelfde geldt vermoedelijk in bepaalde omstandigheden zelfs voor beperkingen gebaseerd op beleidsregels. Zie ARRvS ro januari I983, $A B$ I983, 306 inzake artikel I2 IVBPR, dat ook de eis van 'bij de wet voorzien' kent. 
De vereisten impliceren overigens niet dat een regeling geen vage termen mag bevatten. Dat mag indien de jurisprudentie daar invulling aan heeft gegeven. ${ }^{\mathrm{I} 25}$ Ook een zekere beleidsvrijheid voor het bestuur is acceptabel. ${ }^{126} \mathrm{Op}$ bepaalde terreinen geeft het EHRM de eisen een meer specifieke invulling. De bevoegdheid om telefoons te tappen dient bijvoorbeeld niet alleen duidelijk omschreven te zijn, zodat er geen misverstand bestaat over de vraag welk orgaan in welke gevallen tot tappen kan besluiten en hoe lang dat is toegestaan, ${ }^{\mathrm{I} 27}$ maar er dient ook een adequate controle op de uitoefening van dergelijke bevoegdheden te bestaan. Anders is de regeling kwalitatief onvoldoende.

De tweede voorwaarde is dat een beperking een legitiem doel dient. Dat vereiste heeft maar een beperkte waarde. In de eerste plaats kennen artikel $8 \mathrm{t} / \mathrm{m}$ II EVRM een reeks van doeleinden die bovendien niet strikt worden uitgelegd. ${ }^{\mathrm{I} 28}$ In de tweede plaats komt de vraag of de beperking werkelijk het gestelde doel dient, veelal pas aan de orde bij de voorwaarde dat de beperking noodzakelijk dient te zijn in een democratische samenleving. Indien de regering in Straatsburg stelt dat de beperkende maatregelen een in lid 2 genoemd doel dienen, is daarom al snel aan deze voorwaarde voldaan.

Het zwaartepunt van de beoordeling ligt meestal bij de vraag of een beperking noodzakelijk is in een democratische samenleving. 'Noodzakelijk' is meer dan 'wenselijk', zonder dat het als 'onmisbaar' hoeft te worden begrepen. ${ }^{129}$ Het komt erop neer dat de in het geding zijnde beperking proportioneel moet zijn, ${ }^{130}$ een eis die veelal vergezeld gaat van de eis dat er een dringende maatschappelijke noodzaak ('pressing social need') voor de beperking bestaat. In elk geval dienen er steeds relevante en voldoende redenen ('relevant and sufficient reasons') voor een beperking te zijn. ${ }^{\text {I3I }}$

De noodzakelijkheidstoets impliceert dat er steeds een afweging gemaakt dient te worden tussen het belang gemoeid met de beperking en het belang van het grondrecht. ${ }^{132}$ Daarbij heeft het EHRM een meer algemeen kader geschapen, waaruit

I25. EHRM 26 april I979, Sunday Times v. United Kingdom; EHRM 20 november I989, NJ I99I, 738, Markt intern v. Germany; ECieRM 2I oktober I998, Mediaforum I999-I, nr. 3, Het Parool v. Nederland.

I26. O.a. EHRM I7 februari 2004 (GC), Gorzelik and others v. Poland; EHRM 4 juni 2002, Olivieira v. The Netherlands.

I27. O.a. EHRM 24 april I990, Huvig c. France, en EHRM 24 april I99o, Kruslin c. France.

I28. We zien voorbij aan de onderlinge verschillen tussen de in de genoemde artikelen vastgelegde legitieme doeleinden.

I29. EHRM 7 december I976, Handyside. v. United Kingdom.

I30. Zie voor dit begrip onder meer McBride I999; Van Drooghenbroeck 200I; Nieuwenhuis, Schueler \& Zoethout 2005 .

I3I. EHRM 7 december I976, Handyside. v. United Kingdom.

I32. De afweging op grond van de noodzakelijkheidstoets vindt over het algemeen in concreto plaats, zodat alle specifieke omstandigheden van het geval een rol kunnen spelen. Dat sluit niet uit dat het EHRM een regeling als zodanig in strijd acht met een verdragsbepaling. Dat doet zich bijvoorbeeld voor indien de regeling zelf als een bedreiging wordt gezien van een van de verdragsrechten. Bijv. EHRM 22 oktober I98I, Dudgeon v. United Kingdom. Voorts is het mogelijk dat uit de beoordeling van de casus blijkt dat toepassing van een regel vrijwel steeds in strijd zal zijn met een verdragsbepaling. Een voorbeeld vormt een nationaalrechtelijk vereiste dat waardeoordelen bewezen dienen te worden om een veroordeling wegens belediging te ontlopen, EHRM 8 juli I986, Lingens v. Austria. Ten slotte komt het ook voor dat het EHRM de beperking in het concrete geval misschien nog wel acceptabel zou achten, maar de regel waarop deze beperking gebaseerd is te ver vindt gaan, EHRM 6 oktober 2005 (GC), Hirst v. United Kingdom; zie hierover ook Vlemminx 2007, p. 322-329; vgl ook EHRM 24 juni 2008, Adamsons c. Lettonie. 
bijvoorbeeld blijkt welke beperkingen als ernstiger zijn te kwalificeren of zelfs de kern van het grondrecht raken. Zo is een beperking van het maatschappelijke debat ernstiger dan een beperking die alleen (commerciële) reclame treft. De voor de beperking aangevoerde redenen zullen in het eerste geval dan ook een relatief zwaar gewicht dienen te hebben. Wanneer een parlementariër gesanctioneerd wordt wegens kritiek op de regering komen we zelfs in de buurt van de kern van artikel to EVRM. ${ }^{\mathrm{I} 3}$ De kern van artikel 8 wordt onder meer geraakt indien verbodsbepalingen ingrijpen in de intieme sfeer van 'consenting adults'. ${ }^{\text {I34 }}$

Naast de afweging in eigenlijke zin let het EHRM onder omstandigheden ook op de geschiktheid van de beperking om het gestelde doel te bereiken en op de vraag of niet een minder vergaande beperking mogelijk is die hetzelfde effect kan bereiken. Een beperking die niet geschikt is om dat doel te dienen ${ }^{\mathrm{I}} 35$ of een nodeloos vergaande beperking ${ }^{136}$ kan immers niet als noodzakelijk in een democratische samenleving worden beschouwd. In het laatste geval wordt de proportionaliteit in enge zin dus aangevuld met het vereiste van subsidiariteit. ${ }^{\mathrm{I}}{ }^{\mathrm{I}}$

De clausulering van de in artikel $8 \mathrm{t} / \mathrm{m}$ II EVRM vastgelegde bepalingen is dus anders dan die in de Grondwet in belangrijke mate materieel van aard. Niet de bevoegdheden van de formele wetgever staan centraal, maar de vraag of een beperking proportioneel is. Dit vereiste van proportionaliteit speelt overigens ook in jurisprudentie ten aanzien van de uitleg van tal van andere verdragsbepalingen een belangrijke rol. Bij de beoordeling op grond van artikel 2 EVRM van het gebruik van politiegeweld, bij beperkingen van de vrijheid van eigendom (artikel $\mathrm{I}, \mathrm{I}^{\mathrm{e}}$ Protocol) en de bewegingsvrijheid (artikel 2, 4 e Protocol) ligt dat ook voor de hand nu deze bepalingen zelf een (soort) 'noodzakelijkheidstoets' voorschrijven. ${ }^{138}$ De eis van een juiste afweging van belangen komt echter ook naar voren in arresten van het EHRM op grond van tal van andere bepalingen. Wij noemen het oordeel of een onderscheid in behandeling in strijd is met het verbod van discriminatie, ${ }^{139}$ het oordeel of het belang van efficiënte handhaving van verkeersregels onder omstandigheden het presumptio innocentiaebeginsel mag beperken, ${ }^{140}$ het oordeel of de behandeling van een - bijvoorbeeld vluchtgevaarlijke of mogelijkerwijs suïcidale - gevangene zich onder omstandigheden nog verdraagt met artikel 3 EVRM. ${ }^{\text {I4I }}$ Het vereiste van proportionaliteit is zo begrepen een verbijzondering van de notie dat op grond van het verdrag een evenwicht tussen individuele rechten en algemeen belang gezocht moet worden. ${ }^{\mathrm{I}}{ }^{2}$

I33. EHRM 23 april I992, Castells v. Spain.

I34. EHRM 22 oktober I98I, Dudgeon v. United Kingdom.

I35. EHRM 26 november I99I, Observer \& Guardian v. United Kingdom.

I36. EHRM 24 november I993, Informationsverein Lentia v. Austria.

I37. Zie bijv. ook EHRM 28 januari 2003, Peck v. United Kingdom.

I38. Waarbij de toets veelal minder strikt is dan bij artikel $8 \mathrm{t} / \mathrm{m}$ II EVRM.

I39. Vande Lanotte \& Haeck 2005, p. II2; EHRM 2I februari I997, NJ I997, 580, Van Raalte v. The Netherlands.

I40. EHRM ig oktober 2004, Falk v. The Netherlands (admiss. decision), NJ 2005, 429.

I4I. Bijv. EHRM I juni 2004, Van der Graafv. The Netherlands (admiss. decision).

I42. Vande Lanotte \& Haeck 2005, p. 201. 
Appreciatiemarge

Wanneer het EHRM een beperking van een grondrecht beoordeelt, kent het de staten veelal een appreciatiemarge toe: 'a latitude a government enjoys in evaluating factual situations and in applying the provisions enumerated'. ${ }^{43}$ De doctrine van de appreciatiemarge is in de jurisprudentie langzaam opgekomen. De term 'marge' vinden we voor het eerst in de rapporten van de inmiddels opgeheven Commissie: 'Si une mésure étatique reste en dedans de cette marge, elle est en principe conforme à la

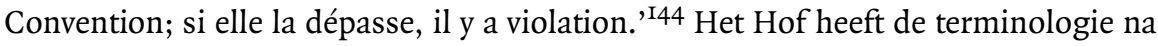
verloop van tijd overgenomen, na overigens ook de term 'pouvoir d'appréciation' te hebben gehanteerd. ${ }^{\text {I45 }}$ De doctrine maakt vervolgens vrij snel school in de jurisprudentie van het Hof, onder meer in arresten met betrekking tot de artikelen 8 en ro EVRM. Zo maakt het Hof in het arrest Handyside duidelijk dat er in casu een betrekkelijk grote appreciatiemarge bestaat nu in Europa een uniforme 'conception of morals' ontbreekt. De nationale autoriteiten, die in contact staan met de 'vital forces of their countries' bevinden zich in een betere positie om een oordeel over de moraal te geven. Dat wil niet zeggen dat controle door het EHRM ontbreekt: 'The domestic margin of appreciation thus goes hand in hand with a European supervision. ${ }^{\text {' } 46}$

De appreciatiemarge berust op een tweetal grondslagen. ${ }^{\mathrm{I}} 47$ In de eerste plaats, zo blijkt ook uit artikel I EVRM, is het voorkómen van schendingen primair een taak van de staten zelf. ${ }^{\mathrm{I}}{ }^{8}$ De controle door de internationale rechter heeft dus een subsidiair karakter. ${ }^{\text {I49 }}$ In de tweede plaats bevinden de nationale autoriteiten zich in sommige gevallen in een betere positie om vast te stellen welke maatregelen geboden kunnen zijn. Dat geldt zeker indien er een Europese standaard ontbreekt of op complexe beleidsterreinen. Beide grondslagen staan overigens niet los van elkaar: is er bijvoorbeeld een duidelijke Europese (minimum)norm, dan zal het EHRM zich genoodzaakt zien deze strikt te handhaven als de nationale autoriteiten in gebreke blijven.

De appreciatiemarge speelt onder meer een rol bij de uitleg van vage termen als 'public emergency', bij het toepassen van de noodzakelijkheidstoets en bij het invullen van positieve verplichtingen. ${ }^{150} \mathrm{Bij}$ het vaststellen van de omvang van de

I43. Takahashi 2002, p. 2; vgl. Vande Lanotte \& Haeck 2005, p. 204: 'de interpretatieruimte waarover staten beschikken met betrekking tot de wijze waarop zij verdragsrechten implementeren en met betrekking tot de evaluatie van feitelijke situaties'.

I44. Rapport van de ECieRM, opgenomen in EHRM 23 juli I968 (Belgian language cases). In een zeer vroege zaak liet de Commissie de nationale autoriteiten ook een zekere ruimte voor een zelfstandig oordeel bij het nemen van maatregelen tijdens noodtoestanden: 'a certain measure of discretion in assessing the extent strictly required by the exigencies of the situation'. Zaak $176 / 6_{5}$, II, p. 174 (Cyprus) Zie ook het oordeel van de Commissie in Lawless v. Ireland 1960, aangehaald in EHRM I juli ig6r, Lawless v. Ireland.

I45. EHRM I8 juni I97I, De Wilde, Ooms \& Versyp c. Belgique.

I46. EHRM 7 december 1976 , Handyside v. United Kingdom.

I47. Schokkenbroek I990, p. 4I-58. Zie ook Schokkenbroek I996, p. 206 e.v.

I48. Het bestaan van een appreciatiemarge heeft voorts tot gevolg dat de verdragsbepalingen met enige flexibiliteit kunnen worden toegepast; in bepaalde precaire gevallen kan een confrontatie tussen de supranationale rechter en de nationale autoriteiten worden voorkomen, Takahashi 2002, p. 3 e.v.

I49. Vande Lanotte \& Haeck 2005, p. I79.

I50. Uiteraard kan er ook sprake zijn van een combinatie van factoren. In het Handyside arrest ging het om een afweging, en om de bescherming van de moraal. 
appreciatiemarge is een aantal factoren van belang: 'Relevant factors include the nature of the Convention right in issue, its importance for the individual and the nature of the activities concerned.' ${ }^{\text {I }}$ Daar kan het doel van de beperking aan worden toegevoegd. ${ }^{152}$

De marge speelt maar een beperkte rol bij de artikelen 2, 3 en 4 en bij veel aspecten van artikel 5 en artikel 6 EVRM. ${ }^{153}$ Soms rept het Hof overigens evenmin over een appreciatiemarge wanneer het een oordeel geeft over beperkingen van rechten vastgelegd in artikel $8 \mathrm{t} / \mathrm{m}$ II EVRM. Dat is onder meer het geval wanneer het een schending evident acht. ${ }^{154}$ Wanneer er activiteiten verboden worden die tot het kernbereik van het grondrecht horen, is er eveneens weinig reden om de nationale autoriteiten een ruime marge te gunnen. ${ }^{155}$ Indien het maatschappelijke debat ingeperkt wordt is de supervisie door het EHRM bijvoorbeeld minder afstandelijk dan wanneer beperkingen zien op reclame. Hebben beperkingen te maken met de nationale veiligheid of openbare orde, ${ }^{156}$ of vormen zij een onderdeel van het complexe sociaal-economische of planologische beleid, dan zal de marge al snel groter zijn. ${ }^{\text {I57 }}$ Datzelfde geldt wanneer moraal de beperkingsgrond vormt. Op dat gebied ontbreekt namelijk een Europese standaard. Die bestaat evenmin wat betreft de verhouding tussen kerk en staat. Deze verschilt sterk in Europa en daarom laat het EHRM een beduidende marge aan de nationale autoriteiten. ${ }^{158}$

De verschillen in omvang van de marge die het EHRM de nationale organen laat, zijn voor een deel ook te verklaren door de verbinding tussen grondrechten en democratie, die ook naar voren komt uit de eis dat beperkingen noodzakelijk zijn in een democratische samenleving. Is er een sterke verbinding tussen het betreffende grondrecht en de democratie, dan zal de appreciatemarge klein zijn. De persvrijheid bijvoorbeeld verdient in iedere democratie een grote mate van bescherming. Uit het democratiebegrip volgt daarentegen niet simpelweg wat de juiste verhouding tussen kerk en staat is. De marge zal op dat gebied groter zijn. ${ }^{159}$

De nationale autoriteiten kunnen ook het beste zelf vaststellen wat het algemeen belang is. De marge bij een oordeel op grond van artikel $\mathrm{I}, \mathrm{I}^{\mathrm{e}}$ Protocol zal alleen al daarom gemiddeld groter zijn dan bij een oordeel op grond van artikel $8 \mathrm{t} / \mathrm{m}$ II EVRM: 'Because of their direct knowledge of their society and its needs, the national authorities are in principle better placed than the international judge to appreciate what is "in the public interest".' Een belangrijke reden is weer dat er in een democratie op dit terrein geen eenduidige opvattingen hoeven te bestaan: ' ( ...) the decision

\footnotetext{
I5I. EHRM 25 september 1993, Buckley v. United Kingdom (par. 74), o.a. aangehaald in EHRM 7 augustus 2003 (GC), Hatton v. United Kingdom (par. Ior).

I52. O.a. EHRM 7 december 1976 , Handyside v. United Kingdom.

I53. Barkhuysen 2004, p. 42. Vgl. Vande Lanotte \& Haeck 2005, p. 2 I4.

I54. Schokkenbroek 1996, p. 219.

I55. Dat zelfde geldt voor onderscheid op grond van ras of sekse, beoordeeld op grond van artikel I4 EVRM, bijv. EHRM 28 mei I985, Abdulaziz, Cabales \& Balkandali v. United Kingdom.

I56. Bijv. 25 augustus 1993, Chorherr v. Austria; EHRM 4 juni 2002, Olivieira v. The Netherlands.

I57. Bijv. EHRM 20 november I989, Markt Intern Verlag \& Klaus Beermann v. Germany; EHRM 24 juni 2004, Vergos v. Greece.

I58. EHRM 29 juni 2004, Leyla Sahin v. Turkey.

I59. EHRM 29 juni 2004, Leyla Sahin v. Turkey.
} 
to enact laws expropriating property will commonly involve consideration of political, economic and social issues on which opinions within a democratic society may reasonably differ widely. ${ }^{\mathrm{I} 60}$

De appreciatiemarge kan de intensiteit van de door het EHRM gehanteerde proportionaliteitstoets aanmerkelijk verminderen. ${ }^{\text {I6I }}$ De bevoegdheid om de noodzakelijkheid van een beperking te beoordelen wordt namelijk in eerste instantie bij de nationale autoriteiten gelegd: 'It is for the national authorities to make the initial assessment of the necessity. ${ }^{\text {I62 }}$ Dat geldt ook voor de vraag of er een 'pressing social need' bestaat. ${ }^{163}$ De grootte van de toegekende marge bepaalt hoe stringent het Hof de beperking en daarmee de beslissing van de nationale autoriteiten toetst. Toekenning van een bepaalde marge en beoordeling van de proportionaliteit kunnen overigens dooreenlopen. ${ }^{\mathrm{I} 64}$ In de literatuur komt men op grond van de geschetste samenhang wel het oordeel tegen dat de toekenning van een marge en de beoordeling van de proportionaliteit van hetzelfde laken een pak zijn. ${ }^{165}$ Dat is juist voorzover de ernst van een beperking zowel tot een smalle marge kan leiden als tot de eis dat er zwaarwegende redenen voor de beperking zijn.

$\mathrm{Nu}$ het EHRM beoordeelt of de staat een bepaling van het verdrag heeft geschonden, hoeft het zich niet uit te laten over de vraag welk specifiek orgaan de appreciatiemarge toekomt. Het Hof heeft zelf aangegeven dat onder 'de nationale autoriteiten' zowel de wetgever als andere 'bodies, judicial among others; that are called to interpret the law' kunnen vallen. ${ }^{\mathrm{I}}{ }^{6}$ Indien een bepaald orgaan in het bijzonder verantwoordelijk is voor een bepaalde inmenging, lijkt het EHRM soms specifieker. In bepaalde arresten vinden we speciaal aandacht voor de ruimte voor de wetgever: 'the Court points out that the domestic legislature enjoys a certain discretion'. ${ }^{167}$ In andere gevallen lijkt het EHRM er eerder van uit te gaan dat bestuursorganen enige ruimte toekomt. ${ }^{\text {I68 }}$ Indien de inmenging in het bijzonder voortvloeit uit een uitspraak van de rechter, oordeelt het Hof of de beslissing van de rechter de marge niet te buiten is gegaan: 'It is primarily for the national courts to decide what statements are permissible. It cannot be said that the final decision of the Federal Court went beyond the margin of appreciation left to the national authorities. ${ }^{\text {I69 }}$

I6o. EHRM 2I februari I986, James and others v. United Kingdom.

I6I. McBride I999, p. 29.

I62. Bijv. EHRM 25 september I996, Buckley v. United Kingdom.

I63. Bijv. EHRM 7 december I976, Handyside v. United Kingdom.

I64. Een goed voorbeeld is EHRM 25 februari I987, Leander v. Sweden.

I65. Takahashi 2002, p. I5.

I66. Bijv. EHRM 7 december I976, Handyside v. United Kingdom.

I67. EHRM 6 september 1978 , Klass and others v. Germany.

I68. EHRM 25 september I996, Buckley v. United Kingdom.

I69. EHRM 20 november I989, Markt Intern Verlag \& Klaus Beermann v. Germany. 
Positieve verplichtingen

Bij de totstandkoming van het verdrag was de algemene opvatting dat daarin bij uitstek onthoudingsplichten waren opgenomen. ${ }^{170}$ Dat mag overigens niet verhullen dat de overheid op grond van de bewoordingen van artikel 5 en 6 EVRM gehouden was actief bepaalde waarborgen te bieden. ${ }^{\text {17I }}$ De dynamische rechtsvorming door het Hof, dat streeft naar een effectieve bescherming, heeft er echter voor gezorgd dat nu alle onthoudingsplichten in beginsel vergezeld gaan van positieve verplichtingen. ${ }^{172}$

In deze ontwikkeling is het Marckx-arrest van het Hof een belangrijke stap geweest. ${ }^{173}$ Het Hof overweegt dat artikel 8 EVRM ook 'positieve obligations inherent in an effective "respect" for family life' met zich mee kan brengen. In deze zaak stelt het Hof overigens een schending van artikel 8 jo. 14 EVRM vast en niet een schending van een positieve verplichting op grond van artikel 8 EVRM. ${ }^{174}$ De zaak Airey waarin het Hof spreekt over een 'obligation to secure an effective right' and over 'positive action' van de kant van de staat, ${ }^{175}$ mag als een verdere aanzet gelden. Van belang is ook de zaak X and Y v. the Netherlands, die zag op een lacune in de Nederlandse strafvorderlijke regelgeving, waardoor de mogelijke dader van een verkrachting van een handelingsonbekwame minderjarige niet vervolgd kon worden. Het Hof overweegt dat:

'although the object of Article 8 is essentially that of protecting the individual against arbitrary interference by the public authorities, it does not merely compel the State to abstain from such interference: in addition to this primarily negative undertaking, there may be positive obligations inherent in an effective respect for private and family life (...)'. ${ }^{176}$

Sindsdien zijn ook tal van andere verdragsbepalingen van positieve verplichtingen voorzien. Deze verplichtingen kunnen bestaan uit het door de overheid treffen van regelingen, uit het geven van informatie, uit het doen van onderzoek naar mogelijke schendingen, etc. ${ }^{177}$ Positieve verplichtingen zijn soms duidelijk omschreven, ${ }^{178}$ maar in andere gevallen heeft de overheid een zekere vrijheid om de maatregelen te kiezen waarmee aan een positieve verplichting kan worden voldaan. ${ }^{\mathrm{I} 9}$ Neemt de overheid in het geheel geen maatregelen dan zal het EHRM kunnen constateren dat

I70. Teitgen I993, p. II.

I7I. Vgl. Mowbray 2004, p. I90. De bewoordingen van artikel 3, Eerste Protocol, waarin het recht op vrije verkiezingen is vastgelegd, benadrukken eveneens het vereiste van positieve maatregelen, zie EHRM 2 maart I987, Mathieu-Mohin \& Clerfayt v. Belgium.

172. Vande Lanotte \& Haeck 2005, p. 99.

I73. EHRM I3 juni i979, Marckx v. Belgium.

I74. Vgl. Vande Lanotte \& Haeck 2004a, p. 740.

I75. EHRM 9 oktober 1979, Airey v. Ireland.

I76. EHRM 27 februari 1985, X. \& Y. v. The Netherlands.

I77. Vgl. Mowbray 2004.

178. Zo stelt EHRM 30 november 2004, Öneryildiz c. Turkey, de eis van strafvervolging; zie bijv. ook EHRM I5 mei 2007 (GC), Ramsahai v. The Netherlands, ten aanzien van de onderzoeksplicht na een dode door politiegeweld.

I79. Soms is een positieve verplichting ook vooral als een inspanningsverplichting te beschouwen EHRM 2I juni I988, Plattform ‘Ärzte für das Leben’ v. Austria. 
de positieve verplichtingen geschonden zijn wegens het uitblijven van 'appropriate measures' zonder deze precies te omschrijven. ${ }^{180}$ Daar staat tegenover dat de overheid niet tot het (technologisch) onmogelijke is gehouden. ${ }^{\text {I8I }}$

Positieve verplichtingen kunnen de staat er onder meer toe verplichten om te zorgen voor bescherming van het grondrecht tegen particulieren. Deze bescherming die in de nationale context als horizontale werking van het grondrecht wordt aangeduid, kan wederom tal van vormen aannemen. In sommige gevallen zal het privaatrecht zodanig moeten worden uitgelegd dat het voldoende bescherming aan de privacy biedt, ${ }^{182}$ in andere gevallen dient een ernstige inbreuk door een burger gemaakt op het recht op lichamelijke integriteit ook strafrechtelijk gesanctioneerd te kunnen worden. ${ }^{183}$ In weer andere gevallen zal het bestuur bepaalde maatregelen moeten nemen om demonstranten tegen een 'hostile audience' te beschermen. ${ }^{\text {I }} 4$

Bij de beoordeling van de vraag of een staat zijn positieve verplichtingen op grond van artikel $8 \mathrm{t} / \mathrm{m}$ II EVRM heeft geschonden, is het tweede lid van deze bepalingen in toenemende mate relevant geworden. ${ }^{85}$ De wijze waarop beoordeeld wordt of de staat voldoende heeft gedaan om bijvoorbeeld inmenging door particulieren tegen te gaan is tegenwoordig in belangrijke mate vergelijkbaar met de beoordeling of de onthoudingsplicht is geschonden. ${ }^{\mathrm{I}}{ }^{86}$ Het komt er in veel gevallen op neer dat het EHRM onderzoekt of er een 'fair balance' is getroffen tussen de relevante belangen.

De positieve verplichtingen zijn om een aantal redenen interessant. In de eerste plaats zal het vernietigen van een besluit of het buiten toepassing laten van een wettelijk voorschrift door de rechter veelal niet voldoende zijn om de uit een positieve verplichting voortvloeiende waarborg te bieden. Het is in het bijzonder de vraag of de rechter effectieve rechtsbescherming kan bieden indien de wettelijke basis om aan een positieve verplichting te voldoen ontbreekt. Wij komen daarop terug bij de uiteenzetting van de rechtsvormende taak.

In de tweede plaats zijn de positieve verplichtingen interessant omdat zij onder omstandigheden ook de plicht kunnen inhouden een - ander - in het verdrag vastgelegd grondrecht te beperken. ${ }^{187}$ In het bekende Von Hannover arrest, waarin de publicatie van foto's van prinses Caroline van Monaco, onder meer gemaakt bij het winkelen, in het geding was, komt het Hof tot het oordeel dat de nationale rechter

I8o. Bijv, EHRM 20 januari 2006, Ouranio Toxo v. Greece.

I8I. EHRM I3 november 2007, Muscio c. Italie (recev.). Het betrof de mogelijke verplichting op grond van art. 8 EVRM om op te treden tegen pornospam.

I82. EHRM 24 juni 2004, Von Hannover v. Germany.

I83. EHRM 26 maart 1985 , X en Y v. The Netherlands.

I84. EHRM 2I juni I988, Plattform ‘Ärzte für das Leben’ v. Austria.

I85. EHRM 7 augustus 2003 (GC), Hatton v. United Kingdom.

I86. Vgl. Van Dijk e.a. (ed.) 2006, p. 745: 'broadly similar'.

I87. In andere gevallen is er niet zozeer sprake van 'botsing' van verschillende grondrechten maar van een casus waarin beide partijen zich - bij de nationale rechter - op hetzelfde grondrecht kunnen beroepen. Men denke aan bepaalde familierechtelijke zaken waarin beide partijen een beroep op artikel 8 EVRM kunnen doen. Ook bij de vrijheid van vereniging kan zich een dergelijke botsing binnen een grondrecht voordoen. In die gevallen geldt dat een te ruime bescherming van een in het verdrag vastgelegd recht in strijd kan komen met datzelfde verdragsrecht. 
een verkeerde afweging heeft gemaakt tussen privacy en persvrijheid. In casu had het Duitse recht de bescherming van de privacy van de prinses voorrang moeten geven. ${ }^{\mathrm{I} 88}$ Inmiddels is het Hof ook in de zaak Pfeiffer ${ }^{189}$ tot het oordeel gekomen dat het nationale recht een te grote bescherming bood aan de persvrijheid. Oostenrijk had zijn positieve verplichting om het recht op respect voor het privé leven te beschermen geschonden, nu het Oostenrijkse recht geen bescherming bood aan een journalist, die er in de media van beticht was dat hij een extreemrechtse politicus 'tot zelfmoord had gedreven' met zijn berichtgeving over deze politicus.

Deze ontwikkeling relativeert het uitgangspunt dat een staat op basis van nationale grondrechtenbepalingen altijd meer bescherming mag bieden dan op grond van de verdragsbepaling is voorgeschreven (vgl. artikel 53 EVRM). Bij een botsing tussen persvrijheid en - de positieve verplichtingen ten aanzien van - het recht op respect voor het privé leven is er veeleer sprake van een bandbreedte waarbinnen het nationale recht zich mag bewegen. Het nationale recht mag immers enerzijds de persvrijheid niet te zeer beperken om niet in strijd te geraken met de in artikel ro EVRM vastgelegde onthoudingsplicht, maar moet anderzijds de persvrijheid ook grenzen stellen om te voldoen aan de op grond van artikel 8 EVRM bestaande positieve verplichtingen. De genoemde bandbreedte zal mede afhangen van de appreciatiemarge die het EHRM de nationale autoriteiten laat bij de afweging tussen het belang van de persvrijheid en de privacy. Deze bandbreedte lijkt in de zaak Von Hannover niet zeer groot te zijn.

Het betoog in dezen is toegespitst op de botsing tussen persvrijheid en privacy, maar ook bij andere botsingen, zoals tussen de persvrijheid en de presumptio innocentiae en tussen de vrijheid van meningsuiting en de vrijheid van godsdienst, ${ }^{190} \mathrm{zal}$ een dergelijke bandbreedte voor het nationale recht kunnen ontstaan. ${ }^{\text {I9I }}$ In het laatstgenoemde geval zal deze bandbreedte waarschijnlijk relatief groot zijn. Enerzijds zal godsdienstkritiek niet snel verboden mogen worden ${ }^{192}$ en anderzijds mag worden aangenomen dat een staat de positieve verplichting heeft om bescherming te bieden tegen oproepen tot geweld of tegen oproepen om groepen gelovigen het land uit te zetten. ${ }^{193}$ Het antwoord op de vraag, of het spotten met belangrijke godsdienstige symbolen of figuren verboden of toegestaan moet zijn, zal echter in belangrijke mate binnen die bandbreedte vallen en kan dus per staat aanzienlijk verschillen. ${ }^{\text {I94 }}$

I88. EHRM 24 juni 2004, Von Hannover v. Germany.

I89. EHRM I5 november 2007, Pfeiffer v. Austria.

I90. Deze botsing zal zich overigens vooral ook dan voordoen wanneer men er met het EHRM vanuit gaat dat het recht op vrijheid van godsdienst ook een recht inhoudt gevrijwaard te blijven van - bepaalde kwetsende uitlatingen, EHRM 20 september I994, Preminger v. Austria. Het is ons inziens de vraag of het recht op vrijheid van godsdienst daarmee niet een te zware lading krijgt, en nog wel strookt met het uitgangspunt dat de vrijheid van meningsuiting ook geldt voor uitlatingen die 'heurtent choquent ou inquiètent', zie ook de dissenting opinion in EHRM $\mathrm{I}_{3}$ september 2005, I.A. c. Turquie.

I9I. Nieuwenhuis 2008.

I92. EHRM 3I januari 2006, Giniewski c. France.

193. De oproep om aanhangers van een bepaald geloof het land uit te zetten kan in elk geval als misbruik van grondrecht (artikel I7 EVRM) worden beschouwd, EHRM I6 november 2004 (admiss. decision), Norwood v. United Kingdom.

I94. Vgl. ook Lawson 2008, p. 469-484. 


\subsection{De Nederlandse rechter en de jurisprudentie van het EHRM}

In de inleiding is reeds vastgesteld dat de materiële bepalingen van het EVRM een ieder verbindend zijn. Dus hebben ze verbindende kracht in de Nederlandse rechtsorde en kan de Nederlandse rechter nationale wettelijke voorschriften eraan toetsen. In deze paragraaf wordt eerst onderzocht welke status de uitleg van de verdragsbepalingen door het EHRM in de Nederlandse rechtsorde heeft. Vervolgens worden twee kwesties nader onderzocht, namelijk de vraag, of de Nederlandse rechter op grond van het EVRM meer bescherming mag bieden dan waartoe hij op grond van de jurisprudentie van het EHRM is verplicht, en de vraag, of de rechter bij het bieden van rechtsbescherming op grond van het EVRM niet in voorkomende gevallen stuit op de grenzen van zijn rechtsvormende taak. In het verlengde daarvan ligt de vraag of het eventueel 'abstineren' door de rechter, het bewust ervan afzien om zelf in een rechtstekort te voorzien, niet leidt tot strijd met de verdragsverplichtingen.

\section{Doorwerking jurisprudentie EHRM}

De vraag hoe de jurisprudentie van het Hof doorwerkt in de Nederlandse rechtsorde is in het verleden op twee manieren beantwoord. ${ }^{195}$ De eerste is dat de uitspraken van het EHRM in zaken tegen Nederland besluiten van een internationale organisatie zijn in de zin van artikel 93 en 94 Grondwet en als zodanig doorwerken in de Nederlandse rechtsorde. Een dergelijke opvatting strookt met artikel 46 lid I EVRM, waarin is bepaald dat de verdragspartijen gebonden zijn aan de tegen hen gewezen arresten.

De andere opvatting gaat ervan uit dat de uitleg van de verdragsbepalingen die het EHRM in zijn arresten geeft, is geïncorporeerd in de verdragsbepaling waarop zij betrekking hebben. ${ }^{196}$ Het gevolg is dat ook de tegen andere staten gewezen arresten op grond van artikel 93 en 94 Grondwet onmiddellijk doorwerken binnen de Nederlandse rechtsorde. De jurisprudentie van de Hoge Raad geeft sinds zijn arrest van Io november 1989 uitdrukkelijk steun aan de opvatting dat Nederland ook buiten de grenzen van het huidige artikel 46 EVRM gebonden is aan uitspraken van het EHRM. ${ }^{197}$ In een arrest van I2 september 1997 vinden we de overweging dat een wettelijk voorschrift buiten toepassing gelaten moet worden, indien de toepassing in strijd is met artikel 6 EVRM, 'zoals deze verdragsbepaling blijkens de rechtspraak van het EHRM moet worden begrepen', daarbij uitdrukkelijk verwijzend naar het arrest Borgers tegen België. ${ }^{198}$ Ook in andere gevallen is de Hoge Raad soms vrij snel - al dan niet contrecoeur ${ }^{199}$ - overstag gegaan na een niet tegen Nederland gewezen arrest.

De tweede opvatting over de wijze van doorwerking van de jurisprudentie moet derhalve als juist beschouwd worden. Zij spoort ook beter met bepaalde arresten van het EHRM waarin het een uitleg van een verdragsbepaling geeft met het uitdrukke-

I95. Doorduijn I994, p. I e.v. Vgl. ook Alkema I985, p. 3 I.

I96. Vgl. Hey, De Lange \& Mevis 2005, p. 6.

I97. HR Io november I989, NJ 1990, 628; zie hierover Martens 200ob, p. 755. Vgl. HR ro mei I996, NJ I996, 578; HR I2 september I997, RvdW I997, i68.

I98. HR I2 september I997, RudW I997, I68; EHRM 30 oktober I99I, Borgers v. Belgium.

I99. Vgl. Martens 200ob, 757-758. 
lijke doel dat er in de lidstaten een gelijke bescherming ontstaat. ${ }^{200}$ Wil men hier spreken van een uniformering van de uitleg van het verdrag, ${ }^{201}$ dan dient er wel aan toegevoegd te worden dat het de uniformering van een minimum aan bescherming betreft. Het nationale recht kan op grond van artikel 53 EVRM een uitgebreider bescherming bieden, zij het niet onbeperkt, zoals hiervoor bij de bespreking van de positieve verplichtingen reeds aan de orde kwam.

$\mathrm{Nu}$ de interpretatie van het EHRM in de Nederlandse rechtsorde verbindende kracht heeft, is het gevolg dat ook de positieve verplichtingen verbindende kracht hebben en de rechter daaraan kan toetsen. Dat is opmerkelijk in zoverre dat sommige van deze positieve verplichtingen een tamelijk grote beleidsvrijheid laten en in dat opzicht enigszins kunnen lijken op verplichtingen voortvloeiende uit verdragsbepalingen waarin sociale grondrechten vastliggen. Laatstgenoemde bepalingen zijn meestal niet een ieder verbindend omdat zij normen bevatten die niet zonder meer als objectief recht kunnen functioneren.

Bij de doorwerking van de jurisprudentie van het EHRM in de Nederlandse rechtsorde hoeft overigens niet alleen of in de eerste plaats aan de mogelijkheid van toetsing van wettelijke voorschriften door de rechter te worden gedacht. Er zijn ook andere wijzen waarop het verdrag en de daarop gebaseerde jurisprudentie van het Hof invloed uitoefenen binnen de nationale rechtsorde. Wij maken daarom een aantal aanvullende opmerkingen. ${ }^{202}$

\section{Verdragsconforme uitleg}

In de eerste plaats zal de rechter ervoor kunnen kiezen een wettelijk voorschrift zo uit te leggen dat strijd met een ieder verbindende bepalingen vermeden wordt. ${ }^{203} \mathrm{De}$ Hoge Raad heeft in 1990 overwogen dat de rechter 'het Nederlandse recht zoveel mogelijk aldus dient uit te leggen en toe te passen dat de Staat aan zijn verdragsverplichtingen voldoet'. ${ }^{204}$ Door bijvoorbeeld strafbepalingen die de vrijheid van godsdienst en meningsuiting beperken restrictief uit te leggen kan mogelijke strijd worden vermeden. ${ }^{205}$

200. Gerards 2006, p. 99 e.v.

20I. Vergelijkbaar met het EG-recht, Martens 200ob, p. 757.

202. Een specifieke vorm van doorwerking betreft de vraag of een veroordeling van Nederland in Straatsburg onmiddellijk tot redres voor de betreffende klager in Nederland leidt. Er is hier sprake van een gebrekkige regeling, zie Barkhuysen \& Van Emmerik 2006, p. 39-64. Slechts in het Wetboek van strafvordering is een expliciete verwijzing naar een veroordeling in Straatsburg te vinden. Deze vormt reden om een herzieningsprocedure te starten. Overigens is het ook mogelijk dat justitie uit eigen beweging besluit tot bijvoorbeeld vervroegde invrijheidsstelling. In het bestuursrecht zal de klager in beginsel opnieuw een aanvraag in moeten dienen in de hoop dat de uitspraak door het EHRM als een novum wordt beschouwd. In het burgerlijk recht zal de klager zo nodig zijn toevlucht moeten zoeken tot een actie op grond van onrechtmatige rechtspraak.

203. Bijv. AGvB RvS 23 april I992, AB I992, 483, waarin de term 'geestelijk ambt' zodanig uitgelegd werd dat ook een humanistisch raadsman daaronder viel.

204. HR i6 november I990, NJ I992, I07.

205. Vgl. HR 9 januari 200I, NJ 200I, 203. Hierbij wordt overigens niet uitdrukkelijk naar artikel 9 of Io EVRM verwezen. Anders dan bij toetsing aan een verdragsbepaling hoeft dat ook niet. 
De Hoge Raad geeft in het algemeen aan verdragsconforme uitleg de voorkeur boven toetsing. ${ }^{206}$ Onder omstandigheden is de Hoge Raad ook bereid vrij ver te gaan in het 'conformeren' van de wet aan een verdrag. Zo bepaalde het Burgerlijk Wetboek dat de rechter het gezamenlijke gezag over een kind van ouders die niet met elkaar getrouwd zijn (geweest) en ook nooit het gezag over hun kind gezamenlijk hebben uitgeoefend, slechts op gezamenlijk verzoek van de ouders kon toewijzen. De Hoge Raad bepaalde echter dat de wet in overeenstemming met artikel 6 lid I EVRM moest worden uitgelegd en wel aldus dat ook een verzoek van alleen de vader tot toewijzing van het gezamenlijke gezag kan leiden. ${ }^{207}$

Dit voorbeeld mag niet verhullen dat er wel degelijk grenzen zijn aan een verdragsconforme uitleg. De mogelijkheid om in het nationaliteitsrecht 'vrouw' als 'man of vrouw' te lezen om mogelijke strijd met een verdragsrechtelijk verbod van discriminatie te voorkomen, was volgens AG Mok een stap te ver, ook al omdat deze 'interpretatie' tegen de bedoeling van de wetgever in zou gaan. De Hoge Raad overwoog in deze zaak overigens dat het aan de wetgever was om strijd met artikel 26 IVBPR op te heffen, nu er daarvoor meer oplossingen denkbaar waren. Het opheffen van die strijd viel met andere woorden buiten de rechtsvormende taak van de rechter. ${ }^{208}$

Een voordeel van de conforme uitleg is dat er geen onduidelijkheid ontstaat over de gelding van de verdragsconform uitgelegde bepaling. Het buiten toepassing laten, dat immers allerlei vragen kan oproepen over de mogelijkheid van toepassing in andere gevallen, leidt tot rechtsonzekerheid. ${ }^{209}$ Daar staat tegenover dat de conforme uitleg een wettelijke bepaling een betekenis kan geven die het begrip van de burger soms te boven gaat. Zo zal de burger moeten beseffen dat op zichzelf beledigende uitlatingen niet beledigend zijn in de zin van artikel $137 \mathrm{c} \mathrm{Sr}$, indien zij worden gedaan in de context van het maatschappelijke debat en niet onnodig grievend zijn. ${ }^{2 \text { IO }}$ In de lagere rechtspraak is bovendien geoordeeld dat het sanctioneren van (racistische) uitlatingen gedaan op een weinig bezochte, 'semi-openbare' website niet noodzakelijk is in een democratische samenleving, zodat dergelijke uitlatingen evenmin beledigend zijn in de zin van artikel $137 \mathrm{c} \mathrm{Sr}{ }^{21 I}$ Zo wordt het voor de burger - en het OM - wel heel moeilijk vast te stellen of een uitlating onder een strafbepaling valt.

Een variant van de verdragsconforme interpretatie is dat de rechter de verdragsbepalingen en de daarop gebaseerde jurisprudentie van het Hof soms zal kunnen verbinden met zijn eigen reeds bestaande jurisprudentie. De ontwikkeling van de jurisprudentie ten aanzien van de onrechtmatige perspublicatie mag een voorbeeld vormen. De Hoge Raad heeft in het verleden een aantal factoren onderscheiden die de rechter in zijn afweging moet betrekken. ${ }^{212}$ Daaraan is in latere jurisprudentie de eis toegevoegd dat een eventuele beperking van de persvrijheid noodzakelijk in een

206. Martens 1998 , p. 8 e.v.

207. HR 27 mei 2005, LJN AS7054.

208. HR I2 oktober I984, NJ I985, 230.

209. Zie al Alkema ig85, p. 33 .

210. Zie onder meer HR 9 januari 200I, NJ 200I, 203 en HR I5 april 2003, NJ 2003, 334 in onderlinge samenhang.

2II. Rb. Amsterdam 2 juni 2008, Mediaforum 2008-7/8, nr. 25.

2I2. HR 24 juni I983, NJ I984, 80I. 
democratische samenleving moet zijn. ${ }^{213}$ Deze voorwaarde is centraal komen te staan terwijl de van oudsher aangewezen factoren relevant zijn gebleven bij de afweging die als onderdeel van de noodzakelijkstoets is te beschouwen. ${ }^{214}$

Een volgende opmerking is dat niet alleen de rechter maar ook de wetgever in voorkomende gevallen heeft gereageerd op uitspraken van het EHRM en de wet in overeenstemming heeft gebracht met de eisen gesteld aan de verdragsbepalingen. Indien uit arresten van het EHRM blijkt dat de Nederlandse wetgeving niet strookt met het EVRM, dan vloeit daar immers indirect de verplichting voor de wetgever uit voort om daaraan een eind te maken. ${ }^{215}$ Is dat gebeurd, dan zal de rechter vervolgens eenvoudigweg de wet kunnen toepassen.

Ook het bestuur is overigens aan de verdragsbepalingen met de daarin geïncorporeerde interpretatie van het EHRM is gebonden. Het bestuur zal een wettelijke bevoegdheid dan ook niet daarmee in strijd mogen uitoefenen. Nu het EHRM bijvoorbeeld heeft geoordeeld dat een betoging, die alleen op korte termijn georganiseerd kon worden, niet alleen daarom mag worden verboden omdat zij niet (tijdig) is aangemeld, ${ }^{216}$ mag een Nederlandse burgemeester zich niet meer simpelweg laten leiden door de Wet openbare manifestaties die hem de bevoegdheid geeft dat wél te doen. ${ }^{217}$

Verdergaande bescherming - op grond van het EVRM?

Artikel 53 EVRM bepaalt uitdrukkelijk dat het EVRM geen afbreuk doet aan de grondrechtelijke bescherming geboden door andere verdragen en nationale wetgeving. Het EVRM staat de nationale rechter dus toe op grond van het nationale recht meer bescherming te bieden dan de bepalingen van het EVRM en de daarop gebaseerde jurisprudentie van het EHRM voorschrijven. Uiteraard zal deze extra bescherming verenigbaar moeten zijn met de andere bepalingen van het verdrag. In dit verband zij herhaald dat positieve verplichtingen ertoe kunnen nopen een bepaald recht niet een al te grote bescherming te geven.

De meer specifieke vraag of de Nederlandse rechter meer bescherming op grond van het EVRM mag bieden dan waartoe de jurisprudentie van het EHRM verplicht, is daarmee niet beantwoord. Deze vraag dringt zich in het bijzonder op indien het EHRM de nationale autoriteiten een relatief ruime appreciatiemarge laat, omdat zij in casu beter in staat worden geacht de bepalingen uit te leggen of een inschatting te maken van het gewicht van bepaalde belangen.

Omdat het EHRM niet toeziet op een uniforme uitleg van de verdragsbepalingen, maar controleert of er minimaal een bepaald niveau van bescherming wordt gegeven, zou het vreemd zijn indien het verdrag er zich tegen zou verzetten dat de nationale rechter op grond van het verdrag het verdragsrechtelijke minimum te boven gaat. ${ }^{218}$

2I3. HR 6 januari I995, NJ I995, 422.

2I4. Schuijt 2008, p. I02-I08.

2I5. Zie het nog te verschijnen preadvies van J-P. Loof voor de Staatsrechtconferentie 2007, p. 9.

2I6. EHRM I7 juli 2007, Bukta a.o. v. Hungary; anders in dezen HR I7 november 2006, AB 2007, 23.

217. Zie Loof 2007 , p. 475.

2I8. Barkhuysen 2004, p. 47. 
Het bieden van een dergelijke verdergaande bescherming op grond van het EVRM is voor de Nederlandse rechter ook verleidelijk, zeker omdat zijn mogelijkheden om op grond van de Grondwet bescherming te bieden als gevolg van het toetsingsverbod beperkt zijn. ${ }^{219}$ Een bijkomend voordeel van een ruimere bescherming is uiteraard, dat de kans dat een eventuele procedure in Straatsburg voor Nederland negatief uitvalt, kleiner wordt. Indien immers hooguit die bescherming mag worden gegeven die op grond van de jurisprudentie van het EHRM dwingend is voorgeschreven, opereert de Nederlandse rechter steeds op de grens van wat uitdrukkelijk is geboden.

Daar staat het idee tegenover dat de interpretatie van het EHRM is geïncorporeerd in de een ieder verbindende bepaling waar de nationale rechter aan mag toetsen. Strikt geredeneerd komt dan aan die interpretatie verbindende kracht toe en niet aan een daarvan afwijkende interpretatie door de Nederlandse rechter, zodat de rechter de bevoegdheid zou missen om nationale wettelijke voorschriften te toetsen aan een afwijkend uitgelegde verdragsbepaling.

De doctrine van de Hoge Raad lijkt aan te sluiten bij het laatstgenoemde uitgangspunt, zo blijkt uit een arrest van ro augustus 200I. In casu lag de vraag voor of de Nederlandse rechter een lesbische relatie onder de reikwijdte van 'family life' in de zin van artikel 8 EVRM zou kunnen brengen, ondanks het feit dat de rechtspraak van het Hof en de rapporten van de Commissie duidelijk in een andere richting wezen. ${ }^{220}$ Deze verdergaande uitleg zou ertoe hebben geleid dat bepaalde wettelijke voorschriften onverenigbaar zouden zijn met artikel 8 EVRM en op grond van artikel 94 buiten toepassing zouden moeten worden gelaten. De Hoge Raad nu stelt dat:

'Een zodanige onverenigbaarheid kan niet worden aangenomen uitsluitend op basis van een uitleg door de nationale - Nederlandse - rechter van het begrip "family life" in het licht van recent tot stand gekomen wetgeving, die leidt tot een verdergaande bescherming dan op grond van de rechtspraak van het EHRM met betrekking tot art. 8 EVRM mag worden aangenomen.'

De overweging van de HR komt erop neer dat de Nederlandse rechter pas een wettelijk voorschrift buiten toepassing zal mogen laten wegens strijd met een bepaling van het EVRM indien de bepaling - als geïnterpreteerd door het EHRM - dat min of meer dwingend voorschrijft. Wil de wetgever een verdergaande bescherming bieden dan staat hem dat uiteraard vrij, althans zolang deze verdergaande bescherming niet in strijd komt met de (positieve) verplichtingen op grond van het EVRM.

De notie, dat de nationale rechter niet méér bescherming moet willen bieden dan het EHRM, komt eveneens naar voren uit een arrest van de Hoge Raad uit I989. ${ }^{22 \mathrm{I}}$ Daarin paste de Hoge Raad een door hemzelf gegeven ruime uitleg van het begrip

219. Zie al Alkema 1985 , p. 33.

220. HR Io augustus 200I, NJ 2002, 278.

22I. HR Io november I989, NJ I990, 628; vgl. ook HR I9 oktober I990, NJ I992, I29, waarin de Hoge Raad de reikwijdte van artikel I2 EVRM niet uitstrekt over personen van gelijk geslacht, verwijzend naar EHRM I7 oktober I986, Rees v. United Kingdom. In andere gevallen heeft de Hoge Raad zich in het verleden wel 'dynamischer' opgesteld dan waartoe de jurisprudentie van het EHRM dwingt, zie bijv. HR I5 september I989, NJ I990, 332. 
'gezinsleven' aan, naar aanleiding van het Berrehab-arrest van het EHRM. De toenmalige ruime uitleg van de Hoge Raad was geïnspireerd door het Marckx-arrest van het EHRM en hield in dat er tussen een kind en de biologische vader per definitie sprake was van 'family life' in de zin van artikel 8 EVRM. Deze uitleg hanteerde de

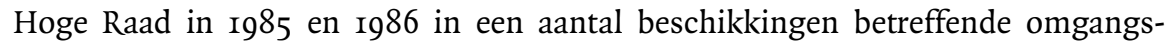
regelingen. ${ }^{222}$ Het Berrehab-arrest was, als gezegd, voor de Hoge Raad reden zijn interpretatie aan te passen. Biologisch vaderschap was op zichzelf niet meer per se voldoende om van 'family life' te spreken.

De overeenkomst met het eerder behandelde arrest is uiteraard dat de Nederlandse rechter niet geneigd is een ruimere uitleg aan een verdragsbepaling te geven dan het EHRM doet. Het verschil is dat de verdergaande interpretatie niet zonder meer tot het buiten toepassing laten van een wettelijk voorschrift zou hebben hoeven te leiden. Daar staat tegenover dat de verdergaande bescherming van het recht op gezinsleven van de man tot een beperking van de bescherming van het recht op gezinsleven van de vrouw op grond van artikel 8 EVRM zou hebben geleid. ${ }^{223}$ In dat geval is voorzichtigheid geboden om niet het verdragsrecht van de vrouw te schenden. ${ }^{224}$

Met name het arrest van Io augustus 200I noopt tot enkele opmerkingen. De terughoudende opstelling van de rechter lijkt niet volledig verklaard te kunnen worden uit de verhouding tussen rechter en wetgever en uit de bijzondere positie van de wet in formele zin in de Nederlandse rechtsorde. De Hoge Raad spreekt immers over 'wettelijke voorschriften', waaronder ook lagere regelingen vallen. ${ }^{225}$ Hoewel de traditionele constitutionele verhouding tussen wetgever en rechter meespeelt, lijkt de meer specifieke verklaring ons inziens dat de verdragsbepaling - in de door het EVRM geïnterpreteerde vorm - verbindende kracht heeft en de Nederlandse rechter niet op grond van een afwijkende interpretatie wettelijke voorschriften buiten toepassing mag laten. De doctrine lijkt is dus mede gebaseerd op de uitleg van artikel 93 en 94 Grondwet. ${ }^{226}$

De Nederlandse rechter zal, indien in de jurisprudentie van het EHRM een onmiddellijk toepasbaar precedent ontbreekt, moeten inschatten hoe het EHRM zou hebben geoordeeld. ${ }^{27}$ Zijn interpretatie zal zoveel mogelijk dienen aan te sluiten bij de bestaande jurisprudentie van het EHRM. Daarbij lijkt het niet geheel uitgesloten dat hij bepaalde ontwikkelingen in die jurisprudentie combineert en zo anticipeert op een stap die het EHRM waarschijnlijk zal gaan maken. Anders zou hij bewust het risico moeten nemen dat een eventuele procedure in Straatsburg tot een veroordeling van Nederland leidt. De Nederlandse rechter mag met andere woorden niet voor

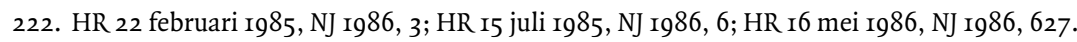

223. Zie ook noot dB onder HR io november I989, NJ I990, 628.

224. Vgl. Doorduijn I994, p. I45.

225. De A-G wees wel expliciet op artikel I20 Grondwet.

226. De Nederlandse rechter zou zo geredeneerd aan bepalingen van mensenrechtenverdragen, waarbij niet een internationale rechter in het leven is geroepen die een bindende uitleg van de verdragsbepalingen geeft, opmerkelijk genoeg wel die meerwaarde kunnen geven.

227. Vgl. Martens 200ob, p. 76o: 'ten minste te oordelen zoals naar zijn mening het EHRM zou hebben geoordeeld'. In dat 'ten minste' ligt naar onze mening de wens besloten meer ruimte te creëren voor de eerder genoemde opvatting dat de Nederlandse rechter het Europese minimumniveau te boven mag gaan. 
de muziek uit lopen, maar hij mag onder omstandigheden wél zelf vaststellen waar de muziek zich ongeveer moet bevinden.

De door de Hoge Raad geformuleerde verplichting tot terughoudendheid zorgt ervoor dat de marge, die het EHRM aan de nationale autoriteiten laat, door de Nederlandse rechter per omgaande wordt 'doorgegeven' aan de wetgever. Dat betekent dat de Europese 'minimumnorm' voor de Nederlandse rechter tegelijkertijd de 'maximumnorm' is. Nu óók de wetgever zich soms vooral lijkt af te vragen of hij voldoet aan de minimumnorm, zal de bescherming op nationaal niveau dicht bij het Europese minimum kunnen komen te liggen. Het risico dat er zich in concrete gevallen schendingen voordoen, zal dan op de koop toe moeten worden genomen. Een verdergaande rechterlijke bescherming lijkt op dit punt alleen gevonden te kunnen worden in een uitbreiding van de grondrechtelijke bescherming van nationale origine, meer in het bijzonder in de opheffing van het toetsingsverbod. Een voorstel tot gedeeltelijke opheffing van dit verbod is in paragraaf 2.I reeds kort aan de orde geweest.

Tot zover hebben we ons voornamelijk beziggehouden met de uitleg van de reikwijdte van een verdragsbepaling. Het is daarom de vraag of de overwegingen van de Hoge Raad in dezelfde mate zien op het toepassen van de noodzakelijkheidstoets of meer in het algemeen op het afwegen van belangen. Daarbij gaat het immers niet alleen om de uitleg van een rechtsbegrip, maar ook om de vaststelling, waardering en afweging van relevante belangen in het concrete geval. Er zijn daarbij vaak zoveel factoren in het geding dat uit de jurisprudentie van het EHRM nooit simpelweg de juiste afweging is af te leiden. Dat lijkt de nationale rechter op bepaalde punten wat meer ruimte te kunnen geven.

De door de Hoge Raad geformuleerde beperkingen voor de rechter doen zich nog minder sterk gevoelen wanneer de rechter wetgeving verdragsconform interpreteert. In dat geval gaat het immers niet om het op grond van artikel 94 Grondwet buiten toepassing laten van wettelijke voorschriften en staan de overwegingen van de Hoge Raad er in principe niet aan in de weg dat de rechter een grotere bescherming biedt dan het EHRM zou bieden. Is echter de belangrijkste bedoeling van verdragsconforme interpretatie het voorkomen van strijd met de verdragsbepaling, waarin de uitleg van het EHRM is geïncorporeerd, dan zal ook deze interpretatie niet verder hoeven te gaan dan de jurisprudentie van het Hof voorschrijft. Het ligt bovendien niet zonder meer voor de hand dat de rechter twee interpretaties van een verdragsbepaling hanteert: één in het kader van artikel 94 Grondwet en één voor gebruik buiten dat kader.

Daar staat tegenover dat het EVRM veelal één van de factoren is die de interpretatie mede bepalen, zodat een samenspel van EVRM en andere factoren, bijvoorbeeld de bedoeling van de wetgever dat het strafrecht een ultimum remedium is, wel degelijk tot een interpretatie kunnen leiden die verder gaat dan alleen uit de jurisprudentie van het EHRM zou afgeleid kunnen worden.

Bij de beoordeling van handelingen van bestuursorganen doen de overwegingen van de Hoge Raad zich evenmin in dezelfde mate gelden. Het vernietigen van een besluit is immers te onderscheiden van het buiten toepassing laten van een wettelijk voorschrift. Daarbij valt overigens op te merken dat bepaalde factoren die de omvang van 
de appreciatiemarge beïnvloeden ook van belang in de verhouding tussen de nationale rechter en bestuursorganen. ${ }^{228}$ Als voorbeeld mag de beoordeling van besluiten ter handhaving van de openbare orde dienen. ${ }^{229}$

In andere gevallen zal de rechter beslissingen van bestuursorganen juist wel strikt aan de verdragsbepalingen moeten toetsen, bijvoorbeeld indien de meest wezenlijke rechten als vastgelegd in artikel 2 en 3 EVRM in het geding zijn. ${ }^{23^{\circ}} \mathrm{Nu}$ laat het EHRM de nationale autoriteiten hier weinig of geen appreciatiemarge, zodat de nationaalrechtelijke vraag aan welk orgaan een eventuele marge toekomt zich niet voordoet. Het is dan ook enigszins wrang dat de Nederlandse rechter in bepaalde vreemdelingenzaken die zien op de inschatting van het risico dat een asielzoeker na uitzetting onderworpen wordt aan foltering of een vernederende of onmenselijke behandeling of bestraffing het bestuur een beoordelingsvrijheid laat die groter is dan de marge die het EHRM aan de nationale autoriteiten laat. ${ }^{23}$

\section{Grenzen rechtsvormende taak}

Constateert de rechter dat een wettelijk voorschrift in strijd is met een een ieder verbindende bepaling uit het EVRM, dan zal hij op grond van artikel 94 Grondwet het wettelijk voorschrift buiten toepassing moeten laten. In veel gevallen zal dat de rechthebbende effectieve rechtsbescherming kunnen bieden. Men denke aan een strafbepaling die buiten toepassing wordt gelaten zodat de verdachte wordt ontslagen van rechtsvervolging of aan de vernietiging van het besluit een vergunning te weigeren nu de regeling op grond waarvan dat gebeurde buiten toepassing had moeten worden gelaten.

In andere gevallen zal alléén het buiten toepassing laten de rechthebbende onvoldoende baten. Dat zal bijvoorbeeld het geval zijn wanneer vastgesteld wordt dat de begunstigende regeling, waarvoor de rechthebbende niet in aanmerking kwam, strijdig is met het gelijkheidsbeginsel. ${ }^{232}$ Het buiten toepassing laten van de regeling leidt er in dat geval nog steeds niet toe dat de rechthebbende in aanmerking komt voor de begunstigende maatregel. ${ }^{233}$ In zulke gevallen rijst de vraag naar de

228. Rombouts 2003. De appreciatiemarge is tot op zekere hoogte te vergelijken met de marge die een nationale rechter onder omstandigheden aan het bestuur laat. Vgl. ook Van der Pot 2006, p. 277.

229. ABRvS I4 mei I996, JB I996, I69; EHRM 4 juni 2002, Olivieira v. The Netherlands.

230. Vgl. ook 'Terugblik op Straatsburg, Interview met W.M.E Thomassen, voormalig Nederlandse rechter in het EHRM', NJCM-bulletin (55 jaar EVRM) 2006, p. 23.

23I. EHRM 5 juli 2005, Saïd v. The Netherlands. Recenter EHRM II januari 2007, Salah Sheekh v. The Netherlands. In het laatste geval overweegt het EHRM dat de benadering van de ABRvS eigenlijk bij voorbaat uitsluit dat er in dit geval een inschatting wordt gemaakt, die recht doet aan het belang van artikel 3 EVRM.

232. De inwerkingtreding van artikel I, Twaalfde Protocol, waarin anders dan in artikel I4 EVRM een zelfstandig verbod van discriminatie is vastgelegd, zal de 'vraag naar rechtsvorming' door de rechter mogelijkerwijs doen groeien.

233. De vorm van de regeling lijkt dus te kunnen bepalen of buiten toepassing laten een oplossing biedt. Bepaalt een artikel in het eerste lid dat alle burgers voor een begunstiging in aanmerking komen en zondert het tweede lid - ten onrechte - bepaalde groepen uit dan zorgt het buiten toepassing laten van lid twee voor een oplossing. Is de regel dat alleen bepaalde met name genoemde groepen in aanmerking komen dan biedt het buiten toepassing laten van die regel geen soelaas. 
- grenzen van de - rechtsvormende taak van de rechter. ${ }^{234}$ De grenzen van de rechtsvormende taak kunnen voorts in zicht komen indien er sprake is van een positieve verplichting, waaraan niet voldaan wordt of kan worden op grond van de bestaande wetgeving. ${ }^{235}$

Rechtsvorming is de Nederlandse rechter niet vreemd. Hij interpreteert vage normen, maar vormt ook het recht en de grens daartussen is bovendien vloeiend. De uitbreiding van de grondslagen voor de onrechtmatige daad (Lindenbaum/Cohen), de hele verspreidingsjurisprudentie (Tilburg en verder) en de regels ten aanzien van stakingen en euthanasie zijn scheppingen van de rechter. Wij concentreren ons hier in het bijzonder op de - grenzen gesteld aan de - rechtsvormende taak indien een rechtstekort niet kan worden opgeheven louter door het buiten toepassing laten van een wettelijk voorschrift wegens strijd met een verdragsbepaling. De doctrine is op dit punt in belangrijke mate door de Hoge Raad zelf uiteengezet. Daarom citeren wij hier in extenso uit het zogenaamde Arbeidskostenforfait-arrest uit I999:

'3.I4 In dit geval kan een dergelijke bescherming niet daarin worden gevonden dat de discriminatoire regeling (...) buiten toepassing wordt gelaten. Die oplossing zou immers belanghebbende niet baten. Dat doet de vraag rijzen of de rechter de effectieve rechtsbescherming kan bieden door op andere wijze in het door de regeling veroorzaakte rechtstekort te voorzien dan wel of hij zulks vooralsnog aan de wetgever dient over te laten. In zodanige situaties dienen, met inachtneming van de aard van het rechtsgebied waar de vraag rijst, twee belangen tegen elkaar afgewogen te worden. Voor het zelf in het rechtstekort voorzien pleit dat de rechter daardoor aan de belanghebbende direct een effectieve rechtsbescherming kan bieden, maar ertegen pleit dat in de gegeven staatsrechtelijke verhoudingen de rechter bij zulk ingrijpen in een wettelijke regeling een terughoudende opstelling past.

3.15 Deze afweging zal in het algemeen ertoe leiden dat de rechter aanstonds zelf in het rechtstekort voorziet indien zich uit het stelsel van de wet, de daarin geregelde gevallen en de daaraan ten grondslag liggende beginselen, of de wetsgeschiedenis, voldoende duidelijk laat afleiden hoe zulks dient te geschieden. In gevallen echter waarin verschillende oplossingen denkbaar zijn en de keuze daaruit mede afhankelijk is van algemene overwegingen van overheidsbeleid of belangrijke keuzes van rechtspolitieke aard moe-

234. Het komt overigens ook voor dat buiten toepassing laten mogelijkerwijs wel rechtsbescherming zou kunnen bieden, maar dat de rechter zich toch terughoudend opstelt en het aan de (Grond)wetgever wil overlaten om vast te stellen in welke gevallen strijdigheid bestaat. Zie bijv. ABRvS 29 oktober 2003, AB 2003, 463. De ABRvS overwoog dat het zonder meer uitsluiten van onder curatele gestelden van het kiesrecht in concrete gevallen in strijd zou kunnen zijn met artikel 25 IVBPR. Desondanks wilde de Afdeling het aan de wetgever overlaten te bepalen in welke gevallen dat daadwerkelijk zo zou zijn en om daarvoor een oplossing te bieden. Hier kan men zich met annotator Stolk afvragen waarom in dit specifieke geval niet gewoon is getoetst en de bepalingen buiten toepassing zijn gelaten. Daarmee zou namelijk effectieve rechtsbescherming zijn geboden. Sterker nog: de rechter was dat naar onze mening op grond van 93 en 94 Grondwet verplicht. Nu betrof het hier het betrekkelijk unieke geval van strijd tussen verdragsbepaling en Grondwet. Deze kwestie komt daarom nog terug in paragraaf 5. Inmiddels is de grondwettelijke uitsluiting van curandi van het kiesrecht overigens opgeheven. Zie de Wet van 27 juni 2008, Stb. 2008, 272.

235. De uit het gelijkheidsbeginsel voortvloeiende verplichting tot 'gelijke begunstiging' is overigens vergelijkbaar met een positieve verplichting. 
ten worden gemaakt, is aangewezen dat de rechter die keuze vooralsnog aan de wetgever laat, zulks zowel in verband met de in 3.14 bedoelde staatsrechtelijk gewenste terughoudendheid van de rechter als wegens zijn beperkte mogelijkheden op dit gebied. Niet uitgesloten is echter dat de afweging anders moet uitvallen ingeval de wetgever ermee bekend is dat een bepaalde wettelijke regeling tot een ongerechtvaardigde ongelijke behandeling in de zin van voormelde verdragsbepalingen leidt, maar nalaat zelf een regeling te treffen die de discriminatie opheft. ${ }^{236}$

In casu zag de rechter meer mogelijke oplossingen om de ongelijke behandeling op te heffen, zodat rechtsvorming door de rechter - vooralsnog - niet voor de hand lag. Hij abstineerde, maar stelde wel expliciet dat hij ervan uitging dat de regering met de nodige spoed een wetsvoorstel zou indienen om aan de ongelijke behandeling een einde te maken. Daarbij wees hij nogmaals op de mogelijkheid dat zijn afweging in de toekomst anders uit zou kunnen vallen, namelijk in geval de wetgever talmt.

Een bekend voorbeeld van een geval waarin de rechter wél in het rechtstekort voorzag betrof de regeling van de ouderlijke macht (tegenwoordig: het ouderlijke gezag). Deze regeling kende niet de mogelijkheid dat ongehuwde ouders gezamenlijk de ouderlijke macht uitoefenden. De rechter oordeelde dat de regeling op dat punt in strijd was met artikel 8 jo. I4 EVRM. Nu het stelsel van de wet en de bedoeling van de wetgever volgens de Hoge Raad beide in één bepaalde richting wezen om in het rechtstekort te voorzien, kon de rechter zelf effectieve rechtsbescherming bieden. ${ }^{237}$

De door de Hoge Raad geformuleerde doctrine noopt tot een aantal opmerkingen. Een eerste opmerking is dat de Hoge Raad niet expliciet de reden voor de terughoudendheid van de rechter geeft. Hij verwijst slechts naar 'de gegeven staatsrechtelijke verhoudingen'. Het ligt in eerste instantie voor de hand te denken aan het feit dat regelgeving het primaat is van de democratisch gelegitimeerde wetgever. Een dergelijk primaat hoeft op zichzelf echter nog niet te betekenen dat de rechter niet in voorkomende gevallen op rechtsstatelijke gronden zelf rechtsbescherming zou mogen bieden. De voormalige president van de Hoge Raad, Martens, heeft in zijn afscheidsrede geopperd dat de terughoudendheid van de rechter in verband gebracht moet worden met de in Nederland bestaande verhoudingen tussen de wetgevende en de rechtsprekende macht, zoals deze door ons in paragraaf 2.I is geschetst. ${ }^{238}$ Deze verhoudingen lijken dus ook hier 'door te werken', ook al kan men de vraag stellen of dat terecht is, nu artikel 93 en 94 Grondwet relatief nieuwe bepalingen zijn die het naleven van verdragsverplichtingen vooropstellen. ${ }^{239}$

De doctrine van de Hoge Raad ontzegt de rechter niet de bevoegdheid om zelf in enig rechtstekort te voorzien. Dat blijkt in casu overduidelijk uit de overweging dat de rechter op termijn mogelijkerwijs wel zelf in het rechtstekort zal voorzien. De terughoudende opstelling is het gevolg van beleidsmatige overwegingen en van de

236. HR I2 mei i999, NJ I999, I70.

237. HR 2I maart I986, NJ I986, 585. Het ging daarbij niet om recente wetgeving maar meer om het moderniseren van verouderde wetgeving, vgl. De Lange I999, p. Io.

238. Martens 2000a, p. 75 I.

239. Alkema 2005. 
uitkomst van een belangenafweging. ${ }^{240}$ Dat leidt tot de vraag of de rechter altijd de bevoegdheid heeft om zelf in een rechtstekort te voorzien. Dat is ons inziens niet altijd het geval. Er zijn ook situaties denkbaar waarin de grenzen aan de rechtsvormende taak een meer absoluut karakter hebben. Stel dat uit de jurisprudentie van het EHRM blijkt dat de staat een positieve verplichting heeft om bepaalde milieudelicten strafbaar te stellen en stel dat de Nederlandse strafwetgeving op dat punt een lacune vertoont, dan kan de rechter gezien ook artikel 7 lid I EVRM - men vergelijke ook artikel 16 Grondwet - daar in het algemeen niet zelf in voorzien, ook al zou de wetgever talmen.

In dit verband kan ook gewezen worden op de zaak X en Y tegen Nederland. ${ }^{24 \mathrm{I}}$ In de procedure voor de nationale rechter, die voorafging aan de klacht in Straatsburg, had het Hof Arnhem besloten tot afwijzing van de klacht tot niet-vervolging omdat een uitbreidende interpretatie, die de onbedoelde lacune in de strafvorderlijke regeling zou dichten en daarmee - ook in dit specifieke geval - vervolging mogelijk zou maken, de belangen van de verdachte zou schaden. ${ }^{242} \mathrm{Nu}$ kan men erover van mening verschillen of het in casu bieden van effectieve rechtsbescherming door de rechter in strijd zou zijn gekomen met het nulla poena-beginsel, ${ }^{243}$ maar het is wel duidelijk dat we hier aan een meer absolute grens aan de rechtsvormende taak van de rechter raken.

Meer in het algemeen kan het een probleem zijn dat het zelf voorzien in een rechtstekort gepaard gaat met een inmenging in een grondrecht van een derde. Het EVRM kent veelal het vereiste dat die inmenging 'bij de wet voorzien is'. In geval de betreffende positieve verplichting alleen uit de jurisprudentie van het EHRM naar voren komt en geen basis heeft in het nationale recht, zal aan dat vereiste alleen voldaan kunnen zijn, omdat de jurisprudentie van het EHRM direct doorwerkt in de Nederlandse rechtsorde. In een volgende paragraaf besteden we aandacht aan de verhouding tussen positieve verdragsverplichtingen en het grondwettelijke vereiste van een formeel-wettelijke grondslag voor een beperking van een grondrecht.

Een ieder verbindendheid en grenzen rechtsvormende taak

De vraag of de rechter in een rechtstekort kan voorzien moet overigens uitdrukkelijk onderscheiden worden van de vraag of een verdragsbepaling een ieder verbindend is. In de literatuur is in het verleden wel betoogd dat de rechter ingeval hij de rechthebbende geen rechtsbescherming kan bieden, hij dat niet doet of hoeft te doen omdat hij de verdragsbepaling in casu niet een ieder verbindend acht. ${ }^{244}$ Deze opvatting zou erop neerkomen dat de een ieder verbindendheid afhangt van de casus

240. Martens 2000, p. $75 \mathrm{I}$.

24I. EHRM 27 februari 1985 , X \& Y v. The Netherlands.

242. Hof Arnhem I2 juli I979, NJ I980, I75.

243. Meijers stelt in zijn noot onder EHRM 27 februari $1_{985}$, X \& Y v. The Netherlands, NJCM-bulletin 2000 , p. 289, dat in het rechtstekort voorzien niet in strijd was met het nulla poena-beginsel nu de beperkende regeling in de wet niet bedoelde de verdachte te beschermen. Alkema in zijn noot onder NJ 1985, 525, sluit juist niet uit dat het nulla poena-beginsel in het geding zou kunnen zijn. Zie hierover uitgebreider Rozemond I999, p. II7 e.v.

244. Vgl. Hartkamp 2000, p. 32. 
waarop de bepaling moet worden toegepast. Dat komt niet als juist voor, gezien de eerder geschetste heersende leer dat een verdragsbepaling óf een ieder verbindend is óf niet. ${ }^{245}$

Dat wil niet zeggen dat er niet enige parallellen te trekken zijn tussen de beoordeling van het karakter van een verdragsbepaling en de redenen voor de rechter om - vooralsnog - niet in het rechtstekort te voorzien. ${ }^{246}$ Indien een verdragsbepaling namelijk zelf in het bijzonder om regelgeving vraagt, zal deze minder snel een ieder verbindend zijn, zeker wanneer hetgeen geregeld dient te worden groot van omvang is en er allerlei beleidskeuzen gemaakt dienen te worden. Het is tot op zekere hoogte vergelijkbaar dat de rechter zich terughoudend zal opstellen indien de regeling die nodig is om in een rechtstekort te voorzien complex van aard is. De analogie ziet ook op de eventuele financiële consequenties. Deze kunnen voor de rechter een overweging vormen om een bepaling het een ieder verbindende karakter te ontzeggen. Zij kunnen ook voor de rechter een overweging vormen om niet zelf in een rechtstekort te voorzien. Voor de positieve verplichtingen op grond van het EVRM geldt echter dat zij deel uitmaken van de een ieder verbindende bepalingen. Eventuele problemen ten aanzien van de draagwijdte en complexiteit doen daar niet aan af, maar zullen de rechter wel tot de grenzen van zijn rechtsvormende taak kunnen voeren.

De rechter heeft in voorkomende gevallen de vraag, of een bepaling een ieder verbindend is, ook wel overgeslagen om direct vast te stellen dat - ook als dat zo zou zijn - hij toch niet zelf in het rechtstekort zou kunnen voorzien. ${ }^{247}$ Een variant van een dergelijke aanpak is dat de rechter er wél vanuit gaat dat een verdragsbepaling een ieder verbindend is maar niet vaststelt of er strijd is met een wettelijk voorschrift, omdat het vervolgens bieden van een oplossing voor het rechtstekort de rechtsvormende taak van de rechter te buiten zou gaan. ${ }^{248}$

Deze oordelen kunnen soms de proceseconomie dienen, de gang van zaken is toch onbevredigend. Het is om twee redenen van belang dat de rechter zich uitspreekt over de verenigbaarheid van het wettelijk voorschrift met de - als een ieder verbindend beoordeelde - verdragsbepaling, ook als hij meent zelf geen effectieve rechtsbescherming te moeten bieden. In de eerste plaats is het voor de wetgever van belang om te weten of er een rechtstekort is, waarin voorzien moet worden. Zelfs als de wetgever zich na een dergelijk signaal van de rechter niet geroepen acht om regelgeving aan te passen, kan het nuttig zijn wanneer de wetgever op zijn beurt laat weten waarom hij daar de voorkeur aan geeft. ${ }^{249}$ De doctrine van de Hoge Raad inzake rechterlijke rechtsvorming komt immers gedeeltelijk neer op een (beperkte)

245. Zie ook Fleuren 2004, p. 362-363.

246. Vgl. Van der Pot 2006, p. 829.

247. Van der Pot 2006 , p. 826-827. Wat ook voorkomt, is dat de rechter in het midden laat of de casus binnen de reikwijdte van een een ieder verbindende bepaling valt, nu bij een bevestigend antwoord een rechtstekort zou ontstaan en het bieden van een oplossing de rechtsvormende taak van de rechter te buiten zou gaan, bijv. HR I9 januari I990, NJ I99I, 2I3.

248. HR I2 oktober I984, NJ I985, 230 (in casu was de wetgever overigens al bezig met een non-discriminatoire regeling). Zie ook ABRvS 29 okt 2003, JB 2004, 3. Vgl ook HR 5 september I997, NJ I998, 686, waarin de Hoge Raad overweegt dat, als adoptie al onder de reikwijdte van artikel 8 zou vallen, voor het voorzien in het rechtstekort vergaande rechtspolitieke keuzes nodig zouden zijn.

249. Vgl. de president van de Hoge Raad, Davids, in zijn rede bij de opening van het academisch jaar 2006-2007 van de Academie voor wetgeving. 
dialoog tussen rechter en wetgever. ${ }^{250}$ Dat komt het duidelijkst naar voren indien de rechter de wetgever aangewezen acht om in het rechtstekort te voorzien, zodat hij zelf - voorlopig - abstineert. In het verlengde van het eerder aangehaalde Arbeidskostenforfait-arrest is de wetgever inderdaad met een aangepaste regeling gekomen. Deze is ook zelf weer bij de rechter aangevochten, maar de rechter achtte de nieuwe regeling niet in strijd met het gelijkheidsbeginsel. ${ }^{251}$

In de tweede plaats is het oordeel dat het wettelijk voorschrift in strijd is met een een ieder verbindende bepaling en buiten toepassing gelaten dient te worden van belang voor de rechthebbende, ook als de rechter vervolgens niet zelf in het rechtstekort voorziet. Het oordeel van de rechter kan de rechthebbende enige genoegdoening opleveren. ${ }^{252}$

EHRM en grenzen rechtsvormende taak nationale rechter

In het voorafgaande is geconstateerd dat een belangenafweging de rechter er vanaf kan doen zien om zelf in het rechtstekort te voorzien. Het is daarbij de vraag of de doctrine van de Hoge Raad het belang van de individuele rechtsbescherming wel voldoende in acht neemt. ${ }^{253}$ Mede gelet op artikel I3 EVRM moet de rechthebbende immers effectieve rechtsbescherming worden geboden, ${ }^{254}$ en bij de uitleg van het EVRM hoeft het EHRM geen rekening te houden met het specifieke belang dat is gemoeid met de instandhouding van de verhouding tussen rechter en wetgever in Nederland.

Een aantal zaken waarin de Nederlandse rechter abstineerde, is gevolgd door een procedure bij het EHRM. ${ }^{255}$ Daarbij viel het oordeel van het EHRM niet steeds positief uit. ${ }^{256}$ De zaak Kroon zag op de onmogelijkheid voor de moeder van een kind om het vaderschap van haar (ex-)man te ontkennen. Dat was volgens de Hoge Raad in strijd met artikel 8 jo. I4 EVRM, maar de rechter achtte de wetgever de aangewezen instantie om in het rechtstekort te voorzien. ${ }^{257} \mathrm{Om}$ die reden bood hij niet zelf effectieve rechtsbescherming. In de daaropvolgende procedure in Straatsburg oordeelde het EHRM dat Nederland artikel 8 EVRM - los van artikel I4 EVRM - had geschonden.

Deze zaak kreeg nog een vervolg nu 8 dagen na de uitspraak van het EHRM de Hoge Raad in een andere zaak wederom de vraag diende te beantwoorden of de rechter zelf in voornoemd rechtstekort kan voorzien. De Hoge Raad bleef bij zijn standpunt dat de wetgever de aangewezen instantie is. ${ }^{258}$ Daaruit zou men eventueel kunnen opmaken dat het oordeel van het EHRM niet beslissend is bij het beantwoor-

\footnotetext{
250. Zie meer in het algemeen het nog te verschijnen preadvies van Gerards voor de staatsrechtconferentie 2007, zie ook van Van Kreveld 2006, p. I86-r96.

25I. HR I4 juni 2002, BNB 2002, 289.

252. Op de mogelijkheid van schadevergoeding gaan wij hier niet apart in.

253. Vgl. Martens 2000a, p. 752-753.

254. Vgl. Barkhuysen 2004, p. 98; vgl ook Barkhuysen e.a. 2000, p. 389 i.v.m. HR 5 sept I997, NJ I998, 686.

255. Het EHRM heeft zich daarbij niet ten principale over het abstineren afgesproken, Barkhuysen 2004, p. 98.

256. EHRM 27 oktober I994, Kroon v. The Netherlands.

257. HR I6 november I990, NJ I99I, 475.

258. HR 4 november I994, NJ I995, 249. Opmerkelijk genoeg bleek een ambtenaar van de Burgerlijke Stand wél zelf in het rechtstekort te kunnen voorzien, zie Fleuren 2004, p. 358. Vooruitlopend op in te voeren wetgeving voorzag het Hof Den Haag niet veel later ook zelf in dit rechtstekort, Hof Den Haag 12 mei I995, NJ I995, 6or.
} 
den van de vraag of het belang om effectieve rechtsbescherming te bieden zo groot is dat de rechter zelf in het tekort moet voorzien. Dat impliceert dat in de doctrine van de Hoge Raad bewust het risico is aanvaard dat Nederland in Straatsburg wordt veroordeeld, ook al is de Nederlandse rechter uiteindelijk wel bevoegd zelf effectieve rechtsbescherming te bieden.

De zaak Camp (\& Bourimi) betrof het feit dat er in het Nederlandse recht niet voorzien was in mogelijkheid aan de wettiging van een kind terugwerkende kracht te verlenen, zodat het kind erfgenaam van de overleden biologische vader zou kunnen zijn. In casu hadden de ouders van het kind de bedoeling gehad te trouwen toen de vader tijdens de zwangerschap van de vrouw overleed. De Hoge Raad overwoog dat het vaststellen van de gevolgen van een eventuele onverenigbaarheid met artikel 8 jo. I4 EVRM de rechtsvormende taak van de rechter te buiten ging. ${ }^{259} \mathrm{Na}$ een klacht van Camp \& Bourimi in Straatsburg heeft het EHRM betrekkelijk weinig woorden nodig om een schending van artikel 8 jo. I4 EVRM vast te stellen. ${ }^{260}$

In andere zaken is het EHRM coulanter geweest. De zaak Auerbach v. Nederland ten aanzien van een belastingregeling voor bedrijfsauto's vormt een voorbeeld. Het ging om een begunstigende regeling die niet voor Auerbach gold. De Nederlandse rechter constateerde strijd met artikel $\mathrm{I}$ van het $\mathrm{I}^{\mathrm{e}}$ Protocol jo. artikel I4 EVRM maar buiten toepassing laten van de regeling zou Auerbach geen soelaas bieden. De rechter voorzag ook niet zelf in het rechtstekort. Het EHRM beoordeelt de ontvankelijkheid als volgt:

'In these particular circumstances, and bearing in mind that the Court itself has held in various cases that a finding of a violation in itself constituted adequate just satisfaction under Article 4I of the Convention for any non-pecuniary damages suffered, the Court accepts that the Supreme Court's finding of a violation of the applicant's rights under Article I4 of the Convention in conjunction with the cost orders issued in the applicant's favour, and its instruction to the legislator to enact new legislation which has in fact occurred, may be regarded as adequate redress. Consequently, the applicant cannot be regarded as having a continuing legal interest warranting a determination by the Court that his rights under Article I4 of the Convention have been breached. The Court is therefore of the opinion, as regards his complaint under Article I4 of the Convention, that the applicant cannot claim to be a victim within the meaning of Article 34 of the Convention. ${ }^{261}$

Uit het oordeel dat Auerbach geen slachtoffer is in de zin van artikel 34 EVRM, blijkt dat het belang van effectieve rechtsbescherming niet zodanig was dat de nationale rechter zelf in het rechtstekort had moeten voorzien om een veroordeling in Straatsburg te ontlopen. ${ }^{262}$ In dit geval zien we bovendien beide hierboven genoemde

259. HR 24 februari $1995, \mathrm{NJ} 1995,468$.

260. EHRM 3 oktober 2000, Camp \& Bourimi v. The Netherlands.

26r. EHRM 29 januari 2002, Auerbach v. The Netherlands (admiss.); vgl ook EHRM 29 januari 2002 (admiss.), Arends v. The Netherlands.

262. Om die reden is er wel kritiek op deze uitspraak gekomen, noot Barkhuysen in NJCM-bulletin 2002, p. 1027 . 
elementen - het signaal aan de wetgever en de genoegdoening voor de rechthebbende - terug. ${ }^{263}$ Het EHRM heeft bij een oordeel in een andere zaak meer expliciet overwogen dat het bieden van effectieve rechtsbescherming aan de wetgever mag worden overgelaten, gezien het belang van 'legal certainty'. Aan laatstgenoemd belang lijkt onder omstandigheden het belang van het individu om effectieve rechtsbescherming te krijgen ten achter gesteld te kunnen worden. ${ }^{264}$

Het is opmerkelijk dat het EHRM in de zaak Auerbach over een 'instruction' van de rechter aan de wetgever spreekt. De Nederlandse rechter mist immers de bevoegdheid de wetgever opdrachten geven, gezien het eerder behandelde Waterpakt-arrest van de Hoge Raad. ${ }^{265} \mathrm{Nu}$ is de term 'instruction' ook zo op te vatten dat de rechter constateert dat er een rechtstekort is en dat de wetgever de aangewezen instantie is om daarin te voorzien. Dat is geen opdracht, maar eerder 'onderricht'. In het verlengde daarvan is het ook mogelijk dat de Nederlandse rechter aan dat 'onderricht' een termijn verbindt, niet in de zin dat hij een opdracht geeft die binnen die termijn moet zijn uitgevoerd, maar in de zin dat de rechter kenbaar maakt dat hij na ommekomst van die termijn zelf rechtsbescherming zal bieden door in het rechtstekort te voorzien. Daarmee gaat de rechter zijn bevoegdheid niet te buiten. Overigens zij gezegd dat het EHRM zichzelf onder omstandigheden wel bevoegd acht een nationale wetgever een opdracht te geven. ${ }^{266}$

Dat brengt ons op de verschillen tussen geschetste zaken. Auerbach zal in Straatsburg niet als een wezenlijke casus zijn beschouwd. ${ }^{267}$ Er was bijvoorbeeld geen sprake van onderscheid op grond van geslacht, waarvoor zeer gewichtige redenen ('very weighty reasons') nodig zijn. Bovendien kon de strijd met artikel I4 jo. artikel I van het $\mathrm{I}^{\mathrm{e}}$ Protocol ook worden opgeheven door ook anderen dan Auerbach van de begunstigende regeling uit te sluiten. In de zaak Kroon is het ontbreken van de mogelijkheid voor de moeder om het vaderschap te ontkennen - ook los van artikel I4 EVRM - in strijd met de positieve verplichtingen op grond van artikel 8 EVRM. De oplossing kan zeker niet gevonden worden door ook aan de vader de mogelijkheid te ontnemen om het vaderschap te ontkennen. Camp \& Bourimi is een vrij bijzonder, maar tegelijkertijd ook schrijnend geval, waarin de Hoge Raad bovendien geen oordeel over de strijdigheid met het EVRM had gegeven.

263. Zie hieronder; vgl. echter EHRM I2 december 2006, Burden \& Burden v. United Kingdom t.a.v. de Declaration of incompatibility onder vigeur van de HRA in het Verenigd Koninkrijk, daarover Verhey 2007, 28-4I.

264. EHRM I6 maart 2000, Walden v. Liechtenstein (admiss. decision).

265. Zie paragraaf 2.I. Hierbij moet wel worden opgemerkt dat de de Auerbach-zaak vóór de Waterpakt-zaak speelde.

266. Zie EHRM II september 2007, L. v. Lithuania. In deze zaak inzake geslachtsveranderingen overwoog het Hof dat 'the respondent State (...) is to pass the required subsidiary legislation (...) on gender reassignment of transsexuals, within three months of the present judgment becoming final'. Deze zaak heeft in zoverre een uitzonderlijk karakter dat de wet in Litouwen zelf de rechten van transseksuelen al vast had gelegd maar de noodzakelijke nadere uitwerking in de wet op zich liet wachten.

267. Thomassen spreekt in het verlengde van Auerbach van zaken, die niet veel met mensenrechten te maken hebben, zie 'Terugblik op Straatsburg, Interview met W.M.E Thomassen, voormalig Nederlandse rechter in het EHRM', NJCM-bulletin (55 jaar EVRM) 2006. 
Een andere interessante zaak in dit verband is Van Raalte v. Nederland. ${ }^{268}$ Hier ging het om een kinderloze ongehuwde man van boven de 45 die, anders dan kinderloze ongehuwde vrouwen ouder dan 45 jaar, premie op grond van de Kinderbijslagwet moest betalen. Volgens de Hoge Raad was het onderscheid tussen mannen en vrouwen niet geheel van redelijkheid gespeend. Van een schending van artikel I4 jo. artikel I van het $\mathrm{I}^{\mathrm{e}}$ Protocol EVRM was volgens hem dan ook geen sprake. Het Hof in Straatsburg constateerde echter wel een schending. Men kan zich de vraag stellen hoe het EHRM in de Van Raalte zaak geoordeeld zou hebben indien de Nederlandse rechter wél had vastgesteld dat er strijd met het EVRM was, terwijl de wetgever al stappen had genomen om het onderscheid op te heffen. Zou het EHRM dan de redenering gevolgd kunnen hebben dat Van Raalte zelfs geen slachtoffer was? Tegen een dergelijke 'Auerbach redenering' pleit dat het EHRM een onderscheid naar geslacht zwaar op pleegt te nemen. Ervoor pleit mogelijkerwijs dat het onderscheid ook weggenomen kon worden - en door de wetgever weggenomen werd ${ }^{269}$ - door de andere sekse even ongunstig te gaan behandelen. Een aanwijzing zou kunnen zijn dat het EHRM Van Raalte geen schadevergoeding toekent. De vaststelling van het EHRM dat het EHRM geschonden is, is voor hem een voldoende (immateriële) schadevergoeding.

Concluderen we dat de rechter ons inziens in elk geval zo ver mogelijk dient te gaan. Ook als hij aan de horizon de grenzen van zijn rechtsvormende taak ziet opdoemen, zal hij wel degelijk eerst moeten stellen of er sprake is van een een ieder verbindende bepaling en of het wettelijk voorschrift daarmee strijdt. Dan komen de vraag of het buiten toepassing laten in het rechtstekort kan voorzien en de vraag naar de grenzen van de rechtsvormende taak. Daarbij zal hij er maar in beperkte mate op kunnen vertrouwen dat ook het EHRM er oog voor heeft dat in bepaalde gevallen de wetgever de aangewezen instantie is om aan de verdragsverplichtingen te voldoen. Is er sprake van 'suspect qualifications' of van belangrijke positieve verplichtingen dan zal de rechter het belang van effectieve rechtsbescherming voor de rechthebbende een relatief groot gewicht moeten geven om aan de verdragsverplichtingen te voldoen. Een uitzondering geldt uiteraard voor de gevallen waarin de rechter de absolute grens van zijn rechtsvormende taak bereikt. Hij kan bijvoorbeeld niet uit eigen hoofde gedragingen strafbaar stellen.

\section{$4 \quad$ Meerwaarde, samenloop en botsing}

De Nederlandse rechter kan een maatregel van de overheid toetsen aan of interpreteren in het licht van zowel de een ieder verbindende bepalingen van het EVRM en de daarbij behorende protocollen als de grondrechtsbepalingen van de Grondwet, waarbij in het laatste geval uiteraard rekening dient te worden gehouden met het toetsingsverbod. In paragraaf 2 is de bescherming geschetst die de Nederlandse rechter kan geven op grond van de Grondwet; in paragraaf 3 is de bescherming die

268. EHRM 2I februari I997, Van Raalte v. The Netherlands.

269. De vrijstelling voor ongehuwde oudere vrouwen was per I januari 1989 afgeschaft. 
de rechter op grond van het EVRM kan bieden uiteengezet. In dit hoofdstuk wordt de geschetste vergelijking op een aantal punten uitgewerkt en geëxpliciteerd.

\section{I Enkelvoudige bescherming}

In bepaalde gevallen zal alleen een beroep op het EVRM mogelijk zijn. Sommige grondrechten zijn niet (bewegingsvrijheid, recht op leven ${ }^{270}$ ) of slechts zeer ten dele (recht op een eerlijk proces) in de Grondwet vastgelegd. Sommige grondrechten in het EVRM hebben van meet af aan een ruimere reikwijdte dan het vergelijkbare grondrecht in de Grondwet. Reclame valt bijvoorbeeld wel onder artikel ro EVRM, maar artikel 7 lid 4 Grondwet zondert handelsreclame uitdrukkelijk uit van bescherming.

Er zijn ook rechten die alleen in de Grondwet zijn vastgelegd. Men denke aan het (impliciete) verbod om Nederlanders uit te zetten (artikel 2 lid 2 Grondwet) en aan de plicht van de overheid het bijzonder (lager) onderwijs op dezelfde voet te bekostigen als het openbaar (lager) onderwijs (artikel 23 lid 7 Grondwet) Laatstgenoemde norm kan ook niet uit de jurisprudentie van het EHRM worden afgeleid. Er bestaat op grond van artikel 2, Eerste protocol wél de vrijheid om scholen met een religieus of levensbeschouwelijk karakter op te richten ${ }^{27 \mathrm{I}}$ maar daaraan is niet de verplichting voor de overheid gekoppeld om dat onderwijs ook te bekostigen. ${ }^{272}$

\subsection{Overeenkomst en verschil in interpretatie reikwijdte}

Ligt een grondrecht zowel in de Grondwet als in het EVRM vast, dan zou de interpretatie van de reikwijdte in de jurisprudentie nog kunnen verschillen. Gezien het feit dat het EVRM in de Nederlandse rechtspraak een overheersende rol speelt en het verdrag ook door zijn dynamiek de Grondwet in betekenis heeft overvleugeld, blijkt dat niet of nauwelijks. Eerder is het omgekeerde het geval, namelijk dat de interpretatie van de reikwijdte van de Grondwetsbepaling tot op zekere hoogte aansluit bij de interpretatie van de vergelijkbare bepaling in het EVRM. Wij noemen het recht op bescherming van de persoonlijke levenssfeer (artikel Io Grondwet) respectievelijk het recht op respect voor het privé leven (artikel 8 EVRM). ${ }^{273}$ Men zou hier kunnen spreken van verdragsconforme interpretatie van de Grondwet. Ook in andere gevallen is het moeilijk nog een duidelijk onderscheid te maken tussen de uitleg door de rechter van een bepaling van het EVRM respectievelijk de Grondwet, bijvoorbeeld bij de vaststelling van de reikwijdte van de vrijheid van godsdienst.

270. De Grondwet legt in artikel II4 overigens wel een verbod op de doodstraf vast.

27I. O.a. EHRM 7 december 1976, Kjeld, Busk Madsen en Pedersen v. Denmark.

272. Zie Vande Lanotte \& Haeck 2004b, p. 432 voor een overzicht van rapporten van de ECieRM, zie ook EVRM R\&C, losbl. 2.4.2.

273. HR 9 januari I 987 , NJ I987, 928 (Edamse bijstandsvrouw). 
Wel heeft de Nederlandse rechter soms de neiging om de reikwijdte van een grondwettelijk grondrecht beperkt uit te leggen, omdat er anders een probleem met de clausulering ontstaat. De AGRvS achtte het vereiste van een vergunning voor een drukkerij op grond van het Hinderbesluit geen beperking de drukpersvrijheid ex artikel 7 Grondwet, ${ }^{274}$ omdat het Hinderbesluit noch tot doel, noch tot effect heeft het oprichten van drukkerijen te beletten. Deze uitspraak heeft zowel trekken van de (verworpen) leer van de algemene beperkingen als van de redelijke uitleg van grondrechten. Zou het vereiste van een vergunning wel een beperking zijn geweest, dan zou deze in strijd zijn geweest met het verbod van voorafgaand verlof (artikel 7 lid I Grondwet). Volgens de Afdeling is het vereiste wél een inmenging in de in artikel Io EVRM vastgelegde vrijheid, zij het dat deze op grond van het tweede lid van artikel Io geoorloofd is.

Het vrij strikte grondwettelijke vereiste van een formeel-wettelijke grondslag voor een beperking, zal de rechter eveneens tot een enigszins restrictieve interpretatie van de reikwijdte van een grondwettelijk grondrecht kunnen brengen. Een meer algemene regeling, die omwille van de brandveiligheid ook voor een kerkgebouw een gebruikersvergunning eiste, werd door de ABRvS niet als een beperking van de grondwettelijke godsdienstvrijheid aangemerkt. ${ }^{275}$ Daardoor werd de consequentie vermeden dat een dergelijke beperking in de wet in formele zin zou moeten vastliggen. Onder het regime van 9 lid 2 EVRM doet zich niet hetzelfde probleem voor. Ook indien de beperking binnen de reikwijdte valt, laat de clausulering alle ruimte voor een dergelijke inmenging, zolang die inmenging voorzien is bij wet - in de zin van het EVRM - en noodzakelijk is in een democratische samenleving met het oog op een of meer legitieme doelen.

Het is niet uitgesloten dat deze opstelling van de Nederlandse rechter soms ook invloed heeft op de wijze waarop hij de reikwijdte van bepalingen van het EVRM interpreteert. Zo heeft de Hoge Raad in het verleden geoordeeld dat de verplichting om bij deelname aan het verkeer een helm te dragen voor een tulbanddragende Sikh geen inmenging in de in artikel 9 EVRM vastgelegde vrijheid van godsdienst vormde. Die vrijheid omvatte niet 'de vrijheid zich aan een verkeersvoorschrift te onttrekken'. ${ }^{276}$ Op grond van de Straatsburgse jurisprudentie kan worden geconcludeerd dat de (ook) voor Sikhs geldende verplichting om bij het berijden van een motor een helm te dragen wel degelijk een inmenging in de vrijheid van godsdienst is, die overigens wel voldoet aan de het vereiste van proportionaliteit. ${ }^{277}$

\subsection{Aanvullen/overlappen}

Indien er sprake is van een beperking van een grondrecht dat zowel in EVRM als de Grondwet is vastgelegd en er in casu geen relevant verschil in reikwijdte is, moet allereerst op het toetsingsverbod gelet worden. Dat is in hoofdstuk 2 uitgebreid

274. AGRvS 20 november I992, AB I993, 24I.

275. ABRvS 25 januari 200I, NJCM-bulletin 200I, p. 884 .

276. HR 2I februari 1984 , D\&D I984, p. 668.

277. Zie EHRM II jan 2005, Phull c. France (recev.) t.a.v. de veiligheidscontrole op een vliegveld die een Sikh kan nopen tot het afzetten van zijn tulband; daarin ook de verwijzing naar ECieRM 7992/77, $\mathrm{NJ}$ 1978, II7, waarin de plicht tot dragen van een helm in het geding was. 
uiteengezet zodat hier slechts herhaald hoeft te worden dat de Nederlandse rechter een beperking van een grondrecht, die vastgelegd is in een wet in formele zin, niet mag toetsten aan de Grondwet, dus ook niet aan de grondrechtelijke bepalingen daarvan. Het oordeel over de overeenstemming tussen wet en Grondwet is voorbehouden aan de wetgever zelf.

Lagere regelingen en besluiten van bestuurorganen kunnen door de rechter in beginsel wél aan de Grondwet worden getoetst. In dergelijke gevallen zal de rechter zowel kunnen beoordelen of een maatregel in overeenstemming is met het EVRM als met de Grondwet. Daarbij geldt dat de grondwettelijke toets en de toets op grond van het EVRM elkaar kunnen aanvullen of overlappen.

De sterk materieel getinte proportionaliteitstoets van het EVRM biedt de rechter de mogelijkheid van een inhoudelijke afweging. Hij dient in veel gevallen vast te stellen of een beperking van een grondrecht noodzakelijk is in een democratische samenleving. De Grondwet kent een sterk formeel gekleurd clausuleringssysteem, waarin de vraag naar de - wettelijke - bevoegdheid centraal staat. In dat opzicht vullen beide toetsen elkaar goed aan. Een zogeheten verstoring bijvoorbeeld, een maatregel die bedoeld is om iemand die mogelijkerwijs is betrokken bij de voorbereiding van terroristische activiteiten, van verdere deelname te doen afzien, moet als inmenging in het recht op respect voor het privé leven (artikel 8 EVRM) en beperking van het recht op eerbiediging van de persoonlijke levenssfeer (artikel Io Grondwet) worden aangemerkt. De maatregel kan door de rechter op minstens twee aspecten worden bekeken. Is hij niet disproportioneel ${ }^{278}$ en heeft hij een formeelwettelijke grondslag? ${ }^{279}$

Op dat laatste punt doet zich overigens een zekere mate van overlap voor tussen het EVRM-vereiste van voorzienbaarheid bij wet en de grondwettelijke eis van een specifieke wettelijke grondslag. In beide gevallen dient er een rechtsnorm te bestaan op grond waarvan de beperking - tot op zekere hoogte - voorzien kon worden. Het verschil is uiteraard dat de Grondwet daarbij een grondslag in de formele wet eist.

In de gevallen waarin de Grondwet doelcriteria kent, is ook sprake van een zekere overlap met het EVRM. Zo staat de Grondwet toe dat de wetgever in formele zin de bevoegdheid om beperkingen aan betogingen te stellen delegeert aan bijvoorbeeld de gemeenteraad. Deze bevoegdheid dient dan wel te strekken ter bescherming van de gezondheid, in belang van het verkeer, of ter voorkoming van ongeregeldheden (artikel 9 lid 2 Grondwet). Deze doelcriteria zijn geringer in aantal en specifieker dan die in artikel II lid 2 EVRM. Daar staat tegenover dat de bevoegdheid van de wetgever in formele zin om betogingen te beperken in het geheel geen doelcriteria kent (artikel 9 lid I Grondwet). Eens te meer blijkt dat de buitengewoon sterke positie van de wetgever zich niet alleen in het toetsingsverbod toont maar ook in de clausulering van de grondwettelijke grondrechten.

Eerder is geopperd dat de bepalingen van de Grondwet waarin doelcriteria zijn opgenomen een impliciet vereiste van proportionaliteit kennen. Het zou immers merkwaardig zijn indien bijvoorbeeld een vlotte afwikkeling van het verkeer in de

278. Rb. Amsterdam I december 2005, LJN AU73I4.

279. Rb. Amsterdam 9 maart 2006, LJN AV4I73. 
ogen van de grondwetgever steeds een hoger goed zou zijn dan de uitoefening van het grondrecht van vrijheid van betoging. ${ }^{280}$ Dat noopt de rechter onder omstandigheden tot een afweging. In dat geval overlapt de verdragsrechtelijke eis van proportionaliteit de grondwettelijke noodzaak om een afweging te maken. Hier zij aan toegevoegd dat de Nederlandse rechter maatregelen ten aanzien van betogingen vooral beoordeelt op grond van het EVRM en op grond van de Wet openbare manifestaties, die dezelfde doelcriteria kent als de Grondwet. De Grondwet zelf staat in belangrijke mate buiten spel.

Er is ook sprake van overlap indien de normering in de Grondwet sporen draagt van de jurisprudentie van het EHRM. Zo is in artikel I2 Grondwet de plicht opgenomen na een doorzoeking van een woning te notificeren. Deze notificatieplicht, alsmede de mogelijkheid onder omstandigheden af te zien van notificatie, is mede geïnspireerd door het Klass-arrest van het EHRM. ${ }^{28 \mathrm{I}}$

\subsection{Meerwaarde Grondwet}

De Grondwet biedt op bepaalde punten meer bescherming, zo blijkt al uit het voorgaande. Het vereiste dat beperkingen van grondwettelijke grondrechten moeten zijn vastgelegd in een wet in formele zin of - wanneer de Grondwet delegatie toestaat in elk geval tot een dergelijke wet herleid moeten kunnen worden, geeft de burger op het punt van de bevoegdheid meer bescherming dan de bepalingen uit het EVRM. Het EHRM accepteert immers ook lagere wetgeving en beperkingen die uit het ongeschreven recht voortvloeien, zolang dit recht maar voldoende toegankelijk ('adequately accessible') is en voor de burger voldoende voorzienbaar ('foreseeable') is wat de gevolgen kunnen zijn van zijn handelen. ${ }^{282}$

Wij noemen hier nog drie andere wijzen waarop de Grondwet een meerwaarde biedt. In de eerste plaats kent de Grondwet bepaalde leges speciales, die vrij specifieke eisen stellen aan beperkingen. Zo stelt de Grondwet voor een beperking van het briefgeheim de eis van een rechterlijke last (artikel I 3 lid I Grondwet). Een dergelijke vergaande en categorische eis komen we in artikel 8 EVRM noch in de daarop gebaseerde jurisprudentie ten aanzien van het briefgeheim tegen.

Ook het telefoongeheim (artikel 13 lid 2 Grondwet) is in de Grondwet afzonderlijk vastgelegd en strikter geclausuleerd dan het meer algemene recht op eerbiediging van de persoonlijke levenssfeer (artikel Io Grondwet). Dat betekent onder meer dat het van belang is om de juridische status van zogeheten verkeersgegevens (gegevens omtrent het gebruik van telecommunicatie-apparatuur die niet de inhoud van de communicatie betreffen) te bepalen. Vallen de gegevens betreffende het telefoonverkeer net als de inhoud van de communicatie onder het telefoongeheim, dan geldt in beginsel dezelfde bescherming als die voor de inhoud van het telefoongesprek. Het verzamelen van dergelijke gegevens zal in dat geval aan meer voorwaarden moeten

28o. Zie voor de opvatting van de regering Kamerstukken II I976/77, I3 872, nr. 7, p. 34 .

28I. Kamerstukken II I996/97, 25 442, nr. 3, p. 3. Zie tevens EHRM 6 september I978, Klass e.a. v. Germany.

282. EHRM 26 april I979, NJ I980, I46. Daarover De Meij 2000, p. 5 I. 
voldoen dan wanneer deze gegevens alleen onder de bescherming van het recht op eerbieding van de persoonlijke levenssfeer vallen. ${ }^{283}$

Onder vigeur van het EVRM doet zich hier niet hetzelfde probleem voor. Het recht op respect voor de correspondentie staat in artikel 8 EVRM gezusterlijk naast het recht op respect voor het privé leven. De verkeersgegevens vallen daarom net als het telefoongeheim in enge zin binnen de reikwijdte van artikel 8 EVRM. ${ }^{284}$ Zoals gezegd kan bij de afweging of een beperking is toegestaan wel weer rekening worden gehouden met het antwoord op de vraag hoe ingrijpend een inmenging is. Op dat moment kan dus ook onder vigeur van artikel 8 EVRM eventueel onderscheid gemaakt worden tussen een maatregel van de overheid die alleen ziet op de verkeersgegevens en een maatregel die de inhoud van de telefoongesprekken zelf betreft.

Ten overvloede zij hier gezegd dat de interpretatie van de reikwijdte van het grondwettelijke telefoongeheim in de eerste plaats is voorbehouden aan de wetgever. Indien hij een bepaald regime schept voor verkeersgegevens heeft de rechter niet de bevoegdheid om te beoordelen of dat voldoet aan de grondwettelijke eisen. De memorie van toelichting bij het huidige wetsvoorstel tot implementatie van richtlijn 2006/24/EG (Wet bewaarplicht telecommunicatiegegevens) noemt alleen artikel Io Grondwet - en niet artikel I 3 lid 2 Grondwet. ${ }^{285}$

In de tweede plaats kent de Grondwet in artikel 7 Grondwet een categorisch verbod van voorafgaand verlof voor het openbaren van gedachten en gevoelens door middel van de drukpers. Daarin ligt in de eerste plaats een absoluut verbod van voorafgaande inhoudelijke controle vast. Eenzelfde verbod geldt overigens naast de pers ook voor andere communicatiemiddelen dan de omroep (artikel 7 lid 3 Grondwet). ${ }^{286}$ Een dergelijk categorisch verbod treffen we niet in het EVRM aan noch in de jurisprudentie van het EVRM, ook al neemt het EHRM bepaalde vormen van 'prior restraint' extra hoog op. ${ }^{287}$ Het verbod van voorafgaand verlof in artikel 7 lid I Grondwet ziet overigens ook op maatregelen als een vergunningsystemen voor boekhandels en bibliotheken dat los staat van de inhoud van genoemde publicaties. De rechter heeft in het verleden dan ook zulke in lagere regelgeving vervatte beperkingen in strijd met de Grondwet geoordeeld. ${ }^{288}$ Dergelijke vergunningstelsels hoeven daarentegen niet per se in strijd te zijn met artikel Io EVRM.

283. Deze discussie werd overigens gevoerd in het kader van een mogelijke wijziging van artikel $\mathrm{I}_{3}$ Grondwet. Deze wijziging zou tegemoet dienen te komen aan de technische ontwikkelingen. De bepaling doet immers nogal verouderd aan nu alleen brief, telefoon en telegraaf genoemd worden. Zie o.a. Commissie-Franken 2000, p. I6o en het regeringsstandpunt, Kamerstukken II 2000/0I, 27 46o, nr. I, p. 27. Zie ook Asscher 2002.

284. EHRM 2 augustus I984, Malone v. United Kingdom.

285. Kamerstukken II 2006/07, 3I I45, nr. 3, p. 25.

286. Ten aanzien van de omroep (artikel 7 lid 2 Grondwet) is voorafgaand toezicht op een concrete uitzending niet toegestaan, maar een vergunningstelsel dat inhoudelijke criteria kent wel, zie De Meij 2000, p. I79 e.v.

287. EHRM 26 november I99I (Spycatcher), 'most careful scrutiny on the part of the Court'.

288. HR 22 maart ig6o, NJ I960, 274 resp. HR 29 november ig6o, NJ I96I, 206. Een vergunningenstelsel voor journalisten kan overigens ook in strijd geacht worden met het verbod van voorafgaand verlof, zoals vastgelegd in artikel 7 lid I Grondwet. Zie De Meij 2000, p. 96. 
In de derde plaats heeft de Hoge Raad op grond van de Grondwet bepaalde leerstukken ontwikkeld die een specifieke toets mogelijk maken. Het duidelijkste voorbeeld is de verspreidingjurisprudentie, die grenzen stelt aan de bevoegdheden van in het bijzonder de gemeentelijke overheid om de verspreiding van drukwerk te regelen, zoals uiteengezet in paragraaf $2 .{ }^{289}$ In deze jurisprudentie wordt voor ieder zogeheten zelfstandig verspreidingsmiddel de eis gesteld dat een regeling ruimte laat voor gebruik van enige betekenis. Dat kan onder omstandigheden meer bescherming bieden dan artikel Io EVRM, omdat de jurisprudentie van het EHRM soms akkoord lijkt te gaan met een vergaande beperking voor een bepaalde wijze van verspreiden indien er tenminste de mogelijkheid blijft bestaan op een andere wijze te verspreiden. ${ }^{290}$

Indien de Grondwet meer bescherming biedt dan het EVRM is dat in beginsel geen enkel probleem. Artikel 53 EVRM laat immers uitdrukkelijk de mogelijkheid open dat het nationale recht meer bescherming biedt. De constatering dat een beperking van een grondrecht onder vigeur van het EVRM is toegestaan, wil dus niet zeggen dat de verder gaande grondwettelijke eisen geen betekenis meer hebben. Zo mag het gebod om ook de Grondwet aan ieder verbindende verdragsbepalingen te toetsen (artikel 94 Grondwet) niet worden uitgelegd.

Het idee dat een verdergaande grondrechtelijke bescherming op grond van nationaal recht altijd geoorloofd is, nu het verdrag een minimumnorm bevat, dient echter genuanceerd te worden, gezien ook de opkomst van de positieve verplichtingen. Deze kunnen immers ook de verplichting om een grondrecht te beperken met zich mee brengen. In dat geval vloeit uit het EVRM niet alleen een minimum-norm voort maar ook een maximum-norm. Beide normen samen zorgen voor een bepaalde bandbreedte, waarbinnen de nationaal geboden bescherming zich moet bewegen.

\subsection{Conforme interpretatie}

Er zijn ook situaties waarin de rechter niet of nauwelijks expliciet onderscheid maakt of hoeft te maken tussen de betekenis van de grondwettelijke bescherming en de verdragsrechtelijke bescherming van een grondrecht. Dat kan zich voordoen bij (conforme) interpretatie van een wettelijke norm. Indien de rechter bijvoorbeeld het belang van de vrijheid van godsdienst mee laat wegen bij de interpretatie van een rechtsnorm, hoeft het niet duidelijk te zijn of hij zich laat leiden door het EVRM, de Grondwet, door beide, of zelfs door geen van beide, maar bijvoorbeeld door een rechtsbeginsel dat het grondrechtelijke belang tot uitdrukking brengt. Sommige arresten van de Hoge Raad, waarin wel het belang van bepaalde grondrechtelijke vrijheden wordt genoemd, maar waarin niet expliciet verwezen wordt naar het EVRM, kunnen dan ook alleen als een vorm van verdragsconforme interpretatie

289. De in de vorige alinea genoemde beoordeling van een vergunningstelsel voor boekhandels en bibliotheken is overigens ook als onderdeel van deze jurisprudentie te begrijpen.

290. Vgl. EHRM Io juli 2003, Murphy v. Ireland, waarin het EHRM zelfs een verbod voor een heel medium accepteert omdat er nog andere media beschikbaar zijn. Daarbij ging het overigens wel over een vorm van (ideële) reclame. 
worden beschouwd omdat de Hoge Raad daar mede aanhaakt bij belangrijke onderscheidingen uit de rechtspraak van het EHRM zoals die tussen bijdragen aan het maatschappelijke debat en andere uitlatingen. ${ }^{291}$

Verdrag en Grondwet hoeven evenmin expliciet genoemd te worden indien de rechter bepaalde grondrechtelijke belangen dient af te wegen, bijvoorbeeld indien hij het belang van de persvrijheid en van de privacy moet afwegen om vast te stellen of een publicatie publicatie onrechtmatig is. Toch zien we ook hier dat de noodzakelijkheidstoets uit het tweede lid van artikel 8 en ro EVRM het beoordelingskader is gaan vormen en dat de Hoge Raad in de ontwikkeling van de jurisprudentie ook meer expliciet verwezen heeft naar artikel io EVRM en de daarop gebaseerde jurisprudentie. ${ }^{292}$ Uit beide voorbeelden mag meer in het algemeen worden afgeleid dat de verdragsconforme interpretatie in veel gevallen belangrijker is dan de grondwetsconforme interpretatie.

\subsection{Strijd tussen EVRM en op de Grondwet gebaseerde verplichtingen tot beperking?}

Grondwettelijke onthoudingsplichten en verdragsrechtelijke onthoudingsplichten zullen elkaar in beginsel slechts versterken. Strijd tussen EVRM en Grondwet zal zich eerder kunnen voordoen indien het EVRM of de Grondwet juist een beperking vastlegt of daartoe verplicht. Eerst onderzoeken we de mogelijkheid dat een door de Grondwet voorgeschreven beperking 'botst' met het EVRM. Daarna komt de omgekeerde figuur aan bod: de mogelijkheid dat een door het EVRM voorgeschreven beperking 'botst' met de Grondwet.

Indien de Grondwet positieve verplichtingen bij klassieke grondrechten vastlegt, is het de wetgever die bevoegd is om de nadere uitwerking voor zijn rekening te nemen. Hij zal er steeds voor kunnen en moeten zorgen dat deze uitwerking niet in strijd komt met de bepalingen van het EVRM. Strijd tussen Grondwet en EVRM doet zich hier dus niet voor. De verplichtingen die uit de sociale grondrechtsbepalingen in de Grondwet voortvloeien zijn over het algemeen zo weinig concreet dat het voor de wetgever - of meer in het algemeen: de overheid - eveneens mogelijk zal zijn aan deze verplichtingen te voldoen zonder in strijd te komen met het EVRM.

Bij uitzondering legt de Grondwet zelf ook bepaalde beperkingen van grondrechten vast. Zo sloot artikel 54 lid 2 sub b Grondwet tot voor kort ${ }^{293}$ van het kiesrecht uit 'hij die krachtens onherroepelijke rechterlijke uitspraak wegens een geestelijke stoornis onbekwaam is rechtshandelingen te verrichten'. Deze bepaling is voor de rechter aangevochten met een beroep op het IVBPR. De Afdeling bestuursrechtspraak van de Raad van State oordeelde dat 'de uitsluiting van degenen die krachtens een onherroepelijke rechterlijke uitspraak wegens een geestelijke stoornis onbekwaam zijn rechtshandelingen te verrichten, in zijn algemeenheid niet als een onredelijke beperking, als bedoeld in artikel 25, aanhef en onder b, van het IVBPR kan

29I. HR 9 januari 200I, NJ 200I, 203; vgl. ook bijv. HR I5 april 2003, NJ 2003, 334.

292. Zie Schuijt 2008.

293. Zie de Wet van 27 juni 2008, Stb. 2008, 272. 
worden aangemerkt', maar dat 'een dergelijke uitsluiting in een concreet geval tot een uitkomst kan leiden die wel als zodanig moet worden beschouwd'. De Afdeling voegde daaraan toe: 'De wijze waarop moet worden vastgesteld of daarvan sprake is en, zo ja, hoe de strijdigheid met artikel 25, eerste lid, aanhef en onder b, van het IVBPR kan worden weggenomen en aan welk orgaan terzake bevoegdheid moet worden toegekend, vergt evenwel - mede gelet op de maatschappelijke ontwikkelingen ten aanzien van de bescherming van meerderjarigen die als gevolg van een geestelijke stoornis, al dan niet met tussenpozen, niet in staat zijn hun belangen behoorlijk waar te nemen of daarin bemoeilijkt worden - rechtspolitieke keuzes die niet binnen de rechtsvormende taak van de rechter vallen maar door de wetgever zullen moeten worden gemaakt.' De Afdeling bood dus geen effectieve rechtsbescherming in het concrete geval. ${ }^{294}$

Dit voorbeeld ziet weliswaar op de verhouding tussen Grondwet en IVBPR, maar het is niet onaannemelijk dat deze grondwettelijke beperking ook in strijd is met artikel $3, \mathrm{I}^{\mathrm{e}}$ Protocol EVRM. ${ }^{295}$ Ook dan is de verhouding tussen beide normen in theorie duidelijk. De rechter laat wettelijke voorschriften, waaronder de Grondwet, buiten toepassing indien de toepassing in strijd zou zijn met een een ieder verbindende verdragsbepaling (artikel 94 Grondwet). Uit de uitspraak van de Afdeling blijkt overigens dat de rechter in casu terughoudend optreedt, en het liever aan de (Grond)wetgever zelf overlaat om te voorzien in het rechtstekort. Zoals gezegd is de Grondwet inmiddels aangepast.

\subsection{Strijd tussen Grondwet en op het EVRM gebaseerde verplichtingen tot beperking?}

De tweede mogelijkheid van strijd is dat het EVRM of de daarop gebaseerde jurisprudentie bepaalde beperkingen eist en de Grondwet zich daartegen verzet.

$\mathrm{Nu}$ zijn er in het EVRM veeleer mogelijkheden van beperking vastgelegd dan verplichtingen om bepaalde grondrechten te beperken. Artikel I7 EVRM, de misbruik-van-grondrecht bepaling, zou men als een tussenvorm kunnen betitelen. Het feit dat bepaalde, tegen de verdragsrechten gerichte, activiteiten buiten de reikwijdte van onder meer de vrijheid van meningsuiting en de vrijheid van vereniging vallen, houdt strikt logisch geredeneerd nog geen verplichting in dergelijke activiteiten te verbieden, maar komt daar wel dicht bij in de buurt. Hier doen zich overigens geen principiële problemen voor nu de Nederlandse wetgever dergelijke activiteiten strafbaar kan stellen. Strijd met de Grondwet zou pas ontstaan indien men uit artikel I7 EVRM af zou leiden dat staten de verplichting hebben bij dergelijke activiteiten een beroep op de betreffende nationale grondrechten zonder meer uit te sluiten (wat zou kunnen door zelf ook een misbruik van grondrecht bepaling in te voeren). Voor een dergelijke uitleg bestaan echter geen aanwijzingen.

294. ABRvS, 29 oktober 2003, AB 2003, 463.

295. Vgl. EHRM 6 oktober 2005 (GC), Hirst v. United Kingdom. 
De jurisprudentie van het EHRM kan wel de positieve verplichting voor een staat meebrengen om een grondrecht te beperken. Hier interesseert ons in het bijzonder de mogelijkheid, dat positieve verplichtingen op grond van het EVRM de grondwettelijke bescherming van grondrechten zouden kunnen doorkruisen. In theorie is dat niet uitgesloten. Het zal dan moeten gaan om een grondwetsbepaling die de formele wetgever niet de bevoegdheid geeft tot beperking, omdat anders altijd door de wetgever aan de positieve verplichting kan worden voldaan.

Daarom zou men - op het eerste gezicht - kunnen denken aan het absoluut geformuleerde verbod van voorafgaand verlof in artikel 7 Grondwet. Zou men dat zo uitleggen dat de rechter nooit een publicatieverbod kan opleggen voorafgaand aan een publicatie, dan zou dat mogelijkerwijs problemen opleveren bij de bescherming van het recht op respect voor het privé leven. Na publicatie is de inbreuk op de privacy immers niet goed meer ongedaan te maken. In de rechtspraak is echter van oudsher aanvaard dat artikel 7 Grondwet zich niet verzet tegen een publicatieverbod indien hetgeen gepubliceerd zal worden 'voldoende bepaald' is. ${ }^{296}$ Met enige regelmaat wordt dan ook in kort geding de eis toegewezen dat een bepaald artikel of een bepaalde televisie-uitzending niet of niet in die vorm mag worden gepubliceerd.

Artikel 7 Grondwet verzet zich wél zonder meer tegen een eis om aan de overheid ter inzage te geven hetgeen gepubliceerd gaat worden. ${ }^{297} \mathrm{Om}$ die reden was het dan ook uitgesloten dat de overheid voor publicatie inzage zou kunnen afdwingen in de te vertonen film 'Fitna' van het kamerlid Wilders om het mogelijkerwijs onrechtmatig karakter daarvan vast te stellen. $\mathrm{Nu}$ gaan wij er voorshands niet vanuit dat op grond van het EVRM de positieve verplichting bestaat ervoor te zorgen dat het recht de mogelijkheid biedt in een dergelijk geval vooraf inzage te eisen. Ook op dit punt lijkt er dus geen sprake van een botsing tussen EVRM en Grondwet.

Overigens is het in artikel 7 Grondwet vastgelegde verbod van voorafgaand verlof niet 'notstandsfest'. De Grondwet staat uitdrukkelijk toe dat na het uitroepen van een noodtoestand bepaalde grondrechten als de vrijheid van meningsuiting verdergaand beperkt worden dan de grondrechtsbepaling zelf toestaat (artikel I03 Grondwet).

\subsection{Positieve verplichtingen, rechter en wetgever}

In andere gevallen is er voor de wetgever geen grondwettelijk beletsel om aan een positieve verplichting op grond van het EVRM te voldoen maar zal de rechter op de grenzen van zijn rechtsvormende taak kunnen stuiten. Bestaan positieve verplichtingen uit de strafbaarstelling van bepaalde gedragingen dan vormt de Grondwet op zichzelf geen beletsel voor de wetgever om daaraan te voldoen, maar zal de rechter niet zelf een dergelijke voorziening kunnen bieden. Dat zou trouwens ook in strijd zijn met artikel 7 EVRM - en met het keurig daarmee samenlopende artikel I6 Grondwet.

Gaat het om andere maatregelen die grondrechtelijke vrijheden van derden beperken, dan zal de Grondwet eveneens een formeel-wettelijke basis eisen, terwijl het EVRM een minder vergaande eis stelt. In dat geval zal de wetgever uiteraard weer aan

296. De Meij 2000, p. 28I.

297. Zie G.A.I. Schuijt, Onrechtmatige daad VII. Aantasting eer en goede naam en andere aantasting van de persoon, aantekening 7.3 (online; geraadpleegd op I9 augustus 2008). 
de verplichting kunnen voldoen op een wijze die strookt met de eisen van de Grondwet. Wanneer de wetgever in gebreke is, is het aan de rechter om eventueel effectieve bescherming te bieden. In dat geval is het van belang of een dergelijke rechterlijke beperking van een grondrecht in een zaak tussen twee particulieren wel of niet als horizontale werking wordt aangemerkt. ${ }^{298}$ Is dat het geval dan hoeft de grondwettelijke clausulering niet strikt gevolgd te worden en is het ontbreken van een wettelijke grondslag niet essentieel. Ziet men een dergelijke rechterlijke beperking als verticaal en eist men daarom wel steeds een wettelijke grondslag, dan zal de rechter niet Verdrag en Grondwet beide kunnen volgen. Wel zal hij de grondwettelijke eisen op grond van artikel 94 Grondwet buiten toepassing kunnen laten.

Desondanks zal de rechter, ook al gezien de constitutionele verhouding tussen rechter en wetgever, waarschijnlijk geneigd zijn zich in een dergelijk geval terughoudend op te stellen. In de praktijk hoeft het probleem overigens niet zo heel groot te zijn. Veel procedures tussen particulieren op dit terrein zullen gevoerd worden op grond van onrechtmatige daad (artikel 6:I62 BW) en de Hoge Raad accepteert deze zeer open bepaling als een formeel-wettelijke grondslag die een beperking van een grondwettelijk grondrecht met zich mee mag brengen. ${ }^{299}$

In andere gevallen zal - de letter van - de Grondwet geen bezwaren kennen tegen het bieden van effectieve rechtsbescherming door rechterlijke rechtsvorming. De rechter maakt echter een belangenafweging om vast te stellen of hij zelf een voorziening kan bieden of voorlopig zal wachten op de wetgever. In die belangenafweging komt de traditionele constitutionele verhouding tussen rechter en wetgever naar voren. Het belang om rechtsbescherming te bieden wordt in dat kader meegewogen. Desondanks is daarmee een veroordeling in Straatsburg zeker niet uitgesloten, vooral niet wanneer er sprake is van een substantieel rechtstekort. In bepaalde gevallen is het EHRM coulanter. Het EHRM ziet de uitspraak van de rechter dat het vooralsnog aan de wetgever is om in het rechtstekort te voorzien namelijk als een vorm van 'instruction'. Deze kan meewegen, indien het EHRM beoordeelt of er sprake is van een schending van het verdrag of van een 'slachtoffer' in de zin van artikel 34 EVRM.

Hier past overigens de opmerking dat het EVRM niet een bepaalde verhouding tussen wetgever en rechter voorschrijft. ${ }^{300}$ Ook een staat waarin de rechter de wetgever altoos voorrang geeft, kan in elk geval in theorie aan alle verdragsverplichtingen voldoen indien de wetgever maar alert en vooruitziend genoeg is om steeds de dynamische ontwikkeling van de jurisprudentie van het EHRM in rekening te brengen. In de praktijk zal een grote terughoudendheid van de rechter ten opzichte van de wetgever het risico in zich dragen dat een staat na een klacht in Straatsburg veroordeeld wordt.

298. Zie par. 2.2.

299. HR 5 juni I987,NJ I988, 702 (Goeree).

300. Vgl. bijv. ook de opmerkingen over de 'separation of powers' in EHRM 6 mei 2003 Kleijn a.o. v. The Netherlands. 


\section{$5 \quad$ Slotopmerkingen}

Toen Alkema meer dan 20 jaar geleden een preadvies schreef voor de Vereniging voor de vergelijkende studie van het recht in België en Nederland over de toepassing van het EVRM in Nederland ${ }^{30}$ was de invloed van het EVRM op het Nederlandse recht al buitengemeen groot. Die ontwikkeling heeft zich voortgezet. Rechter en wetgever hebben ervoor hebben gezorgd dat het EVRM en de jurisprudentie van het EHRM binnen de Nederlandse rechtsorde een moeilijk te overschatten invloed hebben gekregen, ${ }^{302}$ die zich op tal van rechtsgebieden doet gevoelen.

De doorwerking van het EVRM en daarop gebaseerde jurisprudentie zorgt er samen met het toetsingsverbod voor dat de bescherming in de Nederlandse rechtsorde geboden door het EVRM zonder meer belangrijker is dan de bescherming geboden door de Grondwet. ${ }^{303}$ Terecht concludeert Verhey dat de grondrechten uit de Grondwet tussen 1983 en 2003 slechts incidenteel een rol hebben gespeeld: zij zijn op veel punten overvleugeld door de fundamentele rechten van het EVRM, die diep in de Nederlandse rechtsorde zijn doorgedrongen. ${ }^{304}$

In de Nederlandse jurisprudentie vormen de Grondwet in het algemeen en de grondrechtsbepalingen daarin in het bijzonder geen sprankelend 'living instrument'. Dat komt in de eerste plaats door het toetsingsverbod, waardoor de wetgever de eerste viool speelt bij de interpretatie van de Grondwet. De constitutionele verhouding tussen wetgever en rechter doet zich overigens op meer punten gevoelen. In het algemeen is de rechter geneigd de wetgever niet voor de voeten te lopen, bijvoorbeeld door snel zelf door rechtsvorming in een rechtstekort te voorzien. Hier is in veel gevallen sprake van rechterlijk beleid. Op andere punten ontbreekt de bevoegdheid. Zo mag de Nederlandse rechter de wetgever geen opdrachten tot wetgeving verstrekken. Dit geldt zowel voor de formele wetgever als voor lagere wetgevers.

Een aantal grondwettelijke meerwaarden als de eis van een specifieke formeel-wettelijke grondslag voor een beperking van veel grondrechten en het categorisch verbod van voorafgaand verlof mogen niet verhullen dat er maar in beperkte mate een grondrechtendynamiek van nationale origine bestaat. De mogelijkheid dat de Nederlandse rechter op grond van het EVRM een grotere bescherming geeft dan de jurisprudentie van het EHRM voorschrijft en op die manier een 'eigen dynamiek' ontwikkelt, is door de Hoge Raad in een belangrijk opzicht onderuit gehaald: de Nederlandse rechter mag alleen wettelijke voorschriften buiten toepassing laten wegens strijd met een bepaling van het EVRM indien de (door de Nederlandse rechter getrouw geconstrueerde) uitleg van het EHRM daartoe noopt.

30I. Alkema i985, p. 3 I.

302. Nog los van de vraag of de implementatie altijd zo goed is gelukt, zie daarvoor Alkema 2005, p. IoII.

303. De Grondwet bepaalt uiteindelijk uiteraard ook de doorwerking van het EVRM en de daarop gebaseerde jurisprudentie.

304. Verhey 2003 , p. 222. 
Ook deze eis van terughoudendheid is tot op zekere hoogte als een gemodificeerde vorm van de traditionele opstelling van de rechter tegenover de wetgever te begrijpen. Deze opstelling kan ertoe leiden dat de door de Nederlandse rechter geboden bescherming tendeert naar wat het EHRM expressis verbis opdraagt. ${ }^{305}$ Daardoor kan het 'nationale maximum' samenvallen met het 'Europese minimum'. Dat zal in het bijzonder het geval zijn indien ook de wetgever zoekt naar het grondrechtelijke minimum. Het hoeft geen betoog dat een dergelijke minimale bescherming een relatief groot risico in zich bergt van een veroordeling door het EHRM.

De traditionele constitutionele plaats van de rechter binnen de trias politica heeft tevens invloed op zijn opvatting over de grenzen van zijn rechtsvormende taak en daarmee op het relatieve belang dat hij hecht aan het zelf geven van effectieve rechtsbescherming. De opstelling van de rechter in dezen komt er soms op neer dat het risco van een veroordeling in Straatsburg op de koop toe moet worden genomen, ook al is de rechter op zichzelf bevoegd om zelf effectieve rechtsbescherming te bieden.

De traditionele constitutionele plaats van de rechter die in de eerste plaats van belang is voor zijn mogelijkheden om bescherming te bieden aan de grondwettelijke grondrechten heeft dus ook invloed op de bescherming die hij op grond van het EVRM biedt. Er is op deze punten, zo men wil, sprake van een samenloop van de gebrekkige bescherming van de grondwettelijke grondrechten enerzijds met de suboptimale bescherming van de grondrechten vastgelegd in het EVRM.

Zou het toetsingsverbod zijn opgeheven, dan zou ons verhaal er anders uit hebben gezien. De betekenis van de Grondwet zou groeien en de rechter zou een andere, soms ook verder gaande bescherming kunnen bieden dan op grond van het EVRM.

Wel passen hier een aantal opmerkingen. De clausulering in de Grondwet wijst steeds de wetgever aan als het competente orgaan om de grondrechten te beperken. De clausulering kent daarentegen maar een beperkt aantal aanknopingspunten om wetten in formele zin inhoudelijk te toetsen. Dat betekent dat de opheffing van het toetsingsverbod alleen een duidelijk effect zal hebben indien de rechter ook een materiële toets uit zal gaan voeren. Dat valt ook te verwachten. In grondwetsbepalingen met doelcriteria ligt naar onze mening nu al een zekere proportionaliteitstoets besloten. Meer in het algemeen blijkt uit het initiatiefwetsvoorstel Halsema dat de rechter geacht wordt te gaan toetsen aan proportionaliteit en subsidiariteit. ${ }^{306}$ In dat geval zal de Nederlands rechter op grond van de Grondwet bijvoorbeeld een striktere proportionaliteitstoets kunnen uitvoeren dan waartoe het EVRM en de daarop gebaseerde jurisprudentie noopt. Het risico van een veroordeling in Straatsburg kan navenant kleiner worden.

Dit alles staat los van het antwoord op de vraag of de opheffing van het toetsingverbod als zodanig ertoe leidt dat de rechter zich ook bevoegd acht op grond van het EVRM meer bescherming te bieden dan het Hof in Straatsburg voorschrijft. Hier zij herhaald dat de terughoudendheid in dezen niet volledig lijkt voort te vloeien uit de

305. Heringa 2003, 276-288.

306. Zie onder meer Kamerstukken I 2006/07, 28 33I, C, p. I3. 
traditionele constitutionele plaats van de rechter maar ook op de uitleg van artikel 93 en 94 Grondwet: de notie dat de interpretatie van het EHRM zich invoegt in de een ieder verbindende bepaling waaraan de Nederlandse rechter mag toetsen.

Ziet men de opheffing van het toetsingsverbod meer in het algemeen als een verschuiving in de verhouding tussen wetgever en rechter, dan zou deze ook gevolgen kunnen hebben voor de afweging die de rechter maakt wanneer hij de vraag beantwoordt of hij zelf effectieve rechtsbescherming moet bieden of zich terughoudend moet opstellen en het woord aan de wetgever dient te laten. Zou hij zijn terughoudendheid in dezen deels laten varen, dan zou ook dat het risico van een veroordeling van Nederland in Straatsburg kunnen verminderen.

Zou de Grondwet een 'living instrument' worden, dan is het overigens niet geheel denkbeeldig dat er vaker spanningen optreden tussen Grondwet en EVRM. De rechter zou onder omstandigheden bijvoorbeeld wetgeving die naar de mening van de wetgever bedoeld is om te voldoen aan positieve verplichtingen op grond van het EVRM, aan de Grondwet kunnen toetsen. Voorts is het niet uitgesloten dat de rechter ook tal van positieve verplichtingen uit de Grondwet afleidt. Indien deze leiden tot beperking van grondrechten van derden, moeten die beperkingen op hun beurt voldoen aan de voorwaarden van het EVRM.

Formeel zou de verhouding tussen Grondwet en verdrag echter niet veranderen. De rechter mag de verdragsbepalingen niet toetsen aan de Grondwet (artikel I2O Grondwet) en bij strijd dient de Grondwet buiten toepassing gelaten te worden (artikel 94 Grondwet). Desondanks kan men zich voorstellen dat een eigen doctrine op het gebied van de bescherming van grondrechten de Nederlandse rechter zelfbewuster zal maken en dat hij deswege ook eerder een dialoog zou kunnen aangaan met het Hof in Straatsburg. ${ }^{307}$

De tegenstander van toetsing zal van dit alles gruwen. De wetgever, het hoogste politieke orgaan, krijgt niet alleen rechterlijk 'toezicht' op grond van onthoudingsplichten en positieve verplichtingen die voortvloeien uit het EVRM, maar ook nog eens op grond van grondwettelijke onthoudingsplichten en positieve verplichtingen. De huidige bandbreedte die op grond van het EVRM bestaat bijvoorbeeld bij het vaststellen van de verhouding tussen het belang van persvrijheid en privacy of tussen persvrijheid en vrijheid van godsdienst wordt dan nog aangevuld met een juridische bandbreedte van nationale origine. Gezien de appreciatiemarge zal een dergelijke bandbreedte van nationale origine eerder smaller dan groter zijn dan de door het EHRM vastgestelde bandbreedte.

De opheffing van het toetsingsverbod betekent echter niet dat de rechter op de stoel van de wetgever hoeft te gaan zitten. De afweging van grondrechtelijke belangen is en blijft voor een deel ook een taak van 'de politiek' en de rechter zal een goed gemotiveerde en uitvoerig bediscussieerde afweging door de wetgever waarschijnlijk niet snel afkeuren. Wetgever en rechter zijn hier niet elkaars tegenstander. Integendeel, zij vullen elkaar aan.

307. Vgl. in deze zin ook Heij, De Lange \& Mevis, NJB 2005 (digitaal) p. 7. 